\title{
Articles
}

\section{Commercializing Marriage: A Proposal for Valuing Women's Work Through Premarital Security Agreements}

\author{
Martha M. Ertman*
}

com-merce . . 1: social intercourse: interchange of ideas, opinions, or sentiments 2: the exchange or buying and selling of commodities on a large scale involving transportation from place to place 3: SEXUAL INTERCOURSE syn see BUSINESS ${ }^{1}$

\section{Introduction}

The dictionary definition of commerce reveals the close, sometimes synonymous, relationship between finance and romance. This linguistic insight is not news to many homemakers who become indigent, or nearly so, upon divorce, despite their years of helping to provide a significantly higher quality of life for their families than they are able to sustain post-

* Assistant Professor, University of Denver College of Law, B.A. Wellesley College, J.D. Northwestern University School of Law. This Article has benefitted considerably from comments during presentations at the 1997 meetings of the Law and Society Association and the Society for the Advancement of Socio-Economics, Columbia University Law School's 1998 Workshop on Economic Theory and the Family, to the faculty of the University of Denver College of Law and also from feedback on a related paper presented at the University of Denver College of Law InterSEXionality Symposium. I am particularly indebted to Jake Barnes, Mary Becker, Cynthia Bowman, Margaret Brinig, Penelope Bryan, Pat Cain, June Carbone, Fred Cheever, Alan Chen, Roberto Corrada, Mary Anne Case, Lloyd Cohen, Nancy Ehrenreich, Ira Ellman, Ann Estin, Anne Ertman, Martha Fineman, Herma Hill Kay, Catherine Kemp, Jennifer Levi, Neil Littlefield, Jean Love, Julie Nice, Terry O'Neill, Twila Perry, Richard Posner, Jane Schacter, Kate Silbaugh, Jeffrey Stake, Cynthia Starnes, and Joan Williams for their valuable comments, the University of Denver for financial support, Marisa Amin, Justin Arnold, Diane Burkhardt, Mike Greenfeig, Kerri Pertcheck, Brandi Pummell, and Lisa Wong for considerable research support, and the Texas Law Review staff for invaluable editing. Finally, credit is due to Julie Nice for lending her ear and sterling intelligence to countless conversations revisiting my ideas.

1. MERRIAM-WEBSTER's COLlegiate DictionaRY 231 (10th ed. 1993). In the words of the Supreme Court, "[C]ommerce, undoubtedly, is traffic, but it is something more: it is intercourse." Gibbons v. Ogden, 22 U.S. (9 Wheat.) 1, 189 (1824). 
divorce. The primary cause of displaced homemaker indigency is simple: The work that homemakers do for their families is not commodified. ${ }^{2}$ Despite this clarity regarding the cause of displaced homemaker indigency, the search for tools to alleviate the problem has proven elusive.

The commodification of primary homemakers' marital contributions has generated extensive scholarly dialogue, ${ }^{3}$ but few have advocated using commercial law to address the economic problems of displaced homemakers upon divorce. ${ }^{4}$ Commercializing marriage makes sense because many of the economic problems divorced women face stem from the undercommodification of their contributions to family wealth, and commercial law is tailored to address these kinds of financial issues (at least more so than family law). Moreover, family law has long been rooted in traditional models of gendered domestic roles that obscure the economic value of homemaking. $^{5}$ Thus, the financial nature of displaced homemakers'

2. Noncommodification of women's domestic labor for their families is, of course, only one factor, albeit an important one, contributing to the economic straits many women suffer upon divorce. Some women may be indigent both during marriage and after divorce; others might experience marginalization from the paid labor force because of systemic barriers to their entry and continued presence in the wage labor force, such as sex discrimination in the form of wage differentials or discriminatory patterns of hiring and promotion, see infra note 6 . Moreover, some homemaking is commodified, particularly when it is contracted out to nonfamily members for (often minimal) wages, see infra note 99 . This Article focuses on the noncommodification of work that homemakers do for their families, and how implementing a commercial debtor-creditor model goes some way toward remedying the financial penalties many homemakers suffer upon divorce. For a review of how various legal doctrines systematically devalue homemaking, see generally Katharine Silbaugh, Turning Labor into Love: Housework and the Law, 91 Nw. U. L. REV. 1 (1996) [hereinafte: Silbaugh, Labor].

3. Jana B. Singer, Husbands, Wives, and Human Capital: Why The Shoe Won't Fit, 31 FAM. L.Q. 119,121 (1997) (describing "the search for firm theoretical grounding for financial obligations that survive divorce" as a "dominant theme of family law scholarship over the past decade").

4. At least two commentators have advocated importing partnership law into divorce. See Jana B. Singer, Alimony and Efficiency: The Gendered Costs and Benefits of the Economic Justification of Alimony, 82 GEO. L.J. 2423, 2454-56 (1994) [hereinafter Singer, Alimony]; Cynthia Starnes, Divorce and the Displaced Homemaker: A Discourse on Playing with Dolls, Partnership Buyouts and Dissociation Under No-Fault, 60 U. CHI. L. REV. 67, 71 (1993) [hereinafter Starnes, Divorce]. Two others have invoked the Uniform Commercial Code to discuss contractual understandings of marriage. See Allen M. Parkman, Reform of the Divorce Provisions of the Marriage Contract, 8 BYU J. PUB. L. 91, 105 (1993) (briefly proposing a "Marriage Code similar to the Uniform Commercial Code"); Carol Weisbrod, The Way We Live Now: A Discussion of Contracts and Domestic Arrangements, 1994 UTAH L. REV. 777, 807-14 (1994) (discussing domestic agreements as legally enforceable contracts under Article 2 of the U.C.C.). Premarital security agreements similarly import business methods of retrieving lost investments when a relationship breaks down, but they also build on the partnership buyout model by providing self-help remedies. These remedies account for primary homemaker contributions to the primary wage earner's stream of income after divorce and counteract the gender hierarchy of marriage with the commercial hierarchy of debtor-creditor relations. See infra subsection $\operatorname{IV}(\mathrm{C})(2)(\mathrm{c})$.

5. See Reva B. Siegel, Home as Work: The First Woman's Rights Claims Concerning Wives' Household Labor, 1850-1880, 103 YALE L.J. 1073, 1077 (1994) [hereinafter Siegel, Home] (noting that nineteenth century earnings statutes "deliberately preserved a husband's common law rights in his wife's household services"); Reva B. Siegel, The Modernization of Marital Status Law: Adjudicating Wives' Rights to Earnings, 1860-1930, 82 GEO. L.J. 2127, 2130-31 (1994) (observing that during the 
problems begs for economic solutions such as those provided by commercial law.

This Article proposes that commercializing marriage might solve some of the financial problems of divorced homemakers. Specifically, I propose the use of security agreements, which I call Premarital Security Agreements ("PSAs") to reveal the debtor/creditor aspect of marriages in which primary homemakers ${ }^{6}$ enable primary wage earners to maximize

early twentieth century courts refused to enforce interspousal contracts that attached monetary value to a wife's labor). Even when family law doctrine has seemed to account for women's property rights in the fruits of their labors, husbands' traditional entitlement to the value of women's work done in the home has survived through a process that Reva Siegel has described as "preservation-throughtransformation." See Reva Siegel, Why Equal Protection No Longer Protects: The Evolving Forms of Status-Enforcing State Action, 49 STAN. L. REV. 1111, 1113 (1997) [hereinafter Siegel, Protection] (defining "preservation-through-transformation" as a process through which law perpetuating unequal status relationships is simultaneously reformed and reinstated).

6. This Article uses the terms "primary homemaker" and "primary wage earner" to reflect the fact that in most marriages both spouses participate in the wage labor market, but not at the same level. In $1987,56 \%$ of women over 16 years of age participated in the labor force, an increase from $52 \%$ in 1981 and $46 \%$ in 1975. See BETH ANNE SHELTON, WOMEN, MEN AND TIME: GENDER DIFFERENCES IN PAID WORK, HOUSEWORK AND LEISURE 35 (1992). In 1996, fully 70\% of married mothers participated to some extent in the wage labor market. See BUREAU OF THE CENSUS, U.S. DEP'T OF COMMERCE, STATISTICAL ABSTRACT OF THE UNITED STATES 404 tbl.631 (117th ed. 1997) [hereinafter CENSUS, STATISTICAL ABSTRACT]. But fewer mothers of young children work in the wage labor force. In 1996, 62.7\% of married mothers of children under 6 years old engaged in wage labor. See id. These statistics suggest that women are very much a part of the paid work force, perhaps making it out of date (or worse) to use feminine pronouns when discussing primary homemakers. However, many of these women participate in the labor force in marginalized ways, as part-time or seasonal employees desiring positions close to home to accommodate childcare and other homemaking needs. See VICTOR R. FUCHS, WOMEN's QUEST FOR ECONOMIC EQUALITY 41 (1988); see also Cynthia Stames, Reflections on Betty Crocker, Soccer Mom, and Divorce: A Message from Detergent Manufacturers, 1997 WIS. L. REV. 285, 292 (noting that a caretaker's “employment may be part-time or sporadic and she is likely to be channeled into the secondary job market where wages are low and opportunities for advancement limited"). But see Kristin McCue \& Manuelita Ureta, Women in the Workplace: Recent Economic Trends, 4 TEX. J. WOMEN \& L. 125, 127 (1995) (suggesting that female participation in the labor force is decreasingly tied to family status and increasingly tied to education). Moreover, even those women who actively participate in the wage labor force do far more housework than their male partners. See ARLIE HOCHSCHILD, THE SECOND SHIFT 8 (1989) (describing a study in which $20 \%$ of heterosexually coupled men shared housework equally, $70 \%$ did between one-half and one-third, and $10 \%$ did less than one-third); Ziarat Hossain \& Jaipaul L. Roopnarine, Division of Household Labor and Child Care in Dual-Earner African-American Families with Infants, 29 SEX ROLES 571, 577 (1993) (indicating that in African-American families with infants and both parents working full-time, fathers spent about $35 \%$ as much time as mothers did in primary care-giving activities). And men still make more than women. See FucHS, supra, at 52 (stating that among white couples, three out of four husbands earned more than their wives, and fully half of the wives earned less than two-thirds of what their husbands earned); BUREAU OF THE CENSUS, U.S. DEP'T OF COMMERCE, MONEY INCOME IN THE UNITED STATES: 1996, at 26-27 tbl.7 (1997) [hereinafter CENSUS, INCOME]; Tamar Lewin, Women Losing Ground to Men in Widening Income Differences, N.Y. TIMES, Sept. 15, 1997, at A1 (describing Bureau of Labor Statistics data that the median weekly earnings of women working full time are "just under $75 \%$ of men's median, down from $77 \%$ four years ago"). In 1996 , women's median income was $\$ 12,815$, compared to men's median income of $\$ 23,834$. This gender gap is less pronounced between men and women of color. See CENSUS, INCOME, supra at 2627 tbl.7. In 1996, African-American women's median income was $\$ 11,772$, compared to $\$ 16,491$ for African-American men, and median income for Hispanic women in 1996 was $\$ 9,484$, compared to 
their earning potential. PSAs would protect the primary homemaker's interest in the repayment of her "loan" to her primary wage-earning spouse by granting her a security interest in fifty percent of all marital property, most importantly the primary wage earner's post-divorce income. ${ }^{7}$ By commodifying the contributions of homemaking to family wealth, PSAs could alleviate the indigency and near-indigency of many displaced homemakers and also increase respect for homemaking. In addition, because the devaluation of homemaking contributes significantly to women's general economic inequality, ${ }^{8}$ PSAs might address the related problem of devalued female work in the market.

$\$ 15,437$ for Hispanic men. See id. Considering the gendered wage gap and the fact that women are likely to do more homemaking than men (regardless of their employment status), this Article observes the convention of using female pronouns to describe primary homemakers, and male pronouns to describe primary wage earners. See, e.g., Starnes, Divorce, supra note 4, at 69 n.3; Joan Williams, Is Coverture Dead? Beyond a New Theory of Alimony, 82 GEO. L.J. 2227, 2229 (1994) [hereinafter Williams, Coverture]. However, PSAs do not require that women be primary caretakers or that men be primary wage eamers. To the contrary, as discussed infra, in section IV(B)(2) and subpart V(B), PSAs could create a social and legal climate in which men would be increasingly likely to be caretakers, women would be increasingly likely to be wage earners, or both men and women would be increasingly likely to equally divide wage-eaming and homemaking tasks. Moreover, any alimony statute that is not gender neutral would likely face a constitutional challenge. See Orr v. Orr, 440 U.S. 268, 283 (1979) (striking down an Alabama statute that required husbands, but not wives, to pay alimony).

7. See Margaret F. Brinig, Property Distribution Physics: The Talisman of Time and Middle Class Law, 31 FAM. L.Q. 93, 95-96 (1997) [hereinafter Brinig, Property] (arguing that the most valuable asset in most marriages is the primary wage earner's post-divorce income). Designating post-divorce income as marital property is a considerable change from the law in many jurisdictions. See 2 HOMER H. ClaRK, JR., THE LAW OF DOMESTIC RELATIONS IN THE UNITED STATES § 16.5, at 202-03 (2d ed. 1987) (describing cases in which courts refused to designate degrees earned during marriage as marital property, and other cases which either hold that increased eamings due to a degree or license are marital property or that the supporting spouse should be compensated under another theory, such as unjust enrichment). Because post-divorce income is often the most important asset, and yet is usually allocated to the primary wage-earning spouse, this Article proposes that at least part of it be designated as marital property to include it in the collateral described in the PSA.

To fully explain PSAs, it is important to distinguish between the debt and the collateral. The debt represents the primary homemaker's contribution to her spouse's income potential through both domestic services and foregone opportunities to develop her own human capital. The debt is calculated using a formula described infra, in notes 15-18 and accompanying text. For further commentary, see also infra section III(A)(2). The collateral, in contrast, secures the debt. If the primary wage earner fails or refuses to pay, the primary homemaker can use the collateral to satisfy the debt.

8. See FuCHS, supra note 6 , at 41 (observing that historically women have been pushed towards the roles of wife, mother, and homemaker, while men have been socialized to be the primary provider). Catharine MacKinnon has powerfully articulated the far-reaching implications of arguments to remunerate homemaking: "Women's work has been minimized . . . . [S]o long as women are excluded from socially powerful activity, whatever activity women do will reinforce their powerlessness, because women are doing it; and so long as women are doing activities considered valueless, women will be valued only for the ways they can be used." CATHARINE A. MACKINNON, TOWARD A FEMINIST THEORY OF THE STATE 80 (1989) [hereinafter MACKINNON, FEMINIST THEORY]; see also Mary Anne C. Case, Disaggregating Gender from Sex and Sexual Orientation: The Effeminate Man in the Law and Feminist Jurisprudence, 105 YALE L.J. 1, 3 (1995) (arguing that feminists should be concerned with mistreatment of effeminate men because such discrimination reflects the devaluation of feninine behavior). 
A conventional security agreement grants a creditor a security interest in a debtor's property to secure repayment of a loan. ${ }^{9}$ In the marital relationship, a PSA would grant the creditor/homemaker a security interest in marital property to secure compensation for services she has performed and her foregone opportunities for market participation. By anticipating future payment for these valuable contributions to family wealth (through sharing the primary wage earner's income until death ends the marriage), the primary homemaker, in effect, extends credit to her spouse.

The credit extended by the primary homemaker would be the value of devoting her primary attention to domestic services. This value can be determined using at least three different calculations: the cost of replacing a homemaker's services with market labor; the lost opportunity costs borne by the homemaker by virtue of devoting her time to homemaking instead of market labor; and econometric models based on economic theory and statistical analysis. ${ }^{10}$ While the lost opportunity cost model is popular among some commentators, ${ }^{11}$ it also has been criticized by feminists for its focus on costs borne by homemakers and failure to account for the benefits primary wage earners enjoy as a result of traditional gendered divisions of domestic labor. ${ }^{12}$ Specifically, primary homemakers make it possible for primary wage earners to achieve "ideal-worker"13 status

9. See U.C.C. § 1-201(37) (1995) (defining security interest); Id. § 9-105(1)(1) (defining security agreement); JAMES J. WHITE \& ROBERT S. SUMMERS, UNIFORM COMMERCIAL CODE § 21-2, at 717 (4th ed. 1995).

10. See Charles C. Fischer, The Valuation of Household Production:Divorce, Wrongful Injury and Death Litigation, 53 AM. J. ECON. \& SOC. 187, 188-92 (1994) (reviewing methodological approaches for valuing household production).

11. See, e.g., Ira Mark Ellman, The Theory of Alimony, 77 CAL. L. REv. 1, 17 (1989) [hereinafter Ellman, Theory] (explaining the popularity of the lost opportunity cost model among commentators and courts).

12. See, e.g., Singer, Alimony, supra note 4, at $2444-47$ (deriding the lost opportunity cost model for failing to account for the benefits enjoyed by the primary wage earner by virtue of being both a parent and an ideal worker); Katharine Silbaugh, Marriage Contracts and the Family Economy, 93 Nw. U. L. REV. (forthcoming Fall 1998) (manuscript at 36-38, on file with the Texas Law Review) [hereinafter Silbaugh, Marriage] (describing "loss-thinking" and "gain-thinking" and suggesting that gain-thinking benefits many women by aggregating their "home labor with their wage labor, asking what the overall contribution of both is to marriage.").

13. Williams, Coverture, supra note 6, at 2229 (defining the "ideal worker" as a full-time working husband with few domestic responsibilities). Of course, the kind of ideal worker one is has class and racial dimensions, given wage disparities based on differential access to particular occupations and professions based on race and class. See id. at 2239-45. Moreover, this paradigm of ideal worker and primary homemaker may itself be based on a white, middle, or upper-middle class template. See Twila L. Perry, Alimony: Race, Privilege and Dependency, 82 GEO. L.J. 2481, 2486 (1994) [hereinafter Perry, Alimony] (critiquing alimony proposals for assuming a "paradigm marriage" that does not apply to many low-income women and women of color). There is less of a wage gap between AfricanAmerican men and women than there is between white men and women. See Dorothy A. Brown, The Marriage Bonus/Penalty in Black and White, 65 U. CIN. L. REV. 787, 795-6 (1997) (describing data revealing that for every dollar a white man earns, a white woman earns 78 cents, an African-American man earns 75 cents, and an African-American woman earns 66 cents). Thus, the arrangement that 
through full-time, year-round participation in wage labor-largely unhindered by child care or other domestic responsibilities. ${ }^{14}$

This Article proposes a formula that accounts for both the primary wage earner's gains and the homemaker's losses due to their specialization in wage and domestic labor. The formula calculates the debt in two stages, determining first the amount of an annual payment and then how long those payments should last. The proposed annual payment is thirty percent of the difference between the spouses' incomes at the time of the divorce. The proposed duration of these payments is half the length of the marriage plus the difference between eighteen and the age of the youngest minor child. The total debt is calculated by multiplying the annual payment by the duration. Mathematically, the formula looks as follows:

$$
\text { (.3(high income - low income)) } \frac{\text { Annual Payment }}{\text { (length of marriage }}+\frac{\text { Duration }}{2}+(18-\text { age of youngest minor child)) }
$$

The thirty percent figure represents the primary homemaker's contributions to family wealth by providing valuable services and foregoing the opportunity to develop her own market potential, ${ }^{15}$ and it is based on the assumption that the lower-earning spouse does more of the homemaking labor. ${ }^{16}$ The annual payment thus reflects how much a primary homemaker contributed to family wealth in a particular year. The durational factor accounts for the primary homemaker's long-term contributions

Williams classifies as the "dominant domestic ecology" may be most common in white, upper-middle class marriages and may have less applicability in lower-income families and families of color. However, redistribution of post-divorce income benefits would still benefit many low-income women and many women of color to the extent that gendered wage differences do exist in low-income families and families of color. PSAs, moreover, could be treated as a setoff to decrease primary homemakers' share of marital debt in order to benefit poor women and many women of color whose spouses do not fit the ideal worker paradigm. See infra subsection $\operatorname{IV}(C)(2)(d)(1)$.

14. See Williams, Coverture, supra note 6, at 2236 (characterizing the paid labor market as structured around an ideal worker with no domestic responsibilities). Unlike the primary homemaker, the ideal worker has the best of both worlds: economic independence and social status by virtue of wage labor, and the noneconomic pleasures of being a parent.

15. See infra section III(A)(2).

16. The lower-earning spouse is usually, though not necessarily, female, see CENSUS, INCOME, supra note 6, at 26-27 tbl.7, and women do more housework than their male partners. See HOCHSCHILD, supra note 6, at 216-38, 271-78. Some economists suggest a correlation between these two patterns. See, e.g., GARY S. BECKER, A TREATISE ON THE FAMILY 56 (enlarged ed. 1991) ("[T]he housework responsibilities of married women may be the source of much of the difference in earnings and in job segregation between men and women."); RICHARD A. POSNER, ECONOMIC ANALYSIS OF LAW 157 (5th ed. 1998) [hereinafter POSNER, ECONOMIC] (suggesting that "to the extent that sex discrimination in the labor market depresses women's market earnings relative to men's it makes household work relatively more attractive to the wife than to the husband"). For a study suggesting various reasons for wage differentials between male and female lawyers, see Cathlin Donnell et al., Gender Penalties: The Results of the Careers and Compensation Study (1998) (unpublished manuscript at 79-82, on file with the Texas Law Review). 
to family wealth. The length-of-marriage provision (length of marriage divided by 2) recognizes predivorce homemaking contributions and protects the interests of homemakers divorced after long marriages when the children have grown up and left home (or will do so soon). The second part of the durational calculation (18 minus age of youngest minor child), in contrast, accounts for the post-divorce contributions a primary homemaker makes to the primary wage earner's stream of income. If, for example, a marriage ends after five years and one child, the primary homemaker likely has custody of the child ${ }^{17}$ and thus continues to perform parenting services that enable the primary wage earner's status as an ideal worker to continue even after divorce. This value is independent of child support. Unlike child support payments, the debt secured by the PSA represents a reimbursement for the primary caregiver's contributions to the ideal worker's income and other family wealth. Child support payments, in contrast, fulfill a divorced parent's duty to share the expenses of raising a child with his or her ex-spouse. ${ }^{18}$ The formula and its application are discussed further in section III(A)(2).

According to this commercial understanding of marriage, the primary homemaker extends credit in the form of domestic services to the primary wage earner. If the marriage remains intact, the primary homemaker/creditor gets a return on her loan by sharing in the primary wage earner's earnings. However, if the marriage ends, the wage earner's debt goes unpaid, and the homemaker/creditor should be able to collect on the loan just as any other creditor can collect an unpaid debt. The formula proposed here determines the amount of the debt, and the PSA secures the debt, enabling the primary homemaker to use self-help methods such as repossession to obtain repayment. If the primary wage earner's postdivorce income is part of the collateral securing the debt, then the homemaker/creditor could garnish a percentage of that income. ${ }^{19}$

17. See Lenore J. WeItzman, THE Divorce Revolution: THE UneXPeCted SOCial AND ECONOMIC CONSEQUENCES FOR WOMEN AND CHILDREN IN AMERICA 216 (1985).

18. A jurisdiction adopting PSAs could, of course, provide that a primary wage earner's total payments of child support and the debt secured by the PSA should not exceed a percentage of his total income.

19. Wage garnishments are already available in family law for child support or maintenance. See, e.g., CoLO. REV. STAT. § 14-14-111.5 (1998) (establishing a garnishment procedure, termed "income assignment" for the collection of child support and maintenance); see also Herma Hill Kay, Beyond NoFault: New Directions in Divorce Reform, in DIVORCE REFORM AT THE CROSSROADS 6, 24 (Stephen D. Sugarman \& Herma Hill Kay eds., 1990) [hereinafter Kay, No-Fault] (indicating that California provides for automatic wage assignments in divorce cases); Mary Ann Glendon, Family Law Reform in the 1980s, 44 LA. L. REV. 1553, 1559 (1984) (suggesting that "the fact of having children impresses a lien upon all of the parents' income and property to the extent necessary to provide for the children's decent subsistence"). For further discussion of the collateral securing the debt in a PSA, see infra section III(A)(1) and subpart III(B). 
A state legislature promulgating PSAs could have them arise in at least two different ways: either as a matter of law, or through the parties executing a writing that describes the collateral and conveys the security interest. Both of these methods are routine in the context of commercial security arrangements; mechanic's and repair liens arise as a matter of law, ${ }^{20}$ while other security agreements require a signed writing. ${ }^{21}$ As described below, PSAs could arise either way and still play a significant role in alleviating the twin problems of displaced homemaker indigency and the general devaluation of women's work. ${ }^{22}$

PSAs could improve the results produced by, and the theoretical justifications for, current domestic relations law governing the distribution of assets upon divorce. Under current law, courts generally distribute marital property equitably when the marriage dissolves and award alimony (or maintenance, as it is currently called) only if one spouse can show need and the other is able to pay. ${ }^{23}$ Despite the law's often hyperbolic solicitude for the traditional family as the cornerstone of society, ${ }^{24}$ dissolution rules often fail to compensate primary homemakers for their work in maintaining the traditional family. ${ }^{25}$ A recent wave of scholarship has

20. See U.C.C. $\$ 9-310$ (1995) (describing liens that arise as a matter of law to secure payment for goods or services).

21. See id. § 9-203 (requiring a signed writing to create a security interest when the secured party does not possess the collateral).

22. See infra section $\mathrm{III}(\mathrm{C})(1)$.

23. Section 308 of the Uniform Marriage and Divorce Act ("UMDA") provides that a court should order maintenance "only if . . . the spouse seeking maintenance: (1) lacks sufficient property to provide for his reasonable needs; and (2) is unable to support himself through appropriate employment or is the custodian of a child whose condition or circumstances make it appropriate that the custodian not be required to seek employment outside the home." UNIF. MARRIAGE AND DIVORCE ACT $\$ 308$, at 446 (amended 1973), 9A U.L.A. 446 (1998). Section 308 further directs courts to take into account six factors in determining the amount and duration of maintenance, including:

(1) the financial resources of the party seeking maintenance . . ; (2) the time necessary to acquire sufficient education or training to enable the party seeking maintenance to find appropriate employment; (3) the standard of living established during the marriage; (4) the duration of the marriage; (5) the age and physical and emotional condition of the spouse seeking maintenance; and (6) the ability of the spouse from whom maintenance is sought to meet his needs while meeting those of the spouse seeking maintenance.

Id.

Although the UMDA uses the term "maintenance" to describe post-divorce payments from one spouse to another, this Article generally uses the term "alimony," as do most of the participants in the theoretical debate about post-divorce income sharing. While practice distinguishes sharply between alimony and property division, courts and commentators have faltered when pressed to distinguish clearly between the two. See 2 CLARK, supra note 7, § 16.1, at 179-83 (reviewing the differences between alimony and property division). Accordingly, while this Article focuses on alimony, the PSA could as easily be classified as a division of property.

24. See, e.g., Loving v. Virginia, 388 U.S. 1, 12 (1967) ("Marriage is one of the "basic civil rights of man,' fundamental to our very existence and survival." (quoting Skinner v. Oklahoma ex rel. Williamson, 316 U.S. 535, 541 (1942))).

25. See infra subpart II(A). 
addressed this problem by proposing (and critiquing) theories justifying alimony ${ }^{26}$ or reinvigorating post-divorce income sharing. ${ }^{27}$ This Article

26. See, e.g., MARTHA Albertson Fineman, The Illusion of EQUality 47, 176 (1991) [hereinafter FINEMAN, ILlUSION]; Kristian Bolin, The Marriage Contract and Efficient Rules for Spousal Support, 14 INT'L REV. L. \& ECON. 493 (1994); Margaret F. Brinig \& June Carbone, The Reliance Interest in Marriage and Divorce, 62 TUL. L. REV. 855 (1988) [hereinafter Brinig \& Carbone, Reliance]; June Carbone, Income Sharing: Redefining the Family in Terms of Community, 31 Hous. L. REV. 359 (1994) [hereinafter Carbone, Income]; June Carbone \& Margaret F. Brinig, Rethinking Marriage: Feminist Ideology, Economic Change, and Divorce Reform, 65 TUL. L. REV. 953 (1991) [hereinafter Carbone \& Brinig, Rethinking]; Lloyd Cohen, Marriage, Divorce, and Quasi-Rents; or, "I Gave Him the Best Years of My Life," 16 J. LEGAL STUD. 267 (1987) [hereinafter Cohen, Best]; Ellman, Theory, supra note 11; Ann Laquer Estin, Can Families Be Efficient?, 4 MrCH. J. GENDER \& L. 1 (1996) [hereinafter Estin, Efficient]; Ann Laquer Estin, Love and Obligation: Family Law and the Romance of Economics, 36 WM. \& MARY L. REV. 989 (1995) [hereinafter Estin, Love]; Ann Laquer Estin, Economics and the Problem of Divorce, 2 U. CHI. L. SCH. RouNDTABLE 517 (1995) [hereinafter Estin, Problem]; Ann Laquer Estin, The Case for Maintenance Reform, 23 Colo. LAw. 53 (1994); Ann Laquer Estin, Maintenance, Alimony, and the Rehabilitation of Family Care, 71 N.C. L. REV. 721 (1993) [hereinafter Estin, Maintenance]; Martha L.A. Fineman, Masking Dependency: The Political Role of Family Rhetoric, 81 VA. L. REV. 2181 (1995) [hereinafter Fineman, Masking]; Kay, No Fault, supra note 19; Herma Hill Kay, An Appraisal of California's No-Fault Divorce Law, 75 CAL. L. REV. 291 (1987) [hereinafter Kay, Appraisal]; Herma Hill Kay, Equality and Difference: A Perspective on No-Fault Divorce and Its Aftermath, 56 U. CIN. L. REV. 1 (1987) [hereinafter Kay, Equality]; Joan M. Krauskopf, Theories of Property Division/Spousal Support: Searching for Solutions to the Mystery, 23 FAM. L.Q. 253 (1989); Joan M. Krauskopf, Recompense for Financing Spouse's Education: Legal Protection for the Marital Investor in Human Capital, 28 U. KAN. L. REV. 379 (1980) [hereinafter Krauskopf, Recompense]; Elisabeth M. Landes, Economics of Alimony, 7 J. LEGAL STUD. 35 (1978); Mary E. O'Connell, Alimony After No-Fault: A Practice in Search of a Theory, 23 NEW ENG. L. REV. 437 (1988); Parkman, supra note 4, at 91; Perry, Alimony, supra note 13; Twila L. Perry, No-Fault Divorce and Liability Without Fault: Can Family Law Learn from Torts?, 52 OHIO ST. L.J. 55 (1991); H. Elizabeth Peters, Marriage and Divorce: Informational Constraints and Private Contracting, 76 AM. ECON. REv. 437 (1986); Susan Westerberg Prager, Sharing Principles and the Future of Marital Property Law, 25 UCLA L. REv. 1 (1977); Milton C. Regan, Jr., Spouses and Strangers: Divorce Obligations and Property Rhetoric, 82 GEO. L.J. 2303 (1994); Jane Rutherford, Duty in Divorce: Shared Income as a Path to Equality, 58 FoRDHAM L. REV. 539 (1990); Elizabeth S. Scott, Rational Decisionmaking About Marriage and Divorce, 76 VA. L. REV. 9 (1990); Mark A. Sessums, What Are Wives' Contributions Worth upon Divorce?: Toward Fully Incorporating Partnership into Equitable Distribution, 41 U. FLA. L. REV. 987 (1989); John C. Sheldon \& Nancy Diesel Mills, In Search of a Theory of Alimony, 45 ME. L. REV. 283 (1993); Singer, Alimony, supra note 4; Jana B. Singer, Divorce Reform and Gender Justice, 67 N.C. L. REv. 1103 (1989) [hereinafter Singer, Divorce]; Bea Ann Smith, The Partnership Theory of Marriage: A Borrowed Solution Fails, 68 TEXAS L. REV. 689 (1990); Starnes, Divorce, supra note 4; Stephen D. Sugarman, Dividing Financial Interests on Divorce, in DIVORCE REFORM AT THE CROSSROADS, supra note 19, at 130; Williams, Coverture, supra note 6; Christopher D. Nelson, Note, Toward a Compensatory Model of Alimony in Alaska, 12 ALASKA L. REV. 101 (1995).

27. Another, smaller, body of scholarship explores the issues raised by couples entering premarital agreements that allocate property and alimony rights upon dissolution. See, e.g., Kathryn Abrams, Choice, Dependence, and the Reinvigoration of the Traditional Family, 73 IND. L.J. 517 (1998); Barbara Ann Atwood, Ten Years Later: Lingering Concerns About the Uniform Premarital Agreement Act, 19 J. LEGIS. 127 (1993); Karl Fleischmann, Marriage by Contract: Defining the Terms of the Relationship, 8 FAM. L.Q. 27 (1974); Theodore F. Haas, The Rationality and Enforceability of Contractual Restrictions on Divorce, 66 N.C. L. REV. 879 (1988); Sanford N. Katz, Marriage as Partnership, 73 NOTRE DAME L. REV. 1251 (1998); Brooke Oliver, Contracting for Cohabitation: Adapting the California Statutory Marital Contract to Life Partnership Arrangements Between Lesbian, 
extends this discussion one step further by suggesting that states make PSAs part of the marriage contract.

In addition to providing a new, commercial model to justify postdivorce income sharing, PSAs have the unique potential to appeal to those with diverse ideological positions. Specifically, PSAs have much to offer legal economic, as well as liberal, cultural, and radical feminist commentators. ${ }^{28}$ Generally, law and economics scholars focus on efficiency and deterring opportunism to solve the financial problems of displaced homemakers. ${ }^{29}$ As explained below, PSAs promote efficiency and deter opportunism in marriage. Feminist scholars, in contrast, generally perceive gender inequality as the root of displaced homemaker indigency. ${ }^{30}$ Each theoretical strand of feminism, however, advances different ideas about how to achieve equality. ${ }^{31}$

Gay or Unmarried Heterosexual Couples, 23 GoLDEN GATE U. L. REV. 899 (1993); Twila L. Perry, Dissolution Planning in Family Law: A Critique of Current Analyses and a Look Toward the Future, 24 FAM. L.Q. 77 (1990); Eric Rasmusen \& Jeffrey Evans Stake, Lifting the Veil of Ignorance: Personalizing the Marriage Contract, 73 IND. L.J. 453 (1998); Marjorie Maguire Shultz, Contractual Ordering of Marriage: A New Model for State Policy, 70 CAL. L. REv. 204 (1982); Silbaugh, Marriage, supra note 12; Jana B. Singer, The Privatization of Family Law, 1992 WIS. L. REV. 1443; Jeffrey Evans Stake, Mandatory Planning for Divorce, 45 VAND. L. REV. 397 (1992); Weisbrod, supra note 4; Kaylah Campos Zelig, Putting Responsibility Back into Marriage: Making a Case for Mandatory Prenuptials, 64 U. COLO. L. REV. 1223 (1993); Leah Guggenheimer, Note, A Modest Proposal: The Feminomics of Drafting Premarital Agreements, 17 WOMEN's RTS. L. REP. 147 (1996); Allison A. Page, Note, Premarital Consent to Waiver of Spousal Pension Benefits: A Proposal to Equalize Prenuptial "I Do" and Postnuptial "I Do," 47 WASH. U. J. URB. \& CONTEMP. L. 157 (1995).

28. It may be more accurate to refer to legal economic or liberal, cultural, or radical feminist ideas rather than to particular individuals as specific kinds of economists or feminists. While the theoretical justifications of alimony roughly fall into one of these three feminist camps (or legal economic approaches), there is inevitable overlap between approaches and more complexity to each approach than an overview can take into account. The goal of this Article is not to exhaustively review income sharing proposals, which has been done ably elsewhere, see, e.g., Carbone, Income, supra note 26, but rather to cull the key elements of a broad range of theoretical approaches and suggest that PSAs have crossover potential. Balanced against the inevitable dangers of reductionism inherent in this type of synthesis-particularly when referring to key contributors as proxies for their positions-is the considerable benefit of a wide-ranging application of PSAs to the major attempts to theoretically ground postdivorce income sharing.

29. See infra subpart IV(A).

30. See infra subparts IV(B-D). See generally FINEMAN, ILluSION, supra note 26, at 36-38 (describing the financial burdens posed by the inequality in earning power and the tendency of women to assume a greater share of post-divorce childcare responsibilities); CATHARINE A. MACKINNON, FEMINISM UNMODIFIED 28-29 (1987) [hereinafter MACKINNON, FEMINISM] ("[Society] resists equal jobs for us, and equal pay when we do comparable work, yet refuses to see that our so-called options are connected: work for nothing at home, little in the workplace, and little more (at least for a while) in the street.").

31. The four ideological approaches to alimony also overlap. Cultural feminists and legal economists, for example, share a concern for protecting women in traditional gendered domestic arrangements. For a review of these schools of feminism and their approaches to marriage, see Carbone \& Brinig, Rethinking, supra note 26, at 987-1004. Carbone and Brinig's scheme differs from this Article's in that they place partnership and lost opportunity cost models in between the extremes of traditionalist legal economic approaches and liberal feminist approaches. See id. at 955-56. In 
Most liberal feminist thinkers contend that equal treatment of men and women will result in equality between the sexes. ${ }^{32}$ Cultural feminist commentators disagree, arguing that equal treatment disadvantages women because the baselines favor men. ${ }^{33}$ Recognition of women's experiences and contributions, they assert, promotes equality. ${ }^{34}$ Contemporary radical feminist scholars seek to eradicate inequality by undermining the existing dualistic constructs of male and female that subordinate women to men; thus, they advocate a complete restructuring of what society understands as available gender roles. ${ }^{35}$ While feminist approaches to gender equality

contrast, this Article places cultural feminist scholars in between legal economic and liberal scholars. This understanding reflects the cultural feminist focus of Starnes's and Singer's partnership models of post-divorce income sharing. See Singer, Alimony, supra note 4, at 2453-60 (espousing a model that treats post-divorce income as jointly owned for a period following a divorce); Starnes, Divorce, supra note 4, at 71 (recasting divorce in the dissociation vocabulary of the Revised Uniform Partnership Act).

32. See Herma Hill Kay, Equality and Difference: The Case of Pregnancy, 1 BERKELEY WOMEN's L.J. 1, 26-27 (1985) ("[W]omen in general are not different from men in innate ability."); Sylvia A. Law, Rethinking Sex and the Constitution, 132 U. PA. L. REV. 955, 969 (1984) (arguing that reproductive functions "have been used to justify sex-based legal and cultural limitations on human potential," and that "the appropriate function of the law is not to enforce a general vision of what men and women are really like, but rather to respect each person's authority to define herself or himself, free from sexdefined legal constraints"); Joan C. Williams, Deconstructing Gender, 87 MICH. L. REV. 797, 837 (1989) [hereinafter Williams, Deconstructing] ('Sameness feminists' focus on the similarities between individual men and individual women led them to advocate 'gender-neutral' categories that do not rely on gender stereotypes to differentiate between men and women.").

33. Martha Fineman has called this "result equality," in contrast with what she dubs "rule equality." Martha L. Fineman, Implementing Equality: Ideology, Contradiction and Social Change, A Study of Rhetoric and Results in the Regulation of the Consequences of Divorce, 1983 WIS. L. REV. 789, 791-92.

34. See Marie Ashe \& Naomi R. Cahn, Child Abuse: A Problem for Feminist Theory, 2 TEX. J. WOMEN \& L. 75, 103-05 (1993) (asserting that gender neutrality undermines women's unique role in society and suggesting that law should protect their special interests in order to promote equality); Robin West, Jurisprudence and Gender, 55 U. CHI. L. REV. 1, 71-72 (1988) (calling for a feminist jurisprudence based on the connecting experiences of women). Cultural feminism, as used in this Article, recognizes and seeks to increase the social and economic value of the work that many women do in caring for their families. It does not assume that women do this work because they have some universal or essential ethic of care. For further discussion, see infra section IV(C)(1).

35. Reasonable minds can differ about how to describe a radical feminist approach. Some scholars use "radical" as an epithet. See, e.g., Richard A. Posner, The Radical Feminist Critique of Sex and Reason, 25 CONN. L. REV. 515, 516 (1993) (defining radical feminism as the "rejection of biological and economic science, rejection of the evidence of one's senses, a left-wing vocabulary thick with words like 'patriarchal,' 'hegemonic,' 'colonizing,' and 'classism,' and dislike of men coupled with suspicion of heterosexuality"). Catharine MacKinnon, though often described as radical, see, e.g., Gary Minda, The Jurisprudential Movements of the 1980s, 50 OHIO ST. L.J. 599, 628-30 (1989), claims that her feminist approach is not "radical," but rather is "simply feminism." MACKINNON, FEMINISM, supra note 30, at 137. Perhaps radical feminism is not so much associated with a particular position (such as MacKinnon's dominance approach to gender relations) as it is with whatever approach is currently changing the fundamental ways in which we think about sex and gender. This Article accordingly uses the term radical feminism to describe what others might call postmodern or $1990 \mathrm{~s}$ feminism. In this sense, radical feminism's current incarnation could be described as deconstructionist. Seen in this light, the most influential radical feminist at this moment may well be philosopher Judith Butler, who has provided fruitful foundations for understanding the contingency of gender and has 
differ significantly, they all seek to reveal the contingency of gender and thus promote a new understanding of gender that facilitates equality between men and women. ${ }^{36}$ As discussed below, PSAs have the potential to further the goals of liberal, cultural, and radical feminism in several ways: they treat men and women the same; they accord economic and social value to the homemaking work done by many women; and they have the potential to seriously undermine the constructed dichotomies of male/female and market/family by combining the powerful market role of secured creditor with the economically weak, domestic role of primary homemaker. ${ }^{37}$

Because PSAs satisfy much of what feminists as well as legal economists seek to achieve, they could garner widespread support in the academic community and influence the mainstream debate about divorce reform. Perhaps most importantly, PSAs could have a significant impact on the lives of conventional families by altering society's views and valuations of the contributions of men and women to the marital enterprise.

Part II of this Article explores the twin problems of displaced homemaker indigency and the general devaluation of women's work. Part III proposes PSAs as a solution to the problems identified in Part II, and Part IV suggests that PSAs satisfy much of what law and economics

suggested ways in which unexpected contexts offer opportunities for exploiting that contingency toward feminist ends. See JUDITH BUTLER, GENDER TROUBLE (1990) [hereinafter BUTLER, GENDER]; JUDITH BUTLER, BODIES THAT MATTER 2-3 (1993) [hereinafter BUTLER, BODIES]. In the debate about the financial impact of divorce on homemakers, there are several radical feminist proposals and critiques (in the sense that they ask us fundamentally to reconsider the nature of gender, family, and marriage). See Martha Albertson Fineman, The Neutered Mother, The SeXual Family, and OTHER TWENTIETH CENTURY TRAGEDIES 158-59 (1995) [hereinafter FINEMAN, NEUTERED]; JOAN WILLIAMS, UNBENDING GENDER: MARKET WORK AND FAMILY WORK IN THE 20TH CENTURY (forthcoming 1999) (manuscript at 24 on file with the Texas Law Review) [hereinafter WILLIAMS, UNBENDING]; Williams, Coverture, supra note 6, at 2257-60; Comment, Patriarchy is Such a Drag: The Strategic Possibilities of a Postmodern Account of Gender, 108 HARV. L. REV. 1973, 2004-06 (1993) [hereinafter Comment, Patriarchy]. For discussion of the radical feminist elements of these approaches, see subpart IV(D), infra.

36. The delineation of feminist approaches as liberal, cultural, and radical is one of the more basic ways to describe various strands of feminism, but it is sufficient for the purposes of evaluating PSAs' applicability to other proposals to reinvigorate alimony. For a division of feminist legal theory into three similar categories, see Patricia A. Cain, Feminist Jurisprudence: Grounding the Theories, 4 BERKELEY WOMEN's L.J. 191, 198-204 (1989-90) (suggesting that feminist legal scholarship has progressed through three stages: formal equality; "women are different from men;" and postmodernism). While Cain categorizes MacKinnon as both radical, see id. at 204, and part of "stage two" feminism in her focus on women's difference from men by virtue of their subordination, see id. at 200-01, this Article treats postmodern feminism as synonymous with radical feminism, and it incorporates Judith Butler's theory of gender performativity into Cain's scheme. See infra subpart IV(D). For another summary of legal feminist approaches, see MARY BECKER ET AL., CASES AND MATERIALS ON FEMINIST JURISPRUDENCE: TAKING WOMEN SERIOUSLY 67-118 (1994) (excerpting six feminist approaches to gender inequality, including the dominance critique of formal equality, a defense of formal equality, hedonic feminism, pragmatism, socialist feminism, and postmodern feminism).

37. See infra Part IV. 
scholars, and liberal, cultural, and radical feminist scholars prioritize in family law. Part V considers that PSAs may not satisfy all theoretical objectives but concludes that most concerns with PSAs are either groundless or apply to any post-divorce income sharing model. In sum, Parts IV and $\mathrm{V}$ suggest that PSAs offer a concrete, if partial, solution that provides something for all concerned about the long-standing problems of devalued feminine labor and displaced homemaker impoverishment. Finally, Part VI contends that even if PSAs fall short of these ultimate goals, they still can serve as a mechanism to implement most of the other proposals for justifying post-divorce income sharing.

\section{The Problems: Displaced Homemaker Indigency and the Devaluation of Women's Work}

\section{A. Devalued Feminine Labor and Displaced Homemakers}

The twin problems of displaced homemaker indigency and devaluation of female labor are largely gender-related. ${ }^{38}$ While a single legal innovation cannot disrupt entrenched gender inequality, measures directed toward commodifying homemaking have the potential to contribute significantly to the alleviation of inequities. PSAs, which would commodify homemaking, should appeal to two often distinct groups of people: those concerned with protecting women's traditional roles, and those eager to transform these traditional roles to achieve gender equality. Divorce reform has attracted the attention of both of these groups because, at divorce, gendered financial inequalities raise persistent policy questions. ${ }^{39}$

As a result of divorce, many displaced homemakers live at or near the poverty line. ${ }^{40}$ In contrast, former husbands' standard of living increases post-divorce. ${ }^{41}$ Although all former homemakers are not impoverished,

38. See SUSAN MOLlER OKIN, JUSTICE, GENDER, AND THE FAMILY 24, 138 (1989) (observing that the division of labor within marriages generally causes women to be exploited within the marriage and the working world); FucHS, supra note 6, at 4 (stating that the weaker economic position of women is the result of conflicts women face between career and family).

39. See Fineman, Illusion, supra note 26, at 44 (describing how marriage disguises women's poverty and divorce reveals it).

40. As of 1990 , displaced homemakers' median personal income was $\$ 6766$; this figure went up to only $\$ 14,922$ for displaced homemakers with a college degree. See WOMEN WORK!, WOMEN WORK, POVERTY PERSISTS: A STATUS REPORT ON DISPLACED HOMEMAKERS \& SINGLE MOTHERS IN THE UNITED STATES 32 (1994). Displaced homemakers' income differs according to race and education. In 1990, white displaced homemakers with eight or fewer years of education made about the same as college-educated, Asian-American displaced homemakers, and the median income of African-American, Hispanic, and Native-American displaced homemakers fell between these extremes. See id. at 33.

41. Lenore Weitzman's famous data suggested that wives' standards of living decreased $73 \%$ postdivorce, while husbands' standards increased $42 \%$ after divorce. See WEITZMAN, supra note 17 , at 339. Subsequent studies have failed to validate these extreme findings, but they still have revealed a significant disparity between husbands' and wives' standards of living after divorce. See, e.g., Richard 
most (particularly women of color) still suffer more economically upon divorce than their primary wage-earning former spouses. ${ }^{42}$ Moreover, Congress's 1996 reform of welfare law, which drastically reduced the safety net that caught numerous casualties of divorce, has worsened many displaced homemakers' economic straits. ${ }^{43}$

Several social and legal factors make the homemaker's situation particularly bleak. First, she is unlikely to get any post-divorce, long-term maintenance, and she is unlikely to receive even short-term maintenance unless she can show both that she is unable to support herself, and that the primary wage earner can afford to pay after meeting his own needs. ${ }^{44}$ Even if the court awards alimony, her former spouse may not pay it. ${ }^{45}$ Moreover, remarriage represents her best shot at economic stability, yet age diminishes marriage prospects for older women, and children act as barriers to younger women's remarriage. ${ }^{46}$ Additionally, the limited

R. Peterson, A Re-evaluation of the Economic Consequences of Divorce, 61 AM. SOC. REv. 528, 53033 (1996) (replicating Weitzman's research on the same data set and finding a 27\% decrease in women's post-divorce standard of living and a $10 \%$ improvement for men); Lenore J. Weitzman, The Economic Consequences of Divorce Are Still Unequal: Comment on Peterson, 61 AM. Soc. REV. 537, 537-38 (1996) (explaining that the original data is no longer available, but conceding sample weighting error); Saul D. Hoffman \& Greg J. Duncan, What Are the Economic Consequences of Divorce?, 25 DEMOGRAPHY 641,641 (1988) (reporting that the economic status of women declines about $30 \%$ in the first year after divorce); Herbert Jacob, Faulting No-Fault, 1986 AM. B. FOUND. RES. J. 773, 77475 (1986) (criticizing Weitzman's methodology).

42. The Displaced Homemaker Network has reported that $57 \%$ of all displaced homemakers live in or near poverty; women of color disproportionately suffer from such impoverishment. See Starnes, Divorce, supra note 4, at 79-80 \& n.51 (describing a 1990 status report published by the Displaced Homemakers Network that indicated that $61 \%$ of African-American and $62.3 \%$ of Hispanic displaced homemakers are poor, compared to $27.8 \%$ of white displaced homemakers).

43. See JULIE A. NiCe \& LOUISE TRUBECK, CASES AND MATERIALS ON POVERTY LAW: THEORY AND PRACTICE 618-20 (1997); DEBORAH L. RHODE, SPEAKING OF SEX: THE DENIAL OF GENDER INEQUALITY 197, 201 (1997); Dorothy E. Roberts, Spiritual and Menial Housework, 9 YALE J.L. \& FEMINISM 51, 80 (1997). Welfare reforms increasing child support enforcement might benefit some displaced homemakers. See NICE \& TRUBECK, supra, at 688-89. However, such collection efforts may yield modest results because the fathers of many poor women's children are also poor, and states have encountered difficulty in implementing the enforcement mechanisms. See id.; see also Virginia Ellis, Calif. Drops Deadbeat Tracking System, DENV. POST, Nov. 23, 1997, at 10A (describing California's abandonment of its $\$ 100$ million computer system for tracking deadbeat parents).

44. See UNIF. MARRIAGE AND DIVORCE ACT § 308, at 446 (amended 1973), 9A U.L.A. 446 (1998).

45. See WerrzMAN, supra note 17 , at 169 (reporting that within six months of divorce, one of every six men owed unpaid alimony); Deborah L. Rhode \& Martha Minow, Reforming the Questions, Questioning the Reforms: Feminist Perspectives on Divorce Law, in DIVORCE REFORM AT THE CROSSROADS, supra note 19, at 191, 202 (noting that only around one-half of all spousal maintenance awards are fully paid); Sugarman, supra note 26, at 130, 134 (stating that many men default on their spousal maintenance obligations).

46. See FUCHS, supra note 6 , at 19-22 (describing the declining marriage prospects for women at mid-life due to sex ratios and social patterns of men marrying younger women); Greg J. Duncan \& Saul D. Hoffman, A Reconsideration of the Economic Consequences of Marital Dissolution, 22 DEMOGRAPHY 485,485 (1985) (reporting that approximately $55 \%$ of white women and $42 \%$ of 
employment opportunities available to an older displaced homemaker who has been out of the workforce for an extended period, if not for her entire life, are exacerbated by age and sex discrimination. Furthermore, she is likely to have custody of any children born during the marriage, and though child support was awarded, the wage earner likely does not pay in full. ${ }^{47}$ As a result, the displaced homemaker and her children are likely to be economically distressed.

Historically, the gendered nature of marriage resulted in the legal invisibility of the wife under the doctrine of coverture, which dictated that a woman's property became her husband's. ${ }^{48}$ Despite contemporary formal equality rhetoric in reforms intended to abolish coverture, many marriages retain remnants of the traditional gender roles, which legal rules also perpetuate. ${ }^{49}$ Thus, marriage remains defined in large part by gender and sex duality. As long as women's domestic work remains devalued under this rubric, that duality operates to the detriment of homemakers and all women. ${ }^{50}$

The continued centrality of gender in marriage was starkly revealed in the recent wave of anti-gay marriage statutes. ${ }^{51}$ The legislative history

African-American women remarry within 5 years of divorce); Landes, supra note 26, at 51 (discussing a woman's age and number of children as impacting the value of her "marriage skills").

47. See CENSUS, StaTISTICAL ABSTRACT, supra note 6, at 389 (describing data that in 1991 only $52 \%$ of parents awarded child support received full payment, $24 \%$ received partial payments, and fully 25\% received no payments at all); Marsha Garrison, The Economics of Divorce: Changing Rules, Changing Results, in DIVORCE REFORM AT THE CROSSROADS, supra note 19, at 75, 87 (discussing a study indicating that "wives obtained physical custody in more than four out of five cases").

48. See Siegel, Home, supra note 5, at 1082 (indicating how the common law gave a husband "responsibility to represent and support his wife, giving him in return the use of her real property and absolute rights in her personalty and 'services'-all products of her labor"). Interspousal tort immunity and other remnants of coverture lasted until the late twentieth century. See 1 CLARK, supra note 7, $\hat{8} 11.1$, at 632 .

49. See Siegel, Protection, supra note 5, at 1119 (noting how status law, through doctrines regulating marriage, is preserved despite attempts to reform it); Williams, Coverture, supra note 6, at 2229-30 (discussing the need for property laws, unchanged since coverture, to be altered in a manner that no longer allocates all of the ideal worker's post-divorce income to him).

50. In the nineteenth century, American feminists attempted to reform the common-law rules devaluing women's work by arguing that female domestic labor contributed to family wealth, entitling wives to $50 \%$ of maritai property. See Siegel, Home, supra note 5, at 1076. Instead of recognizing these joint property claims, legislatures granted part (perhaps the less important part) of the nineteenth century feminists' demands by enacting earnings statutes that enabled wives to keep the proceeds of their wage labor. See id. at 1077 . However, even the earnings statutes, which benefited relatively few women, were narrowly interpreted to apply only when the woman segregated her earnings from other family income and the husband was not earning any income at all. See id. at 1184-87. The more modern, Marxist-feminist claims of wages for housework similarly aim to elevate women's status generally by remunerating their domestic work. As such, they serve feminist purposes "in revaluing the contribution women have always made, in demonstrating the essentiality and value of women's most degraded and most universal functions." MACKINNON, FEMINIST THEORY, supra note 8, at 65.

51. At least 36 states considered bans on same-sex marriage; Congress and at least 16 states enacted legislation refusing to recognize same-sex marriage. See Harriet Chiang \& David Tuller, Judge OKs Same-Sex Marriages, S.F. CHRON., Dec. 4, 1996, at A1. 
of the federal anti-gay marriage measure, titled the Defense of Marriage Act ("DOMA"), ${ }^{52}$ aptly illustrates both the extreme reverence mainstream American culture holds for traditional marriage ${ }^{53}$ and that such reverence largely centers on the gendered nature of the institution. ${ }^{54}$ DOMA defends "traditional heterosexual marriage" 55 as an intrinsically gendered institution composed of a man and a woman in appropriate roles dictated by biological roles in reproduction. These roles, not surprisingly, are the primary breadwinner and primary caretaker. ${ }^{56}$

52. 28 U.S.C. $\S 1738(C)$ (Supp. 1998) (precluding federal recognition of same-sex marriage and permitting states to refuse to recognize them).

53. See H.R. REP. No. 104-664, at 12-15 (1996), reprinted in 1996 U.S.C.C.A.N. 2905, 291619; see also Lloyd R. Cohen, Rhetoric, the Unnatural Family, and Women's Work, 81 VA. L. REV. 2275, 2290 (1995) [hereinafter Cohen, Rhetoric] (calling marriage a way "to harness men's energies to support the only offspring they may legitimately have" and denouncing "equalitarian partnership" theories as "pernicious"); F. Carolyn Graglia, The Housewife as Pariah, 18 HARV. J.L. \& PUB. POL'Y 509,509 (1995) (criticizing feminists for attacking women's traditional roles as wives and mothers).

54. See H.R. REP. NO. 104-664, at 12, reprinted in 1996 U.S.C.C.A.N. at 2916 (emphasizing that "the basis of the idea of the family . . . consist[s] and spring[s] from the union for life of one man and one woman in the holy state of matrimony" (quoting Murphy v. Ramsey, 114 U.S. 15, 45 (1885) (emphasis omitted)); Andrew Koppelman, Why Discrimination Against Lesbians and Gay Men Is Sex Discrimination, 69 N.Y.U. L. REv. 197, 202 (1994) (suggesting that the ban on same-sex marriage "preserves the polarities of gender on which rests the subordination of women").

55. The testimony focused on one major issue: defending "traditional heterosexual marriage." H.R. REP. No. 104-664, at 12, reprinted in 1996 U.S.C.C.A.N. at 2916 ("Congress . . can . . . defend the institution of traditional heterosexual marriage" (enıphasis added)); see also Defense of Marriage Act, May 15, 1996: Hearings on H.R. 3396 Before the Subcomm. on the Constitution of the House Comm. on the Judiciary, 104th Cong. 32 (1996) [hereinafter Hearings] (statement of Rep. F. James Sensenbrenner, Jr.) ("I will plead guilty to my bias for maintaining and strengthening traditional heterosexual marriage." (emphasis added)); id. H.R. REP. No. 104-664, at 33, reprinted in 1996 U.S.C.C.A.N. at 2916 ("[F]our legitimate government interests are advanced by this legislation: (1) defending . . . the institution of traditional, heterosexual marriage; (2) defending traditional notions of morality; (3) protecting state sovereignty and democratic self-governance; and (4) preserving scarce government resources." (emphasis added)). The testimony is predictably vague about what precisely "traditional heterosexual marriage" is, and how same-sex marriage threatens it. See, e.g., Hearings, supra, at 61 (statement of Marilyn Musgrave, Rep., Colo. State House of Representatives) ("[]f we redefine marriage . . . I can't even imagine all the ramifications that that would have. . . . What about the education of our children? What about health education? What about Madison Avenue? What about advertising? The cultural changes will go on and on if we choose to redefine marriage.").

56. See Hearings, supra note 55, at 41 (prepared statement of the National Gay and Lesbian Taskforce) ("The view of the extreme Radical Right is that the only 'right family' is that which fits its definition. ... [T]his 'perfect traditional family' . . . is a family composed of a working man and a woman staying at home with their children."); see also H.R. REP. NO. 104-664, at 13 n.48 (1996), reprinted in 1996 U.S.C.C.A.N. at 2916 ("Marriage' is not an arbitrary construct; it is an 'honorable estate' based on the different, complementary nature of men and women-and how they refine, support, encourage, and complete one another." (quoting William J. Bennett, . . But Not a Very Good Idea, Either, WASH. POST, May 21, 1996, at A19)). Congress further clarified that the gendered nature of marriage allows it to serve its primary purpose: begetting and raising children. See H.R. REP. No. 104-664, at 14 n.50 (1996), reprinted in 1996 U.S.C.C.A.N. at 2916 ("Marriage is the central cultural resource for reconciling men and women's separate natures and different reproductive strategies. Indeed, the most important purpose of marriage is to unite men and women in a formal partnership that will last through the prolonged period of dependency of a human child." (quoting Barbara Dafoe 
The gendered nature of marriage is linked to the financial plight of displaced homemakers. ${ }^{57}$ Commodifying domestic work, which is performed primarily by women, could have at least two effects. First, it could protect many women's economic interests at divorce by remunerating them for their contributions to family wealth. Second, it could contribute to equalizing marital roles, assuming that inequality in marriage is at least partly due to the devaluation of women's traditional contributions to the marriage..$^{58}$

\section{B. Limitations of Current Alimony Doctrine and Fault-Based Divorce}

Before describing PSAs, it is useful to briefly discuss how alimony under both no-fault and fault-based divorce cannot adequately compensate primary homemakers for their contributions to family wealth. Current divorce rules focus on property division and provide for alimony only in limited circumstances and for a brief period. ${ }^{59}$ Traditional alimony rules, consistent with a regime in which divorce was available only when one spouse was at fault, awarded alimony as a kind of damages for the other spouse's misconduct. ${ }^{60}$ Some commentators blame no-fault divorce for the economic difficulties experienced by displaced homemakers, arguing that unilateral exit options, coupled with limited alimony rights, leave

Whitehead, The War Between the Sexes, AM. ENTERPRISE, May/June 1996, at 26)); Hearings, supra nute 55, at 99-100 (prepared statement of Prof. Hadley Arkes, Amherst College) ("[S]exuality [is] imprinted in our very natures-in the obdurate fact that we are all, as the saying goes, 'engendered.' ... Our engendered existence, as men and women, offers the most unmistakable, natural signs of the meaning and purpose of sexuality. And that is the function and purpose of begetting.").

57. See FuCHS, supra note 6 , at 4 (arguing that even unmarried women make less than men because of social assumptions about married women that set female pay scales); OKIN, supra note 38, at 24 (" $[\mathrm{G}]$ ender-structured marriage is an institution that makes women economically and socially vulnerable.").

58. See June Carbone, Economics, Feminism, and the Reinvention of Alimony: A Reply to Ira Ellman, 43 VAND. L. REV. 1463, 1463 (1990) [hereinafter Carbone, Reply] ("Divorce reform and gender roles are inextricably linked."); Joan M. Krauskopf \& Sharon Burgess Seiling, A Pilot Study on Marital Power as an Influence in Division of Pension Benefits at Divorce of Long Term Marriages, 1996 J. DISP. RESOL. 169, 173 [hereinafter Krauskopf \& Seiling, Pilot] (spouses with more education, income, and professional status have more tangible power in marriages); Comment, Patriarchy, supra note 35 , at 2000 ("[D]ivorce reform has the potential to change the way that heterosexual props of marriage, family, and procreation structure women's roles.").

59. See UNIF. MARRIAGE AND DIVORCE ACT § 308, at 446 (amended 1973), 9A U.L.A. 446 (1998) (noting that alimony should be awarded "[o]nly if the available property is insufficient for the purpose [of providing for the financial needs of the spouse] and if the spouse who seeks maintenance is unable to secure employment appropriate to his skills . . or is occupied with childcare. . . "); 2 CLARK, supra note $7, \S 17.1$, at 223.

60. See 2 CLARK, supra note $7, \S 17.5$, at $221,222,267$ (stating that under the traditional conceptualization of alimony, a wife's marital misconduct either destroys or diminishes her chances of receiving an alimony award, while a husband's marital misconduct not only enhances his wife's chances but also increases the potential size of the award). 
homemakers vastly disadvantaged. ${ }^{61}$ Others recognize that homemakers also suffered under fault-based divorce regimes because women did not get the financial support necessary to maintain the standards of living they enjoyed during the marriage. ${ }^{62}$ Courts rarely awarded alimony, ${ }^{63}$ and even when they did, the awards were subject to termination based on the wife's sexual practices or other perceived misbehavior. ${ }^{64}$ Alimony was not available to wives found to be at fault, and a double standard regarding sexual misconduct granted men considerably more leeway than women. ${ }^{65}$ Alimony awards, moreover, often went unpaid, ${ }^{66}$ and even if the exhusband did pay, he still was in a better financial position than the ex-wife. Finally, an award could be reduced or terminated if either spouse

61. See POSNER, ECONOMIC, supra note 16, at 146-48 (discussing the consequences of divorce on homemakers, given their nonpecuniary contributions to their marriages); RICHARD A. POSNER, SEX AND REASON 159 n.27 (1992) [hereinafter POSNER, SEX] (arguing that no-fault divorce can lead to the systematic impoverishment of divorced women); WEITZMAN, supra note 17, at 190-94 (arguing that the self-sufficiency norms of no-fault divorce systems produce unbalanced consequences that favor men); Cohen, Best, supra note 26, at 277 (noting that a growing number of commentators argue that the combination of no-fault divorce and equitable property distributions creates inequities that work to the disadvantage of women); Landes, supra note 26, at 48 (arguing that "an efficient alimony system would penalize the party more at fault in contributing to a divorce"); Scott, supra note 26, at 13 (contending that fault-based divorce law served a beneficial purpose by imposing costs upon divorce); Barbara Bennett Woodhouse, Sex, Lies, and Dissipation: The Discourse of Fault in a No-Fault Era, 82 GEO. L.J. 2525, 2552 (1994) (arguing that no-fault divorce serves to remove the protections attached to the homemaker's historically dependent status without providing an alternative means to gain financial independence). Although all states recognize irreconcilable differences as a ground for divorce, some states retain fault grounds, as well. However, fault is still considered in a number of jurisdictions as relevant to property distribution, alimony, or both. Sce Ira Mark Ellman, The Place of Fault in a Modern Divorce Law, 28 ARIZ. ST. L.J. 773, 778-84 (1996) [hereinafter Ellman, Place] (reviewing divorce regimes in states that consider fault in varying degrees to determine post-divorce distribution of property and alimony); Kristine Cordier Karzenis, Annotation, Fault as Consideration in Alimony, Spousal Support, or Property Division Awards Pursuant to No-Fault Divorce, 86 A.L.R.3d 1116 (Supp. 1998).

The no-fault movement was initially driven by widespread objections to the way that the fault system encouraged perjury and interfered with spouses making a clean break from the marriage. See Kay, Appraisal, supra note 26, at 299; Kay, Equality, supra note 26, at 62. Nevertheless, as the idea of no-fault divorce spread, many feminists supported its implicit rejection of traditional gender roles. See Kay, Equality, supra note 26, at 56.

62. See Kay, Equality, supra note 26, at 67; Singer, Divorce, supra note 26, at 1106-12; Sugarman, supra note 26 , at 133 . For a comprehensive account of how California law governed divorce before and after the enactment of no-fault divorce, see Kay, Appraisal, supra note 26, at 293297. For a systematic analysis of how alimony rules themselves (rather than doctrinal changes regarding fault as grounds for divorce) explain women's increasingly disadvantaged position post-divorce, see Garrison, The Economics of Divorce, supra note 47, at 92.

63. See Singer, Divorce, supra note 26, at 1106-07; Sugarman, supra note 26, at 135.

64. See Singer, Divorce, supra note 26, at 1109-10. For further discussion of how reinstating fault-based divorce will not benefit women or children, see Katharine T. Bartlett, Saving the Family from the Reformers, 31 U.C. DAVIS L. REV. 809, 834-43 (1998).

65. See Singer, Divorce, supra note 26, at 1110-11. Richard Posner has defended this double standard as economically efficient. See POSNER, ECONOMIC, supra note 16, at 161-62; POSNER, SEX, supra note 61 , at 252.

66. See O'Connell, supra note 26 , at 437 \& n.2. 
remarried. ${ }^{67}$ Thus, fault-based divorce, as administered, was an ineffective tool to protect displaced homemakers or to commodify homemaking labor. ${ }^{68}$ Legal economic scholars and liberal, cultural, and radical feminist scholars all have suggested divorce reforms to commodify homemaking, but no single proposal has secured support across ideological boundaries. The legal economic camp focuses on efficiency and deterring opportunism and therefore adopts a contractual view of marriage. ${ }^{69}$ Some legal-

67. See Singer, Divorce, supra note 26 , at 1108 .

68. Reinstating fault-based divorce has other drawbacks besides being ineffective to combat displaced homemaker indigency or the general devaluation of women's work. First, it would resurrect the perjury and fraud that no-fault divorce was designed to prevent. See Lawrence M. Friedman, Rights of Passage: Divorce Law in Historical Perspective, 63 OR. L. REv. 649, 659 (1984) (noting the prevalence of collusion in turn-of-the century divorce cases as some states required proof of adultery before they would grant a divorce); Lawrence M. Friedman \& Robert V. Percival, Who Sues for Divorce? From Fault Through Fiction to Freedom, 5 J. LEGAL STUD. 61, 62-68 (1976) (discussing the deceptive tactics spouses employed to obtain a divorce under a fault-based system). Second, reinstating fault-based divorce would implicitly sanction traditional gender roles, which serve as the basis for alimony under fault-based divorce. Alimony has been linked to nineteenth-century notions of sin and the necessity for husbands to support wives due to increased female economic dependence in the age of domesticity, see O'Connell, supra note 26, at 467,469, and to the husband's common-law duty to support his wife, see 2 CLARK, supra note 7, § 17.1, at 220-21. Thus, while fault-based divorce might give resisting spouses increased bargaining power to negotiate better separation contracts, see Ellman, Theory, supra note 11, at 6 ("The modern reforms that left the law of divorce with no rationale for alimony also altered the negotiating environment for divorcing spouses so that the divorced wife today has much less leverage than she once had."); Robert H. Mnookin \& Lewis Komhauser, Bargaining in the Shadow of the Law: The Case of Divorce, 88 YALE L.J. 950, 969 (1979) (suggesting that a legal rule recognizing alimony would benefit both spouses), it would also hinder the liberal feminist goal of encouraging female economic independence and the general feminist goal of allowing women an exit from abusive or otherwise unhappy marriages. See Sara McLanahan \& Lynne Casper, Growing Diversity and Inequality in the American Family, in 2 STATE OF THE UNION: AMERICA IN THE 1990s 1, 34, 35 (Reynolds Farley ed., 1995) (describing a contemporary ideology of marriage that prefers personal freedom and economic independence of women over marital commitment). Finally, a return to fault-based divorce conflicts with the current social construction of marriage as a vehicle for self-fulfillment, which largely has replaced earlier constructions of marriage as service to church or family. For a review of various historical constructions of marriage, see MARY ANN GLENDON, THE TRANSFORMATION OF FAMILY LAW: STATE, LAW, AND FAMILY IN THE UNITED STATES AND WESTERN EUROPE 5 (1989). Some conservatives disagree with the current understanding of marriage as focused on individual self-fulfillment and concentrate instead on the religious or community aspects of marriage. Louisiana, for example, recently created covenant marriage, under which fiancées may opt into a fault-based system for marriage dissolution. See Kevin Sack, Louisiana Approves Measure to Tighten Marriage Bonds, N.Y. TIMES, June 24, 1997, at A1. Some commentators wonder whether fiancées will fully understand the impact of opting back into the fault-based divorce rules. See, e.g., Margaret Carlson, Till Depositions Do Us Part, TiME, July 7, 1997, at 21, 21. Even if fault remains relevant for some limited purposes (such as justifying a generous alimony or property award to an especially aggrieved spouse), such an understanding would neither commodify homemaker contributions to family wealth nor increase the value accorded female labor because the contributions of homemakers usually are unrelated to whether they or their wage-earning spouses are at fault. See infra note 335 and accompanying text.

69. See, e.g., Cohen, Best, supra note 26, at 267-68. Some feminist commentators similarly propose a partnership model of marriage and divorce to justify alimony. See, e.g., Singer, Alimony, supra note 4, at 2454-56 (arguing for an equitable division that would recognize the contribution, 
economic scholars are traditionalist in their view of gender roles, while others are feminist. ${ }^{70}$ Feminist legal economists contest traditionalist arguments about the efficiency of gendered labor specialization; instead they suggest that contractual reliance or restitution interests justify postdivorce income-sharing. ${ }^{71}$ Some reject strict contractarian approaches to marriage, for example preferring a "covenant" model of marriage that accounts for its status elements. ${ }^{72}$ Thus, economic methodology and feminist concerns are not mutually exclusive.

Liberal, cultural, and radical feminist scholars have proposed approaches to post-divorce income sharing that both differ from, and converge with, those adopted by legal economists. Liberal feminist proponents are unlikely to support strong measures that reinvigorate alimony. They contend that alimony disserves women because it discourages them from becoming ongoing participants in the wage labor force, and that it reinforces traditional gender roles. ${ }^{73}$ Cultural feminist approaches vary considerably, but all focus on valuing the homemaking contributions of women to the marital enterprise.

Radical feminist approaches to divorce reform differ from liberal and cultural approaches in their effort to move away from the dualistic view of gender. Radical feminist analysis, rather than asking for women to be treated the same as men (liberal feminism) or in accordance with unique female needs and experiences (cultural feminism), seeks to undermine the hierarchy of men over women by subverting the binaries that construct gender hierarchy (such as male or female and market or family). ${ }^{74}$ Despite the obvious and considerable ideological differences among these

regardless of form, that both spouses make); Starnes, Divorce, supra note 4, at 119-30 (applying buyout and dissociation principles to divorce law).

70. Compare BECKER, supra note 16 , at $62-63$ (defending gendered specialization of labor as efficient), with Margaret F. Brinig, Comment on Jana Singer's Alimony and Efficiency, 82 GEO. L.J. 2461, 2469-73 (1994) [hereinafter Brinig, Comment] (contesting the efficiency of labor specialization).

71. Brinig and Carbone have published widely in this area, taking nuanced approaches to justifying alimony that bridge significant elements of the contract-status paradox in marriage. For works illustrative of their contractual approach, see Brinig \& Carbone, Reliance, supra note 26, at 856-57 (defining and defending a reliance interest in marriage, with qualifications); Carbone \& Brinig, Rethinking, supra note 26 , at $1000 \mathrm{n} .202$ (identifying restitution as the emerging model for justifying post-divorce income sharing); see also Brinig, Comment, supra note 70, at 2469-73 (challenging the efficiency of gendered labor specialization). Carbone similarly focuses on community aspects of family, such as the "larger social obligation to provide for childrearing." Carbone, Income, supra note 26, at 362.

72. Brinig, Comment, supra note 70, at 2461-65.

73. See Kay, Equality, supra note 26, at 80, 89-90; Kay, Appraisal, supra note 26, at 309. Kay also has expressed support for post-divorce income sharing when one spouse has incurred a loss due to some marital sharing behaviors. See Kay, No-Fault, supra note 19, at 33-34.

74. See BUTLER, GENDER, supra note 35. Deborah Rhode and Martha Minow have similarly suggested that effective divorce reform (effective in the sense of fostering substantive gender equality) must bridge the public and private spheres. See Rhode \& Minow, Reforming the Questions, in DIVORCE REFORM AT THE CROSSROADS, supra note 19, at 191, 194. 
approaches, PSAs have the unique potential to achieve crossover acceptance. Prior to discussing the versatility of PSAs, however, it is necessary to explain their nature and scope.

\section{The Proposed Solution: Commercializing Marriage Through Premarital Security Agreements}

Commercializing marriage through PSAs provides a logical resolution to the debate over how to value women's domestic work. Legislation recognizing PSAs could occur in two ways: either as a matter of law (like a mechanic's lien), or when a couple executes a PSA as a prerequisite to obtaining a marriage license. In either case the security agreement would secure repayment of the primary wage earner's debt to the homemaker by designating fifty percent of marital property (including post-divorce income) as collateral for the loan. ${ }^{75}$ In a commercial context, default often is defined as failure to repay a loan. ${ }^{76}$ Under the PSA, however, default is defined as termination of a marriage. ${ }^{77} \mathrm{~A}$ more comprehensive understanding of PSAs requires a brief review of how ordinary commercial security agreements operate.

75. When post-divorce wages are the most important marital asset, the homemaker would "repossess" them through garnishment proceedings. This could be as simple as filing an affidavit with a state agency or court that would administer the garnishment proceedings. The affidavit would determine the amount of the unpaid debt based on the difference between the spouses' income at the time of divorce, the length of the marriage, and the number of years until the youngest child turns 18 . The homemaker's representations in her affidavit would be governed by commercial standards of good faith and fair dealing. Good faith is defined under the U.C.C. as "honesty in fact in the conduct or transaction concerned." U.C.C. § 1-201(19) (1995). Some commercial actors are governed by an elevated standard of good faith. Merchants, for example, are bound to a higher standard of good faith that requires "observance of reasonable commercial standards of fair dealing in the trade" in addition to honesty in fact. Id. § 2-103(1)(b). The recent revisions to Article 9 adopt this heightened standard of good faith, further supporting the use of this standard in the PSA context. See U.C.C. § 9102(a)(43) (amended 1998) (defining "good faith" as "honesty in fact and the observance of reasonable commercial standards of fair dealing"). This heightened good faith standard could apply to homemakers as well, binding them to reasonable standards of fair dealing in divorce as they exercise their self-help remedies.

76. Commercial parties can and often do define additional occurrences as events of default. See WHITE \& SUMMERS, supra note $9, \S 25-2$, at 902.

77. In order to protect homemakers from being "starved out"-pressured to accept unfair property division or alimony agreements-notice of divorce could constitute default under premarital security agreements. See Penelope Eileen Bryan, The Coercion of Women in Divorce Settlement Negotiations, 74 DENV. U. L. REV. 931, 931 (1997) (explaining that women often are forced to accept poor divorce settlements in order to meet their immediate needs and those of their dependent children); see also Sugarman, supra note 26, at 161 (advocating a model of redistribution in which the marital assets and income are split for a period of time commencing with the notice of the filing for divorce). Statutes that allow courts to allocate attorneys' fees in divorce based on spouses' incomes alleviate the danger of a bad deal for the spouse whose more modest income hinders her from retaining counsel or maximizing attomey involvement in the case. However, these fee-shifting statutes arguably create a companion danger-that a full-time homemaking spouse might opportunistically threaten protracted litigation at the other's expense, forcing the primary wage earner to agree to her settlement terms. See, e.g., Colo. REV. STAT. \& 14-10-119 (1998) (authorizing a court to shift attorney's fees). 


\section{A. Applying Commercial Security Agreements to Marriage}

Article 9 of the Uniform Commercial Code governs secured transactions between creditors and debtors when personal property secures the debt. ${ }^{78}$ Uniform, predictable rules encourage commercial creditors to extend credit to debtors by making it relatively easy for creditors to secure loans through security interests in collateral. ${ }^{79}$ Using the memorable phrase of Article 9 drafter, Grant Gilmore, Article 9 is intended to make creating a security interest as easy as "rolling off a log," so that even widows and orphans could create a valid security interest. ${ }^{80}$

One of the most important rights a secured creditor enjoys is the right, upon default, to repossess property that the debtor has identified as collateral for the loan. After repossession, a secured creditor can either keep the collateral or sell it. ${ }^{81}$ This self-help remedy is made possible by the earlier creation of a security interest; self-help rights significantly benefit creditors by relieving them of the expensive, burdensome, and timeconsuming process of judicially foreclosing on a defaulted loan. In short, Article 9 gives secured creditors the brass ring of self-help rights in order to encourage those creditors to extend credit. ${ }^{82}$

78. See U.C.C. § 9-102 (defining the applicability of Article 9). Article 9 governs secured transactions whether the collateral is tangible or intangible personal property. See id. $\S 9-105$ and $\mathrm{cmt}$. 3 (discussing types of property subject to a security agreement); id. § 9-106 (defining general intangibles); id. § 9-109 (classifying types of goods). Article 9 is appropriate to use as a template for PSAs because it has been adopted in every state (with occasional nonuniform amendments) and is straightforward in its rules and their applications. Doctrinally, Article 9 would require alteration to govern PSAs because it does not apply to security agreements where the collateral is "wages, salary, or other compensation of an employee," id. § 9-104(d), or interests in real property, see id. § 9-104(j). Thus, to the extent that PSAs create security interests in real property, they can be governed by real estate finance law, see id. § 9-501(4), but recognizing PSAs' security interest in post-divorce income would require legislative action. Article 9 drafters excluded transactions in which future wages served as collateral in deference to state statutes that narrowly limit the circumstances in which an employee can assign her or his wages. See id. $\S 9-104 \mathrm{cmt}$. 4. A legislative amendment recognizing security interests in post-divorce income, however, would be relatively simple, since wage garnishment is already an accepted method of collecting child support and maintenance payments. See, e.g., CoLo. REV. STAT. § 14-14-111.5 (establishing a system of "income assignment" to collect family law debts).

79. See Grant Gilmore, Security Law, Formalism and Article 9, 47 NEB. L. REV. 659, 668 (1968) (noting that simpler security laws make it easier for all people to take personal property security interests). The Article 9 drafters reasoned that facilitating credit is economically justified by its salutary effects on commerce generally. See Homer Kripke, Law and Economics: Measuring the Economic Efficiency of Commercial Law in a Vacuum of Fact, 133 U. PA. L. REV. 929, 946-48 (1985).

80. See Gilmore, supra note 79, at 668 . While Gilmore's example of widows and orphans was apparently meant to contrast Article 9 with the labyrinthine methods of creating and perfecting security interests under pre-Article 9 law, his example of widows and orphans as parties generally thought to be commercially unsophisticated (and perhaps financially vulnerable) is particularly apt in this context. See id.

81. See U.C.C. §§ 9-504, 9-505; WHITE \& SUMMERS, supra note 9, § 25-4, at 907 (“[The creditor] can seize the goods subject to the security interest and either keep them in satisfaction of the debt or apply the proceeds to the debt.").

82. A simple example illustrates a typical Article 9 transaction. Assume that GMAC financed the purchase of a Jeep for Diane Debtor through an Article 9 security agreement in which Diane granted 
Under Article 9, a creditor generally secures repayment of a loan by executing a security agreement with the debtor. ${ }^{83}$ A security agreement must satisfy three requirements: (1) the debtor must sign a writing that grants the creditor a security interest and describes the collateral; (2) the creditor must give value in exchange for the security interest; and (3) the debtor must have an interest in the collateral. ${ }^{84}$ PSAs would satisfy all three of these requirements.

1. Obtaining a Signed Writing.-To be enforceable, a commercial security agreement must take the form of a writing signed by the debtor that describes the collateral with reasonable certainty. ${ }^{85}$ Both spouses would sign the PSA so that the primary homemaker would be protected regardless of which spouse devoted primary attention to domestic responsibilities. ${ }^{86}$ This execution process would be simple because fiancées could sign the security agreement along with other documents they

GMAC a security interest in the Jeep to secure the loan. Diane missed several payments and still owed $\$ 20,000$ on the Jeep. Because Diane has defaulted. GMAC can repossess the Jeep without any judicial procedure, and either resell it or keep it. If GMAC sells the Jeep and only gets $\$ 15,000$, then GMAC can sue Diane for the deficiency $(\$ 5,000)$. See U.C.C. $\$ \$ 9-503,9-504$ (establishing a right to take possession upon default, sell the collateral, and collect any deficiency from the debtor). Had GMAC not secured the loan with a security interest in the Jeep, it would have had to sue Diane for the whole $\$ 20,000$. But since GMAC followed the Article 9 requirements to create its security interests, it can repossess the Jeep and recover nearly all of its lost money, plus the costs of repossession and resale. Clearly, Article 9 is a big improvement for creditors over pursuing judicial process to recover on failed loans. Under PSAs, a homemaker would step into the shoes of GMAC in this transaction. She would be a creditor in relation to her wage-earning spouse, and, upon default, would have the right to repossess the collateral, including garnishing a percentage of his post-divorce wages.

83. U.C.C. § 9-203(1). A creditor can also create a security interest by possessing the collateral. Id. While possessing collateral has some potential relevance for PSAs, this Article focuses on the security interest created by a written security agreement because in most cases any marital property possessed by a primary homemaker is also possessed by her spouse.

84. Id.

85. Id. The description must "reasonably identif[y] what is described." Id. § 9-110. Generally speaking, descriptions are sufficient if they classify collateral using Article 9 terms such as "all debtor's accounts receivable" or "all debtor's inventory, now owned, or hereafter acquired." WHITE \& SUMmERS, supra note 9, § 22-3, at 759-61. The Official Comment to § 9-110 clarifies that the Code does not require the security agreement or financing statement to list collateral by serial number or other painstaking specificity. U.C.C. $\S 9-110 \mathrm{cmt}$.

86. As discussed in section IV(B)(2), infra, PSAs are intentionally sex-neutral; they could apply to either male or female homemakers. This sex (but not gender) neutrality makes them cohere with various strands of feminist thought. See Williams, Deconstructing, supra note 32, at 839 . Colorado already requires both spouses to sign a security agreement if the collateral is consumer goods owned by a married person. CoLO. REV. STAT. § 4-9-203(2) (1998). This rule does not apply to the purchase money security interests or collateral covered by a federal statute or treaty, or a state certificate of title statute. Since Colorado recognizes common-law marriage, secured creditors wanting to comply with this provision likely err on the side of having any cohabiting couple sign security agreements which designate consumer goods as collateral. See People v. Lucero, 747 P.2d 660, 665 (Colo. 1987) (providing that maintaining joint bank and credit accounts evidences a common-law marriage). 
complete when they apply for a marriage license. Thus, obtaining a signed writing that grants a security interest would not burden the fiancées or the state. In addition to the signature requirement, the writing must describe the collateral. Given the long-term nature of the marriage relation and the limited information fiancées have regarding the assets they will accumulate during the marriage, describing collateral in a PSA may be more complicated than it is in many commercial secured transactions.

In typical security agreements, collateral must be described with sufficient detail to identify the things described. ${ }^{87}$ PSAs could describe the collateral as follows:

Fifty percent of all marital property acquired during the marriage (regardless of which spouse contributes funds or holds title thereto), including but not limited to: real and personal property; the primary wage earner's post-divorce stream of income; general intangibles (including, but not limited to, business goodwill); accounts receivable; instruments; consumer goods; inventory; farm products; and equipment. ${ }^{88}$

Most of the property listed above already is subject to distribution at divorce. ${ }^{89}$ PSAs, however, would improve divorce law in two important ways: (1) by creating a security interest in one-half of all marital property

87. See U.C.C. § 9-110. In Colorado, a security interest in consumer goods must both "identify and itemize ... what is described" in order for a security agreement to attach. COLO. REV. STAT. § 4-9-110. The security agreement in the text might not satisfy this heightened standard for consumer goods, since it describes but does not identify particular consumer goods (for example, by specifying one queen-size Beauty Rest mattress). However, the consumer goods are not the most valuable assets in most divorces and are worth almost nothing on resale. See FEDERAL TRADE COMM'N, CREDIT PRACTICES: FTC STAFF REPORT AND RECOMMENDATIONS ON PROPOSED TRADE REGULATION RULE 192-242 (1980) (excerpted in RAYMOND T. NIMMER \& INGRID MICHELSEN HILLINGER, COMMERCIAL TRANSACTIONS: SECURED FINANCING 33-35 (1992)). While it might benefit a homemaker/secured creditor to take possession of household furnishings upon divorce, retain them, and forfeit her right to collect a deficiency from her primary wage-earning husband/debtor pursuant to U.C.C. § 9-505(2), these rights are modest in comparison to obtaining rights in the primary wage earner's stream of income or other business assets such as goodwill and accounts. See Brinig, Property, supra note 7, at 95-96.

88. This description should exclude separate property, such as inherited property or property received as a separate gift, from the definition of marital property. See 2 CLARK, supra note 7, § 16.2, at 183-84. The agreement could be tailored to particular kinds of marital property by having the parties check boxes identifying the particular types of property they anticipate acquiring during the marriage and specify exceptions for separate property such as gifts or inheritances received by individual spouses. This method might be problematic, however, given that many spouses do not know what kinds of property they will acquire during their marriages. Moreover, some commentators suggest that divorce is more likely to occur when one or both spouses' expectations differ from their actual experiences. Thus, as one spouse becomes more rich or famous than she had expected, she might divorce in order to marry a spouse better suited to her upgraded lifestyle. See BECKER, supra note 16, at 335 (noting that married couples often reassess their marriages after they have learned more about each other's behavior and capability).

89. See 2 CLARK, supra note $7, \S 16.2$, at 184. 
at the outset of the marriage; and (2) by counting fifty percent of the primary wage earner's post-divorce income (and other business assets) as collateral securing the marital debt. These two changes may seem extreme, but a comparison to commercial secured transactions indicates that PSAs merely extend to primary homemakers the same protections commercial secured creditors routinely require as a condition for extending credit. ${ }^{90}$

2. Giving Value by the Creditor.-The second requirement for an Article 9 security interest is that the creditor gives value in exchange for the security interest in the collateral. ${ }^{91}$ Under the PSA model, the primary homemaker/creditor must give the primary wage earner/debtor value. Under Article 9, value is an elastic term, ${ }^{22}$ but it usually takes the form of a lender extending credit to a debtor.

a. What does the homemaker give in value?-A homemaker gives value by performing domestic services that enable the primary wage earner to become an ideal worker and prevent the homemaker from maximizing her own earning potential. These services benefit the marriage and family, and the primary homemaker expects that her efforts and sacrifice will be part of a lifetime joint endeavor. ${ }^{93}$ Numerous legal economists suggest that women generally make these marriage-specific investments in the early years of the marriage and that men make their marriage-specific investments later in the marriage. ${ }^{94}$ Like a commercial creditor, a primary homemaker extends value expecting that it will be returned to her with interest to compensate her for taking the risk and for foregoing other uses

90. See infra section $\mathrm{III}(\mathrm{C})(2)$.

91. See supra text accompanying note 84 .

92. See U.C.C. § 1-201(44) (defining value to include any consideration sufficient to support a simple contract); WHITE \& SUMMERS, supra note 9, § 22-39(d), at 762 (describing the value requirement as nearly a dead letter).

93. See Landes, supra note 26 , at 45 ("The wife is willing to invest in her husband's earning capacity at cost to herself only because ... she has a claim to future eamings generated by her investment."). Landes also notes:

[M]arried men have both higher earnings and longer, healthier lives than their unmarried counterparts. By spending more time in household production, a wife directly frees some of her husband's time to the market, increasing both his current market earnings and his incentive to invest in earnings-augmenting skills. Id. at 40.

94. See BECKER, supra note 16 , at 30-31, 42 (explaining that women engage in childrearing early in marriage while husbands make investments in their own human capital in the market sector); Cohen, Best, supra note 26, at 287 ("As a rule, men tend to obtain gains early in the relationship when their own contributions to the marriage are relatively low and that of their wives relatively great. Similarly, later on in the marriage women tend as a general rule to obtain more from the contract than do men."); see also POSNER, ECONOMIC, supra note 16, at 164 (indicating that one function of alimony may be to repay wives for their early investments in the household). 
of her assets. ${ }^{95}$ Joan Williams describes this situation as the "dominant domestic ecology." 96 The husband typically is the primary wage earner, and the wife takes care of the home and the children, often in addition to part-time or secondary wage labor. ${ }^{97}$ In addition to extending credit to her primary wage-earning spouse for these domestic services, the primary homemaker forfeits other opportunities she would enjoy if she became an ideal worker. ${ }^{98}$

Thus, the typical marriage involves the primary homemaker's provision of household services in exchange for a share of the primary wage earner's wages. This exchange entitles her to compensation for these services, but precisely valuing these is either impossible because there is no market equivalent for them or inadequate because the market value of those services which are available for sale is depressed by the general devaluation of domestic work and those who perform it. ${ }^{99}$ Therefore,

95. See POSNER, ECONOMIC, supra note 16 , at 163 . Posner queries whether the primary homemaker is more analogous to a lender or an equity-type investor and whether the debt might have been repaid over the course of a long marriage. See id. at n.1.

96. Williams, Coverture, supra note 6, at 2229. Unlike many legal economists, Williams rejects the focus on homemakers' lost opportunity costs as inadequate to capture the losses women suffer as a result of successful gender training (i.e., not ever building career assets to sacrifice due to anticipated focus on domestic responsibilities) and also inadequate in that it allocates to the primary wage earner all of the benefits and only some of the costs of gendered labor specialization. See id. at 2254-57 (arguing that these benefits and costs continue after divorce because the primary homemaker typically retains custody of the children, thereby limiting her market opportunities and allowing the primary wage eamer continued income maximization).

97. Twila Perry has described this model as the "paradigm marriage" and criticized it as excluding the marriages of many women of color and low-income women. See Perry, Alimony, supra note 13, at 2486, 2486-95. She suggests that many poor women and women of color do not share white feminists' eagerness to escape the cult of domesticity because they were never indoctrinated into it. See id. at 2494, 2488-94 ("For women who do not have the option of attractive well-paying professional jobs, staying home may not be considered a sacrifice. "). Most disadvantaged women must work, and they do not have the so-called choice that middle- and upper-middle class women have to cut back on their participation in the wage labor force to care for their own homes and children. See id. at 2488-89. Moreover, low-income women and women of color are less likely than higher-status women to marry men with access to sufficiently high wages to qualify them for ideal-worker status, and some women of color view mothering as resistance to oppression rather than subordination to men in that it involves preparing their children "to survive in a racially hostile world." Id. at 2491, 2489-91. Comparing the income of men and women of color with that of white men and women supports Perry's contention that white couples are more likely to fit Williams's model of the dominant domestic ecology than marriages of people of color (assuming that most marriages are intraracial). See CENSUS, INCOME, supra note 6 , at $26-27$ tbl.7.

98. See Cohen, Best, supra note 26 , at 285 (noting that women generally end up worse off after divorce because women's improved homemaking skills have little market value compared to men's career investments); Ellman, Theory, supra note 11, at $46-47$ (explaining that this choice is economically rational when the husband's work is more economically rewarding than the wife's work); Parkman, supra note 4, at 102-03 (concluding that the "loss experienced by the divorced spouse . . . is often underestimated because the impact of decisions during marriage on her income earning capacity ... is usually ignored in the financial arrangements at divorce" $)$.

99. See Estin, Efficient, supra note 26, at 21-23. Nineteenth-century feminists also recognized this devaluation of female labor in the home. See Siegel, Home, supra note 5, at 1094 ("[T] he antebellum 
merely providing restitution or reliance damages based on a comparison with either what the homemaker could have earned as an ideal worker, or the market value of her homemaking services, systematically undervalues domestic work.

b. How much does the homemaker give in value?-It is one thing to claim that a divorced homemaker has an entitlement to a percentage of her former spouse's post-divorce income. It is quite another to specify the exact extent of her interest. If the percentage is too high, it might diminish the wage earner's motivation to participate productively in the work force. If the percentage is too low, it would inadequately provide for the displaced homemaker.

There is no consensus on the value of homemaking services. Experts in wrongful death, personal injury, or divorce litigation cases commodify homemaking contributions through at least three different calculations: replacement cost, lost opportunity cost, and econometric models. The simplicity of replacement cost makes it the most popular among lawyers, but this measure is malleable given the uncertainty of whether the replacement for meal preparation is the employment of a gourmet chef or a short-order cook, and how to account for multitasking. ${ }^{100}$ Opportunity cost measures look at a homemaker's market options, but this method often devalues homemaking if there is no market equivalent to the services provided in the home. ${ }^{101}$ Econometric models might value a homemaker's contributions by calculating the efficiencies of cohabitation based on how much money a single parent would have to spend to obtain the services of a family homemaker. ${ }^{102}$ Assume, for example, that a household of two parents and two children has an income of $\$ 100,000$. If one of the parents, with both children, would need an income of $\$ 140,000$ to obtain the same services provided within the two-parent family, then the value of household production would be $\$ 40,000 .^{103}$ The complexity of econometric models for valuing homemaking prevents them from being popular with lawyers and judges, but these models are widely used in academic research. Lawyers and judges prefer the imperfect, but relatively simple, replacement

women's rights movement did insist upon the economic value of wives' household labor, and challenged the doctrine of marital service as it expropriated the value of that work."); see also Roberts, supra note 43, at 52 (describing how the depressed value of menial housework delegated to poor women, often racial minorities, is related to the distinction drawn between that work and spiritual homemaking performed by higher-status women who delegate the menial housework).

100. See Fischer, supra note 10, at 193-96.

101. See id. at 188. While defense attorneys in personal injury or wrongful death cases prefer opportunity cost models to value a homemaker's work because they tend to yield a lower valuation than replacement cost, these attorneys often rebut a plaintiff's replacement-cost valuation rather than risk conceding liability by having their own expert. See id. at 190 .

102. See id. at 191.

103. See id. 
cost calculations. ${ }^{104}$ A fourth measure for evaluating the worth of homemaking looks to whether having a primary homemaking spouse enhances a wage earner's income. Two recent studies suggest that men with homemaking wives earn around twenty percent more than men whose wives work full-time outside the home. ${ }^{105}$ This range of methods to value a homemaker's contribution, and the malleability of each method, indicates that any mode used to calculate the amount of debt a primary wage earner owes to the primary homemaker is subject to criticism. Perhaps the best justification of any particular calculation is that it improves on the current valuation of homemaker contributions, which are worthless.

This Article proposes the following formula as a method to calculate the contributions of primary homemaking to family wealth:

$$
\text { (.3(high income - low income)) } \frac{\text { Annual Payment }}{\text { (length of marriage }}+\left(\frac{\text { Duration }}{2}+(18-\text { age of youngest minor child)) }\right.
$$

This formula defines the debt as annual payments in the amount of thirty percent of the difference between the spouses' incomes at the time of the divorce. The total debt is, of course, determined by the duration of these payments-duration is half the length of the marriage plus the time until the youngest child reaches majority.

Each element of the formula reflects part of what the primary homemaker contributes to family wealth. Calculating the difference between the spouses' incomes accounts for the fact that primary homemakers earn less money in wage labor because of their focus on childcare and other homemaking responsibilities. ${ }^{106}$ The thirty percent reflects both the ways in which homemaking services contribute directly to primary wage earner income, ${ }^{107}$ and the lost opportunity costs born by those who devote primary attention to homemaking. ${ }^{108}$ The durational element of the

104. See id. at 192.

105. See Joy A. Schneer \& Freida Reitman, Effects of Alternative Family Structures on Managerial Career Paths, 36 ACAD. MGMT. J. 830, 831, 836 (1993) (finding that male MBA degree holders with homemaker spouses and children made $20 \%$ more than men whose spouses worked for wages, controlling for age, hours, experience, employment gap, and field of responsibility); Linda K. Stroh \& Jeanne M. Brett, The Dual-Earner Dad Penalty in Salary Progression, 35 HUM. RESOURCE MGMT. 181, 195 (1996) (finding that the incomes of male managers whose spouses were homemakers increased $11 \%$ more than those whose spouses worked full-time); Tamar Lewin, Men Whose Wives Work Earn Less, Studies Show, N.Y. Times, Oct. 12, 1994, at Al (noting that several studies have found that men whose wives work earn less than men whose wives do not work outside the home).

106. See FUCHS, supra note 6, at 41.

107. See Schneer \& Reitman, supra note 105 , at 833 (observing that wives contribute to their husbands' success by assuming the roles of work assistant, consultant, social director, and counselor); Stroh \& Brett, supra note 105, at 191 (describing homemakers as career resources who allow the primary wage earners to have higher salary levels than dual-earner families).

108. See Ellman, Theory, supra note 11, at 17 (suggesting that a stay-at-home wife forgoes specific training or employment opportunities to accommodate her husband's career). Perhaps $20 \%$ of the 
formula reflects both the homemaker's predivorce contribution to the ideal worker's post-divorce income (by having the payments last for a period equal to half of the marriage, thus accounting for increased homemaker contributions over time) and post-divorce homemaker contributions (by continuing to serve as the child's primary caretaker, thus freeing the primary wage earner to maintain his ideal worker status). ${ }^{109}$ The lengthof-marriage (length of marriage divided by 2 ) provision in the duration calculation protects the interest of older primary homemakers (whose children are nearly or likely grown). The age-of-youngest-child element of the duration calculation (18 minus age of youngest child) accounts for the contributions of younger homemakers with children, whose contributions to the ideal worker's status will continue for some time after the divorce. If the typical divorce involves a four-year marriage and two children, then the premarital security interest would attach to a percentage of the primary wage earner's income until two years after the youngest child turns eighteen. ${ }^{110}$ For young primary homemakers with no children, the debt is appropriately small in recognition of their more modest contributions to family wealth. Applying this formula to several hypothetical divorces yields annual payments ranging from $\$ 2860$ to $\$ 11,887$, and total debts ranging from $\$ 8580$ to $\$ 166,418$. $^{111}$

income differential is attributable to the direct ways that having a homemaking spouse facilitates ideal worker status, see Stroh \& Brett, supra note 105, at 197, while the other $10 \%$ might reflect the primary homemaker's lost opportunity costs. The American Law Institute has recognized the difficulties in determining the percentage of income differential that should be divided upon divorce, leaving it up to states to adopt a particular percentage. See AMERICAN LAW INSTITUTE, 1 PRINCIPLES OF THE LAW OF FAMILY DISSOLUTION: ANALYSIS AND RECOMMENDATIONS §§ 5.05-.06 (Proposed Final Draft 1997) [hereinafter ALI, PRINCIPLES]. This income-sharing proposal has received support. See Bartlett, supra note 64 , at 847 .

109. Singer suggested the formula of one year of post-divorce income sharing for every two years of marriage. See Singer, Divorce, supra note 26, at 1117 . Williams then expanded it, taking into account young women with children by proposing income sharing until the youngest child reaches majority and adding Singer's half-of-the-marriage-duration term to the end of this period. See Williams, Coverture, supra note 6, at 2260-61. This model also furthers the important concerns of young mothers.

110. See Williams, Coverture, supra note 6, at 2261. Williams sets out another example describing a 54 year-old homemaker divorced after 30 years when her youngest child leaves home. In that situation, this model mandates income sharing for 15 years, until the homemaker turns 69 . This time period protects an older woman from being dumped into the wage labor force with skills decades out of date, and it gives her time to either retrain or save. See id. at 2260-61. As an alternative, the payments could be indefinite for long marriages in which the primary homemaker is over a certain age at the time of divorce, given the unlikelihood that a primary homemaker in her sixties could start from scratch to fully support herself. See J. Thomas Oldham, ALI Principles of Family Dissolution: Some Comments, 1997 U. ILL. L. REV. 801, 826. This additional time that the homemaker is credited for, after the children reach majority, serves two purposes: it allows the homemaker to improve her market skills by going back to school or engaging in full-time training once she no longer has responsibility for the children, and it accounts for many children's continued financial dependence on their parents even after reaching the age of majority.

111. See infra notes $116-19$ and accompanying text. 
These calculations are solely financial and credit only primary homemakers' domestic labor. While emotional and other nonfinancial considerations motivate people to enter (and terminate) the marriage contract, and also to inform their conduct during marriage, ${ }^{112}$ these factors play no role in solving the problem of displaced homemaker indigency. At divorce, aspirational values of love and obligation usually are displaced by each spouse's monetary concerns.

The PSA model may seem to present an overly simplified picture of marriage in which one spouse does all the domestic work and the other does none of it. Certainly, some couples share domestic work, and even in the most traditional marriages, primary wage earners participate in some homemaking activities. In some marriages, one spouse is both the primary wage earner and the primary homemaker. However, recent research indicates that the simple picture of primary homemaker and primary wage earner is more common than one might suspect.

A 1987 study found that women reported doing an average of 38.1 hours of household labor per week, compared to 21.9 hours per week for men. ${ }^{113}$ Moreover, men and women's household tasks affect their labor force participation differently. Typical male tasks might include getting oil changed in the family car or mowing the lawn, while typical female tasks might include laundry, picking up children, and meal preparation. Because the man's household tasks can be done on a more flexible time schedule or on weekends, no one within the family is seriously burdened if the task is put off for a short period. Thus, male household tasks are less likely to interfere with participation in the paid labor force. Women's domestic work, in contrast, is often more time consuming and must be done on a strict schedule; consequently, it is more likely to interfere with wage labor. ${ }^{114}$ Hence, premarital security interests reflect the value extended by the primary homemaker that adds to the income producing potential of the primary wage earner, despite the fact that in most marriages both spouses do some household and wage labor. PSAs reflect the fact that primary homemakers do most of the domestic work, and that this work interferes with their immediate and future market participation-factors that provide both a justification and a mechanism for valuing and remunerating homemaking labor. ${ }^{115}$

112. See Estin, Love, supra note 26 , at 1021-22 ("Economic theory fails to recognize both love, which does not assume self-interest, and obligation, which exists despite self-interest. It also ignores the wide range of less admirable motivations in family behavior such as spite, rage, and guilt.").

113. See SHELTON, supra note 6 , at 65 . This number is more remarkable when viewed in light of Shelton's methodological choice to exclude childcare from her definition of housework. See id. at 7; see also HOCHSCHILD, supra note 6, at 3,8 (finding that when full-time employment, housework, and childcare are added, women work approximately 15 hours longer each week than men).

114. See HoCHSCHILD, supra note 6 , at 8 .

115. See FuCHS, supra note 6, at 72-74. 
Three hypothetical divorces illustrate how the formula proposed here would apply.

Case 1: High school graduates, both working full-time, year-round, have no children, and divorce after six years of marriage.

Male income: $\$ 30,709$

Female income: $\$ 21,175^{116}$

$30 \%$ of the $\$ 9534$ difference between their incomes: $\$ 2860$ (annual payment)

Paid for 3 years, making total debt $\$ 8580$

This calculation demonstrates that the annual payment and total debt will be both relatively modest for most couples who both work full-time. Given that primary homemakers' responsibility for most housework and childcare diminishes their wages in the market, it does not seem unreasonable to designate the value of that domestic work (and attendant lost opportunity costs) at $\$ 2860$ a year.

Case 2: Same facts as Case 1, except that the couple has a three year-old child.

Durational changes: 18 years instead of 3 years

Annual payment is the same (\$2860)

Total debt is $\$ 51,480$

His total income over these 18 years is $\$ 552,762$

This calculation reflects the primary homemaker's post-divorce contributions to the primary wage earner's income. Women's wage labor force participation has skyrocketed since 1960, but their economic well-being has stayed the same largely because of lower wages for women and their continued responsibility for most household labor. ${ }^{117}$ Calculating the amount of debt owed to a primary homemaker as thirty percent of the difference between spouses' incomes takes this pattern into account while acknowledging that the primary wage earner puts considerable individual effort into his

116. Income figures are based on data provided by the Census Bureau. See CENSUS, INCOME, supra note 6 , at 29 tbl.7.

117. See FUCHS, supra note 6, at 3-4. The major exception to the general nonimprovement of women's economic status is young, well-educated, unmarried white women, whose economic wellbeing improved substantially between 1960 and 1986. While some of these women are divorced or widowed, the majority of them do not have children, and their economic well-being may not continue after marriage, when they are more likely to struggle between devoting resources to career and family. See id. 
work. As such, the calculation both compensates primary homemakers for their services (and attendant sacrifices) while maintaining incentives for continued productivity on the part of primary wage earners. The child will not be in school for two years, and even after that will need considerable care and attention that will impinge on the primary homemaker's market labor. The annual payments of $\$ 2860$ reimburse her for these services (and lost opportunity costs) while the child is a dependent, and then it gives her some time to build up her own human capital through education or training once the child leaves home. Most couples would not have the resources to pay off the $\$ 51,480$ debt in a lump sum, thus, making the annual payments relevant in most circumstances. However, if PSAs became widespread, the insurance industry might market divorce insurance to allow divorcing couples to pay off the debt at the time of divorce rather than over time. ${ }^{118}$

Case 3: Both spouses are college graduates, and the wife is a full-time homemaker. They have three children and divorce after twenty years, when the youngest child is fourteen. She has not worked in the wage labor force for eighteen years.

Difference in their incomes: $\$ 39,624^{119}$

$30 \%$ of difference: $\$ 11,887$ (annual payment)

Duration is 14 years

Total debt is $\$ 166,420$ (30\% of his total income of $\$ 554,736$ )

This calculation accounts for the debt incurred during a long marriage when the children have already left home, or will leave home before the debt would be repaid, using just the age of the children to determine the duration of annual payments. The relatively high annual payment recognizes that the primary homemaker did the majority of homemaking since she was not engaged in any wage labor. Even so, this payment is not much more than minimum wage for her full-time attention to homemaking labor. ${ }^{120}$ Because she has been out of the workforce for nearly two decades, her market skills are extremely out of date, making her

118. Divorce insurance could implicate public policy concerns, such as conflicting with the state interest in preserving marriage and raising the risk that couples might fraudulently obtain a divorce to collect on the policy.

119. See CENSUS, INCOME, supra note 6, at 26 tbl.7 (using the average income figure of a male with a bachelor's degree (not necessarily engaged in full-time, year-round employment)).

120. Minimum wage is $\$ 5.15$ an hour. See 29 U.S.C. § 206(a) (Supp. II 1996). Full-time, yearround minimum wage employment yields $\$ 10,300$ annually. See BETTY SOUTHARD MURPHY \& ELLIOT S. AZOFF, BUREAU OF NAT'L AFFAIRS, GUIDE TO WAGE AND HOUR REGULATION 29 (2d ed. 1998) [hereinafter MURPHY \& AZOFF, WAGE GUIDE]. 
opportunity costs for being a full-time homemaker particularly high. Moreover, her investments in family wealth came on the front end of the marriage, as she assumed primary caretaking responsibilities for their three children. Her re-entry into the wage labor force is further hindered by age discrimination.

These payments would be separate from child support, because they represent a return on the marital debt rather than a sharing of responsibilities for the expenses of bringing up children. A state adopting the PSA model of implementing post-divorce income sharing could, of course, cap the payments a primary wage earner makes to his former spouse in order to safeguard a percentage of income. This formula would be a presumptive method of calculating marital debt owed to the primary homemaker; couples could produce evidence that their incomes at the time of divorce were not representative of their contributions to family wealth (if, for example, one spouse just finished a graduate program and would shortly enjoy a large increase in pay, partly due to the contributions and sacrifices of his or her spouse). However, the payments would not terminate upon either party's remarriage, because that remarriage would not diminish the primary homemaker's contributions to the primary wage earner's income system.

Of course there may be cases in which one spouse is both the primary wage earner and the primary caretaker-one is "super-spouse" and the other is literally "good-for-nothing." These facts would rebut the presumptive entitlement of the lower-income spouse to thirty percent of the difference between the spouses' salaries, but the burden of proof would be on the wage earner to establish these facts. Given the well-documented gender bias in divorce proceedings and spouses' tendencies to distort each other's homemaking participation at the time of divorce, ${ }^{121}$ the wage earner should have to carry a heavy burden (such as clear and convincing evidence).

The amount of the debt is determined based on the formula discussed above. If for some reason the primary wage earner could not meet his payments, he would have the same options that commercial debtors have in those circumstances. He could negotiate a work-out agreement in which the creditor (i.e., homemaker) could seek additional protections (such as additional collateral) to protect her interests. If it became impossible for him to pay the debt, then she would have to discharge the obligation, just as a commercial creditor dealing with an insolvent debtor would have to do. Of course, states could also apply family law rules regarding modification of the payment amount for changed circumstances. Such a practice,

121. See Williams, UNBENDING, supra note 35 (manuscript at 27) (suggesting that a father is evaluated based on "the minimal contribution expected of breadwinners, whereas a mother's contribution is judged by the gold standard of the full-time homemaker"). 
however, would conflict with the PSAs central premise that the homemaker's contributions to family wealth create an entitlement to a share of that wealth. It would, moreover, compromise the certainty and clarity offered by the calculations provided above. Given that most divorces are resolved by agreement rather than trial, ${ }^{122}$ and that many are done pro $\mathrm{se}^{123}$ the simple formula proposed here is more workable than an openended, fact-intensive inquiry.

3. Ascertaining the Debtor's Interest in the Collateral.-Having demonstrated that the PSA would involve a signed writing describing the collateral and that the homemaker/creditor extends value to the wage earner/debtor, only one requirement remains: The debtor must have an interest in the collateral. The interest need not rise to the level of complete and absolute ownership, but mere naked possession of the collateral is generally insufficient for a security interest to arise. ${ }^{124}$ PSAs can satisfy this prerequisite to create a valid security interest. Assuming that the key marital asset is the debtor/wage earner's stream of income, then he has sufficient ownership interest in his income stream under the "he who earns it, owns it" rule. ${ }^{125}$ The wage earner would similarly have sufficient ownership interest in his business goodwill, accounts receivable, equipment, inventory, or other property acquired during the marriage.

In summary, all three requirements for creating a consensual security agreement are met: the PSA involves a signed writing describing the collateral; the creditor/homemaker gives value; and the debtor/wage earner nas sufficient interest in the collateral. Thus, when the economic gains and losses of a marriage must be divided at divorce, commercial law offers a seasible model for making this financial distribution. PSAs would allow the primary homemaker to enjoy the rights and remedies of a secured creditor upon divorce.

\section{B. Addressing Possible Objections}

Several potential objections to this description exist, but none are fatal. Commercial law accommodates arrangements in which both collateral and

122. See IRA MARK Ellman ET AL., Family LaW 688 (2d ed. 1991).

123. See Robert B. Yegge, Divorce Litigants Without Lawyers, 28 FAM. L.Q. 407, 408-10 (1994) (describing an Arizona study that indicates pro se representation doubled from 1980-1985, growing from $24 \%$ to $47 \%$, and that pro se litigants "are more likely to reach an agreement on the issues before starting the case"); see also Robert H. Mnookin et al., Private Ordering Revisited: What Custodial Arrangements Are Parents Negotiating?, in DIVORCE REFORM AT THE CROSSROADS, supra note 19, at 37,60 (describing a study in which both divorcing parents were represented by counsel in $47 \%$ of the cases, and at least one parent was represented by counsel in $80 \%$ of the cases).

124. See WHITE \& SUMMERS, supra note 9, § 22-3(e), at 762-63; see also Litwiller Mach. \& Mfg., Inc. v. NBD Alpena Bank, Inc., 457 N.W.2d 163, 167 (Mich. App. 1990) (holding that a manufacturer had sufficient interests in components it had the right to assemble for sale).

125. See Williams, Coverture, supra note 6, at 2250-51. 
the debt itself fluctuate, multiple bodies of law intersect, and the collateral is worth more than the underlying debt. Moreover, PSAs need not inhibit spouses' use of property, nor an orderly disposition of property at divorce.

First, there is nothing unusual in the PSAs' inclusion of collateral that the debtor (i.e., primary wage earner) has not yet acquired. Moreover, PSAs can provide that the collateral will secure the amounts the creditor/homemaker "lends" to the debtor/primary wage earner periodically during the marriage. Commercial security agreements often take these two circumstances into account by conveying a security interest in afteracquired property, ${ }^{126}$ and providing that a security interest in particular collateral protects the lender's interest in repayment of money advanced after the initial extension of credit. ${ }^{127}$ Thus, PSAs could, consistent with secured transactions law, apply to the debtor/wage earner's currentlyowned and after-acquired collateral, and this collateral would secure the creditor/primary homemaker's continual advances of credit made during the marriage.

One potential problem with describing the collateral as done above is that the list of collateral invokes various bodies of law. When the collateral securing credit is personal property, Article 9 governs, but wages and real property are excluded from Article 9 coverage because they are covered by other statutes. ${ }^{128}$ Moreover, real estate collateral is governed by other applicable law. ${ }^{129}$ However, commercial security agreements frequently encompass collateral covered by multiple bodies of law. If commercial security agreements work despite this complication, there is no reason why PSAs would be hampered by a collateral description that invokes multiple bodies of law. Thus, a state legislating premarital security interests could either apply the Article 9 rules to PSAs-to the

126. See U.C.C. § 9-204 (1995).

127. See id. § 9-204(3). These latter contractual provisions are known as future advances clauses. See NIMMER \& HILLINGER, supra note 87, at 203-04. When a creditor extends additional credit to a debtor under a future advances clause, the amount of the debt increases and the entire debt is secured by the collateral described in the security agreement. See id. Thus, the amount of the debt varies as the creditor loans additional money to the debtor. Similarly, in PSAs, the homemaker/creditor continually extends credit to her primary wage-eamer spouse, increasing the amount of the debt secured by the PSA over the duration of the marriage. See Bank of Kansas v. Nelson Music Co., 949 F.2d 321, 323 (10th Cir. 1991) (enforcing a future advances clause).

128. U.C.C. \& 9-104 cmt. 4. Colorado's wage gamishment statute, for example, requires that the assignment be in writing for a fixed part of the garnishee's wages, apply only to wages eamed in the 30 days after assignment, be recorded in the county in which the wages are to be earned, and be joined by the spouse of the garnishee. See COLO. REv. STAT. $\$ \S 8-9-101,-103,-104$. However, courts are willing to allow rights to payment to be used as collateral even though they seem to be wages. See, e.g., First Nat'l Bank v. Rankin (In re Rankin), 102 B.R. 439, 443 (Bankr. W.D. Pa. 1989) (holding that an insurance agent's stream-of-income under an annuity was earned by virtue of his status as an independent contractor and thus was not "wages" excluded from Article 9 coverage).

129. See U.C.C. § 9-104(j); WHITE \& SUMMERS, supra note 9, § 21-6, at 739. 
extent that collateral is personal property within Article 9's scope ${ }^{130}$-or amend the relevant statutes to allow for the creation and enforcement of PSAs under one body of law.

Statutory amendment to allow for wage garnishment for family law purposes would be relatively simple. While state statutes tightly restrict debtors' right to assign wages to protect workers from getting deep in debt, ${ }^{131}$ the law does allow some assignment of wages, often for child support and maintenance payments. ${ }^{132}$ PSAs would merely give homemaking spouses self-help remedies so they could garnish their former spouses' income without an expensive and burdensome judicial procedure. Moreover, some primary wage earners' stream of income may be Article 9 collateral, such as accounts receivable, contract rights, or general intangibles. ${ }^{133}$

Stream of income and real property are often the only assets for a couple to divide when they divorce, and stream of income is generally the more important asset. ${ }^{134}$ Thus, it is important that PSAs apply to situations in which income is at least part of the collateral. However, as discussed above, strong policy reasons have induced state legislatures to make it difficult for a commercial creditor to obtain a security interest in the debtor's stream of income. ${ }^{135}$ The current default rule that homemaker contributions are worth nothing at divorce, coupled with the often dire straits of displaced homemakers (and the people for whom they care), offer compelling policy rationales for legislatures to add PSAs to the list of circumstances in which the law allows creditors to garnish wages.

A third potential objection to the collateral described in the proposed PSA is that the collateral is worth more than the debt. Under a PSA, the primary homemaker takes a security interest in fifty percent of marital property to protect her extension of credit to the marital enterprise, should the marriage end in divorce. However, as described above, the amount of this debt is only thirty percent of the difference between the spouses' incomes, a figure significantly less than fifty percent of the marital property. Thus, the collateral is worth far more than the amount of the debt. At first glance this imbalance seems inequitable. However, overcollateralizing a loan is a necessary precaution because all too often there is

130. Mixed-collateral transactions can be governed by multiple sources of law. If a security interest is secured by both personal and real property, for example, the secured party has the option of either foreclosing under Article 9, regarding the personal property, or proceeding under law governing real property for all of the collateral. See U.C.C. § 9-501(4).

131. See, e.g., Colo. REV. STAT. § 8-9-101.

132. See, e.g., id. § 14-14-111.5.

133. Contract rights are general intangibles, and thus subject to Article 9 when they are used as collateral. See U.C.C. $\$ 9-106 \mathrm{cmt}$.

134. See Brinig, Property, supra note 7, at 95-96.

135. See supra text accompanying note 131 . 
much less money available at foreclosure time than either party anticipated. ${ }^{136}$ Commercial lenders routinely oversecure loans to protect themselves if collateral depreciates, or is lost or destroyed. There is no reason to think that the collateral securing the marital security interest would be any more stable than typical commercial collateral, and perhaps there exists good reason to suspect it might be considerably less stable. This presumption of collateral depreciation justifies the over collateralization of the premarital security interest for the same reason that commercial lenders are allowed to oversecure their loans. Setting aside fifty percent of all marital property for the security interest protects the primary homemaker's interests and leaves sufficient marital property unencumbered so that commercial creditors can take security interests in it, should the spouses want to obtain credit.

Another potential concern with designating fifty percent of marital property as collateral securing the marital debt is that it might encumber marital assets and thus prevent a couple from freely using and enjoying them during the marriage. Fortunately, commercial secured transactions law addresses this problem. Under Article 9, a transferee of collateral takes free of the security interest if the secured creditor consents to the transfer. ${ }^{137}$ Applying these rules to the PSA context, the PSA would not compromise spouses' ability to use and transfer their property as they deem appropriate because the homemaker/creditor's consent could cleanse an item of collateral of the premarital security interest. This rule protects homemakers in two ways. First, primary wage earners could not destroy the security interest by transferring marital property without the primary homemaker's consent, because the security interest travels with the collateral. Purchasers of marital property would thus routinely require explicit consent of both spouses to ensure that the property was unencumbered. If the circumstances indicated homemaker/creditor consent to transfer the collateral, her consent could be inferred. ${ }^{138}$ Second,

136. See NIMMER \& HILLINGER, supra note 87 , at 7-11.

- 137. See U.C.C. $\S 9-306(2)$ (providing that a security interest "continues in collateral notwithstanding sale, exchange or other disposition thereof unless the disposition was authorized by the secured party in the security agreement or otherwise" (emphasis added)). Another exception to the general rule that the security interest travels with collateral is that buyers in the ordinary course of business take goods free of a security interest. See id. § 9-307(1). This exception is unlikely to affect the disposition of marital assets because it applies to collateral, which is routinely transferred in the course of a business, such as inventory sold by a retailer. See id. §1-201(9) (defining "buyer in the ordinary course of business"). Transfers of marital property are more likely to be one-time deals, with the possible exception of a family business in which the business's inventory is also marital property.

138. See id. § 9-306(2) (providing that the security interest travels with the collateral "unless the disposition was authorized by the secured party in the security agreement or otherwise") (emphasis added). Another protection that secured creditors enjoy under Article 9 provides that a creditor's security interest continues in proceeds of collateral. See id. \$ 9-306. When a debtor sells or otherwise exchanges collateral, the creditor's security interest in the collateral continues in the proceeds received 
because everyone married would be subject to the PSA, ${ }^{139}$ creditors and other transferees of interests in marital property would adjust their business practices to account for the primary homemaker's interest in marital property. This change would hardly be revolutionary considering that at least one state already requires both spouses to sign a security agreement that designates consumer goods as collateral. ${ }^{140}$

A final objection to the collateral description is that it might complicate the distribution of assets during a divorce. The premarital security interest should be addressed independently and prior to other marital property distribution at the time of divorce to protect the primary homemaker's interest in receiving a return on her investment in the marital enterprise. Therefore, while the primary homemaker has a security interest in fifty percent of all marital property, the primary wage earner's debt to her will be paid first, and then the remainder of the property will be equitably distributed according to conventional dissolution law. Giving the primary homemaker's security interest priority over the spouse's other claims to assets makes particular sense in those marriages in which there are few assets and many liabilities. In this situation, the premarital security interest can be credited to the primary homemaker to offset any liability she might have for marital debts. ${ }^{141}$ Construed this way, PSAs could significantly benefit low-income and working class women who, particularly if they retain child custody, are most economically vulnerable upon divorce. In sum, PSAs are consistent with commercial law doctrine and would not unduly hinder spouses' use of their property or efficient property division upon divorce. Procedural issues relating to the creation of the PSA are addressed below.

in exchange for the collateral. See id. §9-306(2). Thus, a homemaker/creditor's security interest would continue in money or anything else received in exchange for marital property subject to the security interest.

139. PSAs could be either immutable or default rules. See discussion infra section $\operatorname{III}(C)(3)$. If they are default rules, spouses could execute pre- or post-nuptial contracts limiting or waiving the primary homemaker's security interest in marital property. Even if parties could contract around PSAs, it seems unlikely that a sufficiently high number of them would contract around PSAs that creditors could assume that marital assets were not encumbered. Moreover, creditors, being conservative by the nature of their business, might not be willing to risk the possibility that a prenuptial contract effectively waived the PSA, and thus may well treat all married parties as if the PSA had full effect regardless of any attempt to contract around it.

140. See COLO. REV. STAT. § 4-9-203(2) (1998). This requirement only applies to spouses residing together at the time that the security interest is created.

141. Allowing primary homemakers' security interest to offset their liability for marital debts would address some of the concerns that post-divorce income-sharing proposals only benefit middleand upper-middle class women. See Perry, Alimony, supra note 13, at 2493; see also Nancy C. Staudt, Taxing Housework, 84 GEO. L.J. 1571, 1636-40 (1996) (suggesting that taxing housework would not harm low-income women if Congress enacted a household income tax credit to offset the financial difficulty of paying taxes when household labor is not remunerated with wages). 


\section{Understanding Procedural Mechanics}

To serve the dual goals of valuing women's work and protecting the financial interests of displaced homemakers, PSAs should arise by written agreements, although they could arise by operation of law. They should arise, moreover, when the parties marry, rather than when they divorce. Finally, PSAs would function best if they were default rather than mandatory rules.

1. Method of Creation.-Security agreements can arise either by operation of law or by agreement of the parties. Repair liens, for example, arise by operation of law when a person works on another person's property with the expectation of being paid for the labor. ${ }^{142}$ Liens that arise by operation of law can be created by common law, equity, or statute. ${ }^{143}$ A PSA could similarly arise as a matter of law upon the parties' marriage. PSAs are analogous to repair liens in that a homemaker who devotes her time to domestic labor, in order to benefit her family and maximize her wage-earning spouse's earning capacity, expects to be paid for her efforts by sharing his income stream over the years. When the marriage ends in divorce, she loses out just as a mechanic who repairs a car is harmed when the owner drives away without paying the repair bill. If society makes a social judgment that repair people deserve to get paid, it could just as well make the equivalent choice to remunerate the work of homemakers. Since repair liens arise as a matter of law in recognition of the status of the parties, this analogy is particularly apt for the marital context. ${ }^{144}$ Undoubtedly, a homemaker's contributions to her family's well-being are as valuable as a mechanic's efforts and expenditures in repairing a car.

Despite the similarities between PSAs and security agreements that arise as a matter of law, three important policy reasons militate in favor of requiring the parties to execute the security relationship when they apply for their marriage license. First, a couple's knowledge of the rules that

142. See, e.g.,. CoLO. REV. STAT. §§ 38-20-101 to -116; 1997 Colo. Legis. Serv. H.B. 97-1105 (statutorily creating liens to protect the remuneration of landlords, agistors, common carriers, laborers, molders, and motor vehicle repair garages). See generally 51 AM. JUR. 2D Liens §§ 6, 36 (1998). Repair liens are also known as artisan's liens. Mechanic's liens, in contrast to repair liens, arise to protect the interest of a person who works on real property or fixtures thereon. See, e.g., Colo. REv. STAT. §§ 38-22-101 to -133 .

143. The common law recognizes the interest of a worker who enhances the value of a chattel to be paid for the labor and skill expended. See 1 LEONARD A. JONES \& EDWARD M. WHITE, A TREATISE ON THE LAW OF LIENS: COMMON LAW, STATUTORY, EQUITABLE \& MARTTIME § 731, at 746 (3d ed. 1914) ("By the common law, a workman who by his skill and labor has enhanced the value of a chattel has a lien on it for his reasonable charges, provided the employment be with the consent . . . of the owner.").

144. See U.C.C. $\S 9-102 \mathrm{cmt} .1$ (1995) (describing artisan's liens as "aris[ing] under statute or common law by reason of status and not by consent of the parties"). 
would apply in the event of divorce might prevent them from entering into an ill-fated marriage. ${ }^{145}$ One person, for instance, might find the financial equity imposed by the law unacceptable. Second, a written PSA could be a matter of public record and would put other creditors on notice of the PSAs' encumbrance on marital property in the same manner as secured creditors' publicly filed financing statements under Article 9 provide notice. ${ }^{146}$ Third, policy considerations might dictate that only a select few types of liens arise by operation of law and that credit systems might be compromised by expanding these liens beyond those situations in which people would expect the lien to exist by virtue of the nature of the transaction (such as working on goods for hire). ${ }^{147}$ Because PSAs would designate fifty percent of marital property as collateral, having the PSA arise as a matter of law might impair a creditor's ability to predict, and thus plan for, the existence and scope of the PSA. ${ }^{148}$ On balance, PSAs

145. See Stake, supra note 27, at 447 . As discussed below, however, many couples might disregard the implications of a PSA, believing that their marriage will not be one of the many that end in divorce. See Lynn A. Baker \& Robert E. Emery, When Every Relationship Is Above Average: Perceptions and Expectations of Divorce at the Time of Marriage, 17 LAW \& HUM. BEHAV. 439, 443 (1993) (conducting a study in which couples perceived a low likelihood that they would personally divorce when compared to the likelihood of others).

146. The general rule under Article 9 is that a security interest is perfected (effective against subsequent creditors and other third parties) when the creditor files a financing statement with the state or county. See U.C.C. $\$ \S 9-302,-303,-401$ (1995). Once perfected, the security interest is likely to have priority over other interests in the collateral, such as unsecured interests and interests perfected later. Id. $\S \S 9-301,-312$. Security interests that arise as a matter of law also have priority, id. § 9310 , but do not put the public on notice of their existence in the same way as consensual security interests because they are not a matter of public record. While Article 9 sets out exceptions to the general rule that filing is required to perfect a security interest, these exceptions apply only "where suitable alternative systems for giving public notice of a security interest are available." Id. $\S 9-302 \mathrm{cmt}$. 1 . Certainly, marriages are a matter of public record, which would justify having PSAs be automatically perfected rather than filed with the Secretary of State or county offices, as is required to perfect the security interests in most secured transactions. Automatic perfection would prevent PSAs from clogging up filing systems, and creditors would simply assume any married debtors' property was subject to a PSA unless the couple presented evidence that they had executed an enforceable prenuptial agreement contracting around the PSA.

147. Repair liens, for example, apply to motor vehicles and other personal property that gets repaired or otherwise worked on, while mechanics liens apply to materials and property associated with work done on real property.

148. In the 12 jurisdictions that recognize common-law marriage, the security agreement could arise by operation of law, just as the marriage does. See infra note 373 . These jurisdictions presumably have concluded that unsolemnized and unregistered marriages should count as marriages, so there is no reason to think they should not count for PSAs. Subsequent creditors would merely inquire as to whether the parties held themselves out as married in order to determine whether there was a risk of a marital security interest. This would not unduly burden creditors, as they must similarly inquire in community property jurisdictions whether property is owned by a married person in order to determine whether it is subject to potential claims from that person's spouse. As discussed in note 86, supra, Colorado already requires both spouses to sign security agreements conveying security interests in their consumer goods if they are residing together when the security interest is created. See CoLo. REV. STAT. § 4-9-203(2) (1998). Thus, common-law marriage and community property jurisdictions 
should be executed when a couple applies for a marriage license, at least until spouses and commercial creditors become accustomed to them.

2. Timing.-As already mentioned, PSAs could arise either as a matter of law or through the consent of the parties as evidenced by a signed writing. Regardless of their form, the security agreement should arise at the time of marriage. ${ }^{149}$ The only other alternative is that it attaches at divorce, and doing so would undermine the purpose of the PSA and conflict with the goals of both family and commercial law.

Having PSAs take effect at the beginning of the marriage serves the family law goals of promoting administrative simplicity and marital harmony, and alleviating displaced homemaker indigency in at least four ways. First, spouses file official records with the state upon marriage (and presumably are motivated to share assets and liabilities), and thus it would be easy to include a PSA along with other marriage license materials. Second, the PSA would influence the marriage more clearly and completely if it arises at the beginning of the marriage. If it arises at divorce, parties could not tailor their conduct to achieve the desired distribution of property post-divorce, thus preventing surprises that might result in post-divorce financial strife. Third, executing the PSA at marriage prevents the primary wage earner from disputing the PSA's existence or scope. Fourth, PSAs serve family law goals by preventing some doomed marriages or decreasing marital conflict; executing a PSA at the outset might lead some couples to consider the ramifications of getting married more carefully than they otherwise might. ${ }^{150}$ Realistically, a short conversation about property distribution and income sharing upon divorce is unlikely to affect someone who firmly believes that the marriage will last. Even so, more complete knowledge about the financial implications of divorce might make some

provide models for how PSAs could arise by operation of law without unduly interfering with the interests of other creditors or the spouses themselves.

149. The homemaker/creditor cannot have a valid security interest until the wage earner/debtor has sufficient interest in the collateral for the security interest to attach. See U.C.C. § 9-203(1)(c). The premarital security interest is created and perfected at the time of marriage, but becomes effective as to a particular collateral only when the primary wage eamer has an interest in the collateral. See id. $\$ 204$ (1) \& cmt. 1. Consequently, the primary homemaker's security interest continually attaches to marital property as the primary wage earner acquires interest in the collateral.

150. Publicizing the legal rules governing dissolution to prospective spouses might prevent a small number of ill-fated marriages, or cause fiancées to contract around the default rules, but it could also influence the conduct of spouses during the marriage by, for example, pointing out the economic vulnerability, post-divorce, of those who adopt traditional homemaking roles. See Lynn A. Baker, Promulgating the Marriage Contract, 23 MICH. J.L. REF. 217, 230, 247-48 (1990) [hereinafter Baker, Promulgating]; see also Stake, supra note 27, at 415-25 (describing additional benefits to premarital contracting, such as decreasing marital conflict either by determining conflict resolution procedures ex ante or providing financial security post-divorce so that conflicts due to career changes or relocations are less likely to arise). 
marriages less contentious by informing spouses of their rights and obligations upon marriage. Therefore, having the parties execute a PSA along with their marriage license documentation coheres with the family law goals of promoting harmonious marriage and minimizing financial hardships upon divorce.

Principles of commercial law similarly militate in favor of having couples execute the PSA along with the marriage license. First, secured creditors routinely take a security interest prior to extending credit for the simple reason that doing so maximizes the chance of being repaid. ${ }^{151}$ Because of this routine concern, Article 9 allows the parties to a security agreement to agree on a specific time when the security interest attaches. ${ }^{152}$ The PSA could provide, for example, that the security interest in marital property attaches at the beginning of the marriage, the time of the birth or adoption of the couple's first child, or at some other time when one spouse assumes a disproportionate share of homemaking responsibilities. Second, executing the PSA at the beginning of the marriage would serve the key commercial law function of giving notice to third parties through a central filing system. ${ }^{153}$ Upon execution, the PSA could be filed with the other marriage records and then kept in a separate filing system for PSAs or in a central filing system with other commercial financing statements. Such a filing system would give other creditors notice of the premarital security interest so they could take it into account prior to extending credit. ${ }^{154} \mathrm{~A}$ third commercial reason for executing the

151. This is typically done through a future advances clause, which is authorized in U.C.C. § 9204(3).

152. U.C.C. § 9-203(1) provides that attachment generally occurs when all three requirements are met: the debtor has signed a writing describing the collateral; the creditor has given value; and the debtor has an interest in the collateral. Id. §9-203(1). Section 203(2) allows the parties to specify a later time when they want the security interest to attach. Thus, if the PSA did not provide a time of attachment, attachment would occur as soon as the primary homemaker gave value and the primary wage earner had an interest in the collateral. Id. § 9-203(2). As a result, the security interest would attach repeatedly each time the primary homemaker/creditor gave value in the form of contributing to the primary wage earner/debtor's status as an ideal worker, and each time the primary wage earner/debtor acquired an interest in collateral. See id. §§ 204(1), (3) \& cmt. 5 (explaining that the U.C.C. authorizes after-acquired property and future advances clauses). To the extent that this collateral is "wages, salary or other compensation of an employee" it would be excluded from Article 9 coverage under $\$ 9-104$ (d), but this rule could be altered to allow for premarital security interests in income. Id. \& 9-104(d). The Article 9 rule subordinating secured creditors' rights to those of lien creditors regarding advances made mn $m$ than 45 days after the lien arose would similarly need to be altered to protect primary homemakers whose debt was secured by the PSA. See id. § 9-301(4). Finally, filing the PSA before the wedding would grant the primary homemaker priority over many other claimants under the general rule that the person who filed first generally has priority. See id. § 9$312(5)$ (a) (providing that the first to file or perfect has priority over nonpurchase money security interests, so long as that perfection continues).

153. See WHITE \& SUMMERS, supra note $9, \S 22-4$.

154. Article 9 provides several options for where financing statements should be filed, depending, in part, on the type of collateral. See U.C.C. $\$ 9-401$ (listing filing locations for each class of 
PSA along with marriage license materials is that it would protect the homemaker/creditor. Under the general rule that "first in time is first in right," 155 a PSA filed, or otherwise perfected, at the outset of the marriage will be effective against other creditors who acquire an interest in marital property during the course of the marriage. This priority is essential if the premarital security interest is to have any teeth. Fourth, the nature of the PSA debt and collateral is not inconsistent with executing the PSA with the marriage documents. Under Article 9, a security agreement can cover property that the debtor acquired after the security agreement was executed, and this (and other) property can secure advances the creditor makes after executing the security agreement. ${ }^{156}$ Thus, making PSAs effective at the commencement of the marriage coheres with important commercial law interests. In sum, the premarital security agreement serves both family and commercial law purposes when it is executed at the time a couple applies for a marriage license. This approach allows the PSA to serve its intended dual purpose of valuing women's work in the home and mitigating the financial penalty displaced homemakers suffer upon divorce.

3. Mandatory and Default Rules.-PSAs could either be mandatory or serve as a default rule in the event that the parties fail to enter a prenuptial agreement. Currently, courts enforce premarital agreements in which one party agrees to limit or waive alimony. ${ }^{157}$ Thus, a primary homemaking spouse could waive her rights under a PSA by entering into a prenuptial contract. ${ }^{158}$ Consequently, making PSAs default rules would

collateral and providing three alternative provisions). For simplicity purposes, legislation enacting a PSA could provide that the person processing the marriage license would automatically forward the PSA to the Secretary of State's office for central filing, which is the rule for many types of collateral under U.C.C. \$ 9-401. See id. Because creditors are allowed to prefile financing statements under Article 9, the PSA would be valid even though filed prior to the wedding. See id. § 9-303(1) ("If such steps [(filing)] are taken before the security interest attaches, it is perfected at the time when it attaches.").

155. See id. §9-312(5). A security agreement attaches when it becomes effective between the debtor and creditor. See WHITE \& SUMMERS, supra note 9, § 22-1. However, many creditors want to protect their interest in collateral against subsequent creditors. Creditors do this through a process known as perfection, which generally occurs when the creditor files a financing statement in order to put other creditors on notice of the initial security interest. See id. $\S 22-4$. Article 9 permits a creditor to file a copy of the security agreement as the financing statement as long as it contains all of the contents required to be in a financing statement. See U.C.C. § 9-402(1). Thus, the PSA should include all of these requirements (parties' names, addresses, collateral description, etc.), and it could be automatically entered into a filing system so that anyone interested in the collateral could become aware of the security interest.

156. See U.C.C. § 9-204.

157. See, e.g., Posner v. Posner, 233 So. $2 d$ 381, 385 (Fla. 1970) (rejecting the rule that premarital agreements setting alimony are void).

158. Until recently, courts refused to enforce prenuptial agreements affecting support or property division upon divorce, generally reasoning that such agreements impermissibly encouraged divorce and vitiated the husband's duty to support his wife. See 1 CLARK, supra note $7, \S 1.9$, at 48-49. Nevertheless, in the past few decades courts have reversed this position in response to the availability 
be consistent with current doctrine favoring the enforcement of premarital contracts. ${ }^{159}$

Having explained the skeletal structure of the PSA, the next step is to situate it within the considerable literature seeking to reinvigorate alimony.

of no-fault divorce. See id. at 49 (citing the progressive change in which courts determined that prenuptial agreements fixing maintenance on divorce are valid, provided some requirements are met). These courts concluded that no-fault divorce laws reflect the social progress toward women's equality, thus transforming the state's interest in preserving marriage generally to protecting equality within marriage and larger interests of freedom of contract. See Simeone v. Simeone, 581 A.2d 162, 165 (Pa. 1990) (rejecting the traditional view limiting enforceability of prenuptial agreements, reasoning that "[s]uch decisions rested upon a belief that spouses are of unequal status and that women are not knowledgeable enough to understand the nature of contracts that they enter"); see also Newman v. Newman, 653 P.2d 728, 733 (Colo. 1982) (" $[$ T] here is an assumption in the law that the parties [including the wife] are essentially able to act independently and rationally concerning their . . property interests."). Courts have reasoned that although a prenuptial contract waiving alimony might cause a husband to mistreat his wife safe in the knowledge that he would not have to pay alimony upon divorce, a prenuptial agreement mandating alimony payments might encourage the wife to end the marriage. See Unander v. Unander, 498 P.2d 807, 809 (Or. App. 1972) (refusing to enforce a premarital contract mandating alimony as against public policy), rev'd, 506 P.2d 719 (Or. 1973). However, the Oregon Supreme Court upheld the premarital agreement mandating alimony payments, reasoning that such a result was justified by freedom of contract and the purposes of no-fault divorce. See Unander, 506 P.2d at 721-22 (Or. 1973), overruling Reiling v. Reiling, 474 P.2d 327 (Or. 1970).

159. Allowing spouses to contract around the PSA is consistent with the general trend toward increased legal recognition of spouses' interests in tailoring the legal rules governing their marriage to their particular circumstances. See Mary Anne Case \& Paul G. Mahoney, The Role of the State in Corporations and Marriage 39 (Oct. 2, 1996) (unpublished manuscript, copy on file with the Texas Law Review) (paralleling to a certain degree the evolution of marriage law to the development of corporate law). There are limitations on the enforceability of prenuptial agreements, including requirements of full and fair disclosure between the fiancées, and the absence of fraud, duress, or coercion. See Posner, 233 So. 2d at 385; Volid v. Volid, 286 N.E.2d 42, 47 (IIl. App. 1972). In addition to these requirements, the Uniform Premarital Agreement Act ("UPAA") allows a court to refuse to enforce a premarital agreement if such enforcement would result in one of the spouses becoming eligible for public assistance. UNIF. PREMARITAL AGREEMENT ACT § 6(b) (1983), 9B U.L.A. 369 (1988).

There are arguments for making PSAs immutable. First, premarital agreements tend to deprive women of the rights they would enjoy under statutory default rules. Cf. Atwood, supra note 27, at 133-34 (explaining that women often are disadvantaged by premarital agreements that limit their statutory rights to property division and alimony). Moreover, some women sign prenuptial agreements in circumstances calling into question their full understanding of, and agreement to, the terms of the contract. Under common law, premarital agreements arose out of a confidential relationship, they were closely scrutinized for faimess, and the doctrine of unconscionability applied. See id. at 136. However, the UPAA standard for unconscionability is harder to violate than the common-law one, and therefore enforcement of a premarital agreement might not be enforceable under the common-law rule. See id. at 128-29 (explaining that the UPAA has a narrow standard for unconscionability). Third, it is unfair (specifically to primary homemakers) that courts enforce contracts limiting alimony and property division at divorce, yet refuse to enforce contracts relating to nonmonetary, but nonetheless valuable, contributions to a marriage (such as caring for an ill spouse in exchange for favorable treatment in a will). See Silbaugh, Marriage, supra note 12 (manuscript at 20-28) (contending that courts should either enforce both types of contracts or neither, and opting for the latter approach given the public policy problems of enforcing contractual provisions as they relate to children). Finally, if parties can contract around PSAs, PSAs might not help many primary homemakers who sacrifice market independence to devote attention to caring for their home and children. See Mary Becker, Problems with the Privatization of Heterosexuality, 73 DENV. L. REV. 1169 (1996). On the other hand, few people have the resources or sophistication to execute premarital contracts. 
The PSA has the unique potential to achieve ideological crossover appeal among the varied proposals and critiques aimed at the twin problems of devalued feminine labor and financial distress of displaced homemakers. If PSAs were off-the-rack garments, they might be marketed as "One Size Fits All."

\section{Lack of Consensus Regarding Proposed Solutions}

The financial woes of displaced homemakers could be reduced by retaining no-fault divorce and also increasing the frequency, amount, and duration of alimony awards. Numerous scholars have advocated such an approach. ${ }^{160}$ The next section enumerates and compares these approaches, highlighting the lack of consensus among them. ${ }^{161}$

Both legal economic and cultural feminist proposals for alimony reform share at least one commonality: an interest in rehabilitating alimony to protect women in traditional marriages by remunerating them for their domestic work. Otherwise, there is considerable distance between the various proposals. For example, some would terminate the payments upon remarriage, while others would not. ${ }^{162}$ Some support traditional gender roles, while others do not. ${ }^{163}$ Perhaps because of these differences,

160. See supra note 26 and accompanying text.

161. Cf. BECKER, supra note 16, at 38-39 (defending the efficiency of gendered specialization in domestic and market labor); Kay, Equality, supra note 26, at 78-81, $89-90$ (advocating that the continued dependence of women on the financial support of their husbands during and after marriage perpetuates the vulnerability of women at divorce).

162. Compare Starnes, Divorce, supra note 4, at 138 (arguing that buyout payments should not terminate with remarriage), with ALI, PRINCIPLES, supra note 108, §§ 5.08, 5.10 (calling for the termination, in most instances, of alimony payments when the recipient cohabits-with an opposite or same-sex partner-or remarries).

163. Compare Carbone, Reply, supra note 58, at 1493 (proposing a restitution-based theory of alimony that will "encourage women to bear primary responsibility for child-rearing and to make sacrifices that will enhance husbands' careers"), with POSNER, ECONOMIC, supra note 16, at 147-48 (conceptualizing alimony as a form of severance pay to help maintain the wife's former standard of living). Liberal feminist proponents are unlikely to support measures that reinvigorate alimony, $c f$. Kay, Equality, supra note 26, at 78-81, 89-90, contending that alimony disserves women because it discourages them from becoming ongoing participants in the wage labor force and reinforces traditional gender roles. See Kay, Appraisal, supra note 26, at 30. Kay also has expressed support for postdivorce income sharing when one spouse has incurred a loss by virtue of her investments in marital sharing behavior. See Kay, No-Fault, supra note 19, 32-34 (arguing for reforms to methods of calculating "reimbursement alimony" so that it accurately reflects a spouse's opportunity costs); Kay, Appraisal, supra note 26, at 315 (arguing that, at divorce, a supporting spouse should receive compensation for "the opportunity cost of having foregone her own education to improve her earning capacity, as well as wages foregone by the student spouse during the education years that would have enhanced the family's standard of living"). In defending the importance of continuing to use lost opportunity cost analysis, Kay noted:

I do not believe we have yet come to the historical moment when I would conclude that there is no need to use "lost opportunity cost" analysis to justify compensating "modern women who forego promising career prospects to care for children" upon divorce. . . . I envision a long and arduous period of fundamental social change before women can 
which often turn on ideological divides, no single proposal has received widespread support. Ira Ellman critiques contract and partnership analogies forwarded by Margaret Brinig and June Carbone, ${ }^{164}$ and some feminists critique Ellman's human capital theory as designed to meet only the needs of higher-status women who abandon traditionally male careers for homemaking. They also argue that Ellman's theory ignores the ways in which primary homemaking confers a valuable benefit to both the family and the primary wage earner's career. ${ }^{165}$ Moreover, liberal feminists resist rehabilitating alimony at all, let alone in a sweeping manner. ${ }^{166}$

One reason for this lack of unanimity concerning alimony is divergence among the normative assumptions made by legal economic scholars and liberal, cultural, and radical feminist scholars. These ideological gaps obscure the common ground shared by most of the proposals: a desire to value women's work done within marriage by remunerating primary homemakers for it at divorce. PSAs have the potential to cross over these ideological divides to accomplish this shared goal.

PSAs share some common ground with legal economic as well as cultural, liberal, and radical feminist approaches to alimony, and PSAs also refine and improve these models. PSAs improve upon the legal economic models because they account for homemaker contributions to family wealth rather than view them as just sacrifices of her human capital. ${ }^{167}$ Furthermore, PSAs are more desirable than the cultural feminist partnership models because they replace judicial enforcement with self-help remedies, account for primary caretakers' post-divorce contributions to the primary wage earners' income, and counteract gender hierarchy in

fairly be held fully responsible for the financial consequences of their choices concerning intimate relationships and childrearing.

Herma Hill Kay, Commentary: Toward a Theory of Fair Distribution, 57 BROOK. L. REV. 755, 764-65 (1991).

164. See Ellman, Theory, supra note 11, at 13-40 (arguing that marital relationships do not correspond with the contract model).

165. See Silbaugh, Marriage, supra note 12 (manuscript at 36-39); Singer, Alimony, supra note 4 , at 2444-48. Other feminists critique economic theory and methodology as being too narrow to encompass the diverse motives for marital behavior, and inadequate to protect young mothers divorced after short marriages. See Estin, Efficient, supra note 26, at 31-33; Estin, Maintenance, supra note 26 , at 744.

166. See Kay, Equality, supra note 26 , at 80.

167. PSA calculations are based on the difference between spouses' incomes at the time of divorce, length of the marriage, and age of the children, rather than on specific marital sharing behaviors and thus quantify both homemaker loss of human capital and wage earner increase in human capital. See infra subsection III(A)(2)(b). In this way, PSAs account for critiques of Ellman's The Theory of Alimony. See Carbone, Reply, supra note 58, at 1481 (criticizing "Ellman's unwillingness to recognize benefits other than children or enhanced income"); Carl E. Schneider, Rethinking Alimony: Marital Decisions and Moral Discourse, 1991 BYU L. REV. 197, 235 (discussing the shortcomings in Ellman's alimony theory); Singer, Alimony, supra note 4, at 2444-45 (discussing problems with the human capital approach). 
marriage with the commercial hierarchy of creditor over debtor. Finally, PSAs are more concrete than the radical feminist proposals, yet still retain the potential to contribute to a changed understanding of family. In short, PSAs have the potential to bridge the ideological gulfs between liberal, cultural, and radical feminist, as well as legal economic divorce reform proposals.

\section{One Size Fits All}

Commercializing marriage through PSAs could alleviate many of the financial problems of displaced homemakers by valuing the domestic labor they perform for their families. As such, PSAs improve on proposals justifying alimony, in that PSAs have the unique potential to transcend ideological boundaries by accommodating law and economics scholars, as well as liberal, cultural, and radical feminist theorists. Perhaps PSAs' crossover appeal stems from the intuitive appeal of treating primary homemakers as lenders. Commentators as ideologically diverse as Richard Posner and Joan Williams have analogized a homemaker's financial claims upon divorce to those of a commercial lender. ${ }^{168}$ This Part analyzes a range of theoretical approaches after briefly addressing the implications of transporting a doctrine from the private market realm into the private family realm. ${ }^{169}$

Compelling arguments suggest that the boundaries between public and private, and family and market, are not as fixed as is often assumed. ${ }^{170}$

168. Both Posner and Williams analogize the homemaker to a commercial lender who extends credit in order to allow a student to pursue his education, reasoning that a person who puts her spouse through school is as entitled to repayment as a commercial lender. See POSNER, ECONOMIC, supra note 16 , at 163 \& $n .1$ (questioning whether an "equity-type investor" might be a better analogy than a lender); Williams, Coverture, supra note 6 , at 2287. Becker extends this concept, suggesting that parents lend money to their children, and that children repay this debt when the aging parents need the money. See BECKER, supra note 16, at 5-6. While PSAs do not cast parents and children as creditors and debtors, they do apply this model beyond the student-spouse context, arguing that the primary homemaker extends credit to support other stages in the primary wage earner's income development, not just for formal education.

169. If the public/private possibilities are conceived as being on a continuum, the family would be on the extreme of private institutions (at least rhetorically, see Frances E. Olsen, The Myth of State Intervention in the Family, 18 U. MICH. J.L. REFORM 835, 835 (1985) [hereinafter Olson, Myth]), while political institutions such as legislatures would be on the public extreme. In between these extremes is the market, which is both more public than the family and more private than the state. PSAs reflect the mutability of commercial constructs, appearing private in relation to current statutory rules governing asset distribution at divorce, and seeming public in comparison to the current understanding of homemaking as done for love rather than for money. See Silbaugh, Labor, supra note 2 , at 4 (noting that "the U.S. legal system conceptualizes housework as solely an expression of affection," and not as "value-producing labor").

170. See, e.g., Frances E. Olsen, The Family and the Market: A Study of Ideology and Legal Reform, 96 HARV. L. REV. 1497, 1568-69 (1983) [hereinafter Olsen, Family] (criticizing the dichotomies between "market" and "family"); Rhode \& Minow, supra note 45, at 194 ("[F]amily roles 
PSAs illustrate this permeability by applying a commercial model of securing repayment of loans to the family law problem of displaced homemaker indigency that results from the noncommodification of homemaking labor. This migration could serve several functions, including highlighting economic aspects of marriage and revealing the contributions of homemaking labor to family wealth. By importing a private market model of remuneration, PSAs thus reverse the usual pattern in which the private nature of the family is used to justify the refusal to pay women for work done for their families, reasoning that the work is done for love rather than for money. In short, PSAs exploit the mutability of the distinction between public and private to the benefit of homemakers, a marked improvement from the current doctrine, which exploits it to the detriment of homemakers. ${ }^{171}$

Home and marketplace are thought of as private in different ways. Since the early nineteenth century, the home has been rhetorically constructed as a feminine sphere of altruistic, intimate, and spiritually uplifting relations where men could take refuge from the "competitive, self-seeking" realm of the market. ${ }^{172}$ State-mandated separation of the private (domestic and commercial) spheres from each other, and the private spheres' separation from the public (political) sphere has perpetuated a gendered understanding of marriage in which men devote primary attention to wage labor, women devote primary attention to domestic labor, and the state ratifies patriarchal power within the family through a doctrine of noninterference. ${ }^{173}$ This reasoning long justified denying many women access to public (political or commercial) life by declaring that their divinely mandated domestic duties were inherently inconsistent with female participation in the market or politics. ${ }^{174}$ To maintain separate

shape and are in turn shaped by state policies and market forces . . . . Our concern is to develop principles that are sensitive to the interconnections between public and private and that are committed to advancing both gender equality and the quality of family life.").

171. See Katharine Silbaugh, Commodification and Women's Household Labor, 9 YALE J.L. \& FEMINISM 81, 84, 83-84 (1997) [hereinafter Silbaugh, Commodification] (noting that the refusal to view housework as economic labor is detrimental to women's economic welfare and that the standard counterargument is that economic analysis of housework is "inconsistent with a vision of personhood or human flourishing"); Silbaugh, Labor, supra note 2, at 61 (explaining that courts undervalue housework in divorce proceedings because they view it as a private activity of the home).

172. See Siegel, Home, supra note 5, at 1092-93 (linking this devaluation to the growth of a wagebased economy for male labor in place of an agrarian one).

173. See Olsen, Myth, supra note 169, at 848-55 (explaining the link between purported nonintervention and the persistence of traditional family structures).

174. White nineteenth-century feminists often exploited the rhetoric of separate spheres to justify women's rights, such as the antebellum joint property claims that women's domestic labor was sufficiently valuable (economically and socially) and that women should be entitled to fully one-half of the marital estate upon death of their husbands. See Siegel, Home, supra note 5, at 1113. Legislatures rejected these proposals, instead adopting earnings statutes that gave wives a property interest in their 
spheres, family, market, and the state were constructed as mutually exclusive. ${ }^{175}$

This purported separation between family, market, and politics is mythical; the state influences family life even when it claims not to be intervening, ${ }^{176}$ and it often openly proclaims its centrality to family life. ${ }^{177}$ Moreover, the market is more public than it initially seems; commerce always occurs in the shadow of government-generated law. Numerous legal rules-such as Article 9 of the Uniform Commercial Code and its judicial interpretations-circumscribe the contents and enforcement of commercial contracts. ${ }^{178}$ In sum, categorizing a transaction as private is largely a rhetorical description of how it differs in degree rather than in kind from other, more governmental, activities. We nevertheless speak of public and private law as meaningful categories despite their evident fluidity. ${ }^{179}$

Perhaps this fluidity has been exploited to the detriment of women, specifically by designating work done in the home as private, in a special

work for wages. Courts, however, construed this entitlement narrowly, so that a husband remained entitled to his wife's wages unless she declared them to be for her separate account rather than for the family, reasoning:

The bare fact that [a wife] performs labor for third persons, for which compensation is due, does not necessarily establish that she performed it, under the act of 1860 , upon her own separate account. The true construction of the statute is that she may elect to labor on her own account ... but in the absence of such an election ... the husband's common law right to her earnings remains unaffected.

Id. at 1185 (quoting Birkbeck v. Ackroyd, 74 N.Y. 356, 358 (1878)). Another court reasoned that wives could not be compensated for work done for their families because doing so would "discharge the wife from her common-law and scriptural obligation and duty to be a 'help-meet' to her husband." Id. at 1183 (quoting Mewhirter v. Hatten, 42 Iowa 288, 291-92 (1875)). This cult of domesticity, however, did not apply in the same way to women of color. African-American women, for example, have always participated in the market to a greater extent than their white counterparts. See Brown, supra note 13, at 793 (describing U.S. COMM'N ON CIVIL RIGHTS, STAFF REPORT ON THE ECONOMIC STATUS OF BLACK WOMEN: AN EXPLORATORY INVESTIGATION 100 (1990), which found that married African-Amercian women contribute approximately $40 \%$ of household income, compared to married white women, who contribute only $29 \%$ of their household income); Perry, Alimony, supra note 13 , at $2489 \&$ n. 40 (detailing the historically high participation rate of black woman in the workforce); see also CENSUS, INCOME, supra note 6, at 26-27 tbl.7 (reporting a lower income gap between AfricanAmerican males and females as compared to their white counterparts).

175. See Olsen, Family, supra note 170, at 1498 n.1.

176. See Olsen, Myth, supra note 169, at 842 (stressing the state's role in defining families).

177. See, e.g., Posner v. Posner, 233 So. $2 \mathrm{~d} 381,383$ (Fla. 1970) (“' 1 ]t has frequently been said that in every divorce suit the state is a third party whose interests take precedence over the private interests of the spouses."); supra notes 51-56 and accompanying text (discussing the state definition of marriage as opposite-sex in the Defense of Marriage Act).

178. See, e.g., U.C.C. $\$ 9-504$ (1995) (establishing creditors' rights and duties upon foreclosure, repossession, and disposal of collateral).

179. The dictionary definition of commerce nicely illustrates the common ground shared by (relatively public) commerce and (relatively private) intimate personal relations. Of the four meanings, two are associated with business, and two with intimacy. See supra note 1. 
way that precludes compensation. ${ }^{180}$ In the alternative, maybe this same fluidity can take us in the opposite direction, toward valuing female domestic labor by submitting it to models of remuneration used in the market. By importing commercial models into marriage, perhaps PSAs could achieve what 150 years of feminist activism and scholarship have not: an increased valuation of women's work in their homes. PSAs are just the latest in a long stream of proposals designed to serve this very purpose. This Part briefly outlines each ideological approach to marriage and alimony, then suggests that proponents of each position might find that PSAs further many of the goals that give rise to their calls for change to the alimony rule.

\section{A. Legal Economic Approaches}

Generally, most legal economists would make either positive or normative claims that law is or should be efficient. ${ }^{181}$ In the family law context, legal economists have focused on how the contractual elements of marriage and human capital considerations dictate that divorce law should promote efficiency by deterring opportunistic behavior. Traditionalist legal economists contend that conventional gender roles are efficient and that the law should reimburse marital sharing behavior, reasoning that doing so would encourage marital sacrifices and discourage opportunistic exploitation of those sacrifices. ${ }^{182}$

\section{Legal Economic Analysis of Marriage and Alimony.}

a. Contractual analysis of marriage.-Focusing on the contractual elements of marriage is central to economic approaches addressing the issue of alimony. Becker, ${ }^{183}$ Bolin, ${ }^{184}$ Brinig, ${ }^{185}$

180. See Siegel, Home, supra note S, at 1077, 1092-93; Silbaugh, Commodification, supra note 171 , at 95 (arguing that differences in treatment between home labor and wage labor have led to a "tendency to leave women without cash in the name of non-commodification"); Susan Sterett, Serving the State: Constitutionalism and Social Spending, 1860s-1920s, 22 LAW \& SoC. INQUIRY 311, 315-16 (1997) (explaining the distinction in the courts between "[a]ctivity for public benefit, which could be rewarded as service [and] . . . dependency, which could be granted charity," and characterizing mothers as dependents rather than as public service workers).

181. Law and Economics encompasses several schools of thought, including both the Chicago School associated with political conservatism and a single-minded focus on efficiency, and the younger New Haven School, which tends to be more agnostic about efficiency as a legal goal and also considers other theoretical perspectives. See Minda, supra note 35, at 605-07.

182. See infra subsection $\operatorname{IV}(\mathrm{A})(1)(\mathrm{b})$.

183. See BECKER, supra note 16, at 30-31 (stating that wives should demand contracts from their husbands).

184. See Bolin, supra note 26 , at 494 (viewing marriage as a contingent contract).

185. See Brinig \& Carbone, Reliance, supra note 26 , at 856 (discussing the protection of the reliance interest in domestic relations law); Carbone \& Brinig, Rethinking, supra note 26, at 957,977 
Carbone, ${ }^{186}$ Cohen, ${ }^{187}$ Landes, ${ }^{188}$ Ellman, ${ }^{189}$ Parkman, ${ }^{190}$ Posner, ${ }^{191}$ and Rasmusen and Stake ${ }^{122}$ share this emphasis, and all use economic theory to some extent. The contract model of marriage suggests that marriage should be legally treated as a contract, albeit a special kind of contract. ${ }^{193}$ Some commentators distinguish between the marriage contract under fault-based and no-fault divorce, preferring the fault-based marriage contract, which entitles the nonbreaching party to damages for breach upon divorce. ${ }^{194}$ These legal economists argue that no-fault

(analogizing divorce to the breach of a commercial contract). Both Brinig and Carbone are perhaps less extreme contractarians regarding marriage than some traditionalist legal economists. For example, Brinig has championed what she calls covenant marriage as a midway point between contractual and status analyses of marriage. See Margaret F. Brinig, Status, Contract and Covenant, 79 CORNELL L. REV. 1573, 1596 (1994) (reviewing MILTON C. REGAN, JR., A REVIEW OF FAMILY LAW AND THE PURSUIT OF INTIMACY (1993)) (using the idea of a covenant in addition to contract to explain aspects of marriage); Brinig, Comment, supra note 71, at 2463-65 (rejecting the "Chicago School law and economics efficiency-seeking ventures" model of marriage in favor of a quasi-contractual model grounded on "self-sacrifice, sharing, outward-looking behavior," dubbing this model covenant marriage). Brinig also challenges traditionalist defenses of gendered specialization of labor as efficient, contending that specialization results in diminishing returns and traditionalist analysis ignores "psychic costs" of specialization. See Brinig, Comment, supra note 71, at 2472 . Carbone has similarly turned her focus from marital relations to the central role of children in primary homemakers' economic straits post-divorce, analyzing alternative visions of community and family that depart considerably from arm's length contractarian models. See Carbone, Income, supra note 26, at 362-63.

186. See Brinig \& Carbone, Reliance, supra note 26, at 856 (discussing the protection of the reliance interest in domestic relations law); Carbone, Reply, supra note 58, at 1469-70; Carbone \& Brinig, Rethinking, supra note 26, at 957, 977 (analogizing divorce to the breach of a commercial contract).

187. See Cohen, Best, supra note 26, at 271 (suggesting that social and religious aspects of marriage do not change the fact that "the marriage agreement is also a contract").

188. See Landes, supra note 26 , at 40 ("Alimony increases the flexibility of the contractual agreemeni, by substituting an enforceable claim to future transfers for a current transfer . . . .").

189. See Ellman, Theory, supra note 11, at 13-14 (focusing on the failure of the contract model to accurately describe the way law treats marriage). Yet he proposes a contract-like remedy to reimburse spouses for their sacrifices on behalf of the marriage. See id. As such, his model may be more accurately characterized as quasi-contractual, and thus distinguishable from models which view marriage itself as contractual.

190. See Parkman, supra note 4, at 96-97 (analyzing the similarities of marriage and contracts).

191. See POSNER, ECONOMIC, supra note 16, at 164-65 (treating a divorce similar to a breach of contract).

192. See generally Rasmusen \& Stake, supra note 27, at 454 (noting that contractual principles have not been applied to the area of marital law). For a critique of this approach, see generally Abrams, supra note 27.

193. See BECKER, supra note 16, at 30-31; Parkman, supra note 4, at 96-97. Lloyd Cohen is perhaps most explicit in his contractual approach to marriage, explaining that although marriage has religious, social, cultural, psychological, and philosophical elements, "the marriage agreement is also a contract." Cohen, Best, supra note 26, at 271 . He limits his discussion to contractual issues associated with the "peculiar contract" of marriage, see id., and goes on to analogize marriage to an employment contract in its lack of specific detail, on-going nature, and mutual promises relating to future streams of services. See id. at 272-73.

194. See, e.g., Cohen, Best, supra note 26, at 274-75 (noting that even in no-fault divorce jurisdictions, courts consider fault when allocating alimony and other resources); Parkman, supra note 4, at 105 (proposing default damages of specific performance upon breach of the marriage contract). 
divorce changed marriage into an employment-at-will contract that allowed either party to exit without penalty, thereby vitiating any claim to damages for breach. ${ }^{195}$ Margaret Brinig and Steven Crafton, for example, contend that this transformation of the marriage contract increased the incidence of domestic violence by removing post-divorce penalties against husbands who abuse their wives. ${ }^{196}$ Other economic theorists attribute displaced homemaker indigency to this change, arguing that no-fault divorce encourages primary wage earners to engage in opportunism by enjoying the marital investments made by the primary homemakers early in the marriage and then exiting before making significant investments themselves. ${ }^{197}$

Bolin, Carbone, and Brinig all depart from this traditionalist contractual model of marriage. They contend that marriage is a contractual relation justifying the use of contractual remedies such as reliance and restitution to compensate homemakers for their losses upon divorce. ${ }^{198}$ This brief summary illustrates the wide variety of possible approaches to alimony among those who adopt legal economic descriptions of marriage as a contract that operates most efficiently when the law deters spousal opportunism.

b. Traditionalist view of gendered roles as efficient.-The second element common to traditionalist legal economists is the contention that the specialization of gender roles in marriage is efficient. ${ }^{199}$ Some feminist

195. See Cohen, Best, supra note 26, at 299 (finding problems with unilateral divorce that does not involve property settlements); see also POSNER, ECONOMIC, supra note 16, at 164 (justifying alimony as severance pay for termination of an employment contract). It is important to note that this insight differs from saying that one spouse employs the other, because the central economic premise is that they employ each other. See id. at 156-57 (distinguishing marriages from commercial partnerships on the ground that marital wealth is not distributed based on the value of each spouse's contributions and that tasks are not monitored in a hierarchical, bureaucratic manner).

196. See Margaret F. Brinig \& Steven M. Crafton, Marriage and Opportunism, 23 J. LEGAL STUD. 869, 892-95 (1994). For a critique of this argument, see generally Ira Mark Ellman \& Sharon Lohr, Marriage as Contract, Opportunistic Violence, and Other Bad Arguments for Fault Divorce, 1997 U. ILL. L. REV. 719, 762-63 (criticizing Brinig and Crafton's research for providing "poor analysis" and using "defective data").

197. See, e.g., Cohen, Best, supra note 26, at 287 (describing the imbalance over time of the benefits each spouse receives from the marriage and the resulting incentives to breach the marriage contract).

198. See Bolin, supra note 26, at 494 (arguing that the treatment of marriage as a contract is fruitful because investments in the marriage aid in determining spousal support at the time of divorce); Brinig \& Carbone, Reliance, supra note 26, at 881 (discussing the increasing complexity of the reliance interest in modern marriage); Carbone, Reply, supra note 58, at 1466 (supporting restitution as an appropriate basis for financial allocations at divorce); Carbone \& Brinig, Rethinking, supra note 26, at 986 (noting that emerging models of divorce are restitution-based).

199. See, e.g., BECKER, supra note 16, at 37 ('[B]iological differences in comparative advantage between the sexes explain not only why households typically have both sexes, but also why women have usually spent their time bearing and rearing children and engaging in other household activities, whereas men have spent their time in market activities."); POSNER, ECONOMIC, supra note 16, at 156- 
commentators, including those who use economic efficiency to evaluate family law doctrine, disagree, arguing that specialization arguments ignore nonmonetary costs and the law of diminishing returns, and that efficiency of the status quo does not translate into efficiency of specialization in gender roles. ${ }^{200}$ Nevertheless, traditionalist legal economists remain convinced that gendered specialization of labor is more efficient than both spouses actively participating in both spheres. ${ }^{201}$

\section{c. Incentives for opportunism under no-fault rules.-Most legal} economic analysis suggests that the current state of divorce law encourages opportunism and is therefore inefficient. Cohen's work most clearly articulates this argument that no-fault divorce harms primary homemakers by creating incentives for primary wage-earner opportunism. ${ }^{202}$

Cohen posits that men and women play gender roles in marriage because doing so is economically efficient, and perhaps biologically determined. ${ }^{203}$ Thus, women make marriage-specific investments early in marriage, such as specializing in the domestic rather than market labor (by, for example, taking primary childcare responsibility) and foregoing the opportunity to marry someone else. Men, he argues, have little to invest in the early years of marriage and instead invest in their personal human capital. ${ }^{204}$ As the marriage progresses, according to Cohen, tile wife's value on the remarriage market declines (even more so if she has children), as do her options to compete in the wage labor market. ${ }^{205}$ This pattern, traditionalist legal economists contend, encourages opportunism by the

57; Ellman, Theory, supra note 11, at 46-48; Parkman, supra note 4, at 95; see also Cohen, Rhetoric, supra note 53, at 2284 (claiming that traditional gender roles benefit women economically).

200. See, e.g., Brinig, Comment, supra note 71, at 2469-73; Estin, Efficient, supra note 26, at 3-4; Singer, Alimony, supra note 4, at 2437-53.

201. See, e.g., POSNER, ECONOMIC, supra note 16, at 156.

202. See Cohen, Best, supra note 26, at 287. Cohen contends:

[T] he marriage contract promises gains to both the parties who enter into it. As a rule, men tend to obtain gains early in the relationship when their own contributions to the marriage are relatively low and that of their wives relatively great. Similarly, later on in the marriage women tend as a general rule to obtain more from the contract than do men. The creation of this long-term imbalance provides the opportunity for strategic behavior whereby one of the parties, generally the man, might find it in his interest to breach the contract unless otherwise constrained.

Id. Cohen clarifies some of his baseline defenses of traditional gender roles in marriage in a more recent article. See generally Cohen, Rhetoric, supra note 53, at 2284-85.

203. See Cohen, Rhetoric, supra note 53, at 2285-86 ("Men and women are, different. . . . The male and female role in procreation differs and, probably for that reason, so does their relation to children. Whether for biological reasons, as I believe, or cultural reasons, as many feminists believe, most women need no urging to nurture their children.").

204. See Cohen, Best, supra note 26, at 287.

205. See id. at 273 ( $"[\mathrm{~W}]$ omen in general lose value in the marriage market relative to men over time. The stream of services offered by women in the marriage market are more front-end loaded. Consequently, a woman's capital asset value as a wife is consumed more quickly than . . . a man's . . . as a husband."). 
husband by allowing him to benefit from the wife's early-marriage contributions to his earning potential and then leave. ${ }^{206}$ A divorce rule imposing exit costs (i.e., alimony) would deter this opportunism. ${ }^{207}$ Much of the traditionalist legal economic analysis of alimony echoes Cohen's basic premises but in less explicit economic terms. Perhaps the most influential of the current, softened, economic justifications for alimony is Ellman's theory of marital sharing behavior.

d. Incentives for marital sharing behavior.-Ellman's theory of marital sharing behavior merits separate analysis for two reasons: (1) it has generated widespread commentary; ${ }^{208}$ and (2) like the PSA, it both draws on and departs from various parts of traditionalist legal economic approach to alimony. Ellman's theory of alimony compensates marital sharing behavior, which diminishes a primary homemaker's human capital. ${ }^{209}$ He diverges from other legal economists by rejecting contract and partnership models of marriage, ${ }^{210}$ but he adheres to economic analysis in justifying alimony as a contract-like remedy in the form of reimbursement for primary homemakers' financially rational sacrifices of human capital. ${ }^{211}$ Financially rational sacrifices, under Ellman's theory, include foregoing a career opportunity to accommodate the other spouse's career. ${ }^{212}$ Only fifty percent of human capital losses due to childcare, however, are reimbursed under Ellman's theory because he deems these sacrifices financially irrational. ${ }^{213}$ Homemakers receive fifty percent of the lost opportunity cost in deference to the "traditional ideal" of having parents care for their own children. ${ }^{214}$ Ellman's focus on the human capital costs of marital-

206. See POSNER, ECONOMIC, supra note 16 , at $163 \mathrm{n} .2$ (citing a study indicating that homemakers generate as much as $40 \%$ of the household's full income); Landes, supra note 26 , at 40 (claiming that the time wives spend in household production enables their husbands to increase their market eamings).

207. Cohen argues that no-fault divorce perversely encourages the husband to act opportunistically, taking the best years of his traditional wife's life by divorcing and leaving his wife with slim options on both the remarriage and job market. See Cohen, Best, supra note 26, at 285 . While the bulk of Cohen's analysis seems aimed at critiquing no-fault divorce, and he initially sees fault as a "powerful" solution to the problems of male opportunism in marriage, he stops short of endorsing a return to faultbased divorce because of the impossibility of a specific performance remedy. Id. at 299-300.

208. See, e.g., Carbone, Reply, supra note 58, at 1497-98; Singer, Alimony, supra note 4, at 2438-51; Williams, Coverture, supra note 6, at 2254-57 (all criticizing Ellman's proposed use of alimony as a means of reallocating the costs of divorce as too narrow because it either assumes or encourages a degree of marital specialization).

209. See Ellman, Theory, supra note 11, at $49-53$ (suggesting that alimony can be a method for compensating spouses whose marital investment left them less able to recover from divorce than their partners).

210. See id. at 9-12.

211. See id.

212. See id. at 58-60.

213. See id. at 71-72.

214. See id. at 71-73. Nor would Ellman have the courts compensate a primary homemaker for losses due to picking this spouse rather than another, or for nonfinancial losses. Id. at 56-58. In a 
sharing behavior, along with his assumptions regarding self-interest and wealth maximization, place him in the legal economic camp, despite his disagreement with contract models of marriage.

2. Legal Economic Support for Premarital Security Agreements.Legal economic proposals justifying alimony generally do one or more of the following four things: (1) treat marriage as more contractual than status-related in nature; ${ }^{215}$ (2) encourage gendered specialization of labor as efficient; ${ }^{216}$ (3) minimize incentives for opportunism; ;17 and (4) reward marital sharing behavior. ${ }^{218}$ PSAs can serve all four of these functions.

First, PSAs focus on contractual elements in marriage by importing a contractual debtor-creditor model from commercial law into family law. Legal economists' view of marriage as contractual (rather than statusoriented) justifies the New Home Economics ${ }^{219}$ by equating family with other contexts that are already governed by contract and economic principles; if, instead, marriage were treated as a status, religious and other moral arguments would hold more sway than economic ones. Understanding marriage in contractual terms legitimizes the use of commercial models to resolve problems in divorce law. ${ }^{220}$ Thus, the contractual element of PSAs makes them particularly attractive to law and economics scholars.

This contractarian approach to marriage may lead legal economists to support PSAs only if they are created by consent through a signed writing

subsequent article, he defended his theory's exclusion of financially irrational marital sharing behavior from being compensable upon divorce. See Ira Mark Ellman, Should The Theory of Alimony Include Nonfinancial Losses and Motivations?, 1991 BYU L. REV. 259, 288-90.

215. See, e.g., Cohen, Best, supra note 26, at 272 (analogizing the marriage contract to an employment contract); Parkman, supra note 4, at 96 ("The creation of the marriage agreement is similar to the requirements of a commercial contract, since the agreement must be voluntary and it can be annulled if the agreement of one party was obtained by fraud or force."); Rasmusen \& Stake, supra note 27, at 502 (suggesting that premarital contracting would allow spouses to tailor terms to suit their situation). Despite Ellman's critique of contract or restitution as a justification of alimony, see Ellman, Theory, supra note 11, at 13-33, Bolin and Carbone have convincingly argued that Ellman's analysis is, in fact, contractual. See Bolin, supra note 26, at 494 (claiming that Ellman's rule for alimony is close to "the theory of breach of contract if divorce is regarded as a breach by one party" (emphasis in original)); Carbone, Reply, supra note 58, at 1472 (arguing that only expectation damages provide the advantages of Ellman's theory, and expectation damages are contractual in nature).

216. But see Carbone, Reply, supra note 58, at 1490-91 (criticizing Ellman's conclusion that gendered specialization is efficient as premised on the efficiency of the status quo of gender roles).

217. See, e.g., Cohen, Best, supra note 26, at 287-95 (asserting that the recognition of the natural allocation of quasi-rents between spouses creates new mechanisms for preventing opportunism by spouses).

218. See, e.g., Ellman, Theory, supra note 11, at 53-73.

219. See supra text accompanying notes $183-93$.

220. See, e.g., POSNER, ECONOMIC, supra note 16, at 158-65 (applying contractual principles to the formation and dissolution of marriage). 
(rather than by operation of law), since a contractarian approach might require unequivocal manifestation of assent to the terms of the contract. ${ }^{221}$ However, some legal economists might support PSAs even if they arose by operation of law. This type of lien, which could be called a homemaker's lien, would be particularly appropriate in the marital context, since marriage is also a contract created by operation of law. ${ }^{222}$ Regardless of whether PSAs arose by a signed writing or by operation of law, they would likely accord with economic analysts' focus on the contractual elements of marriage.

PSAs also satisfy traditionalist legal economic approaches to alimony by creating incentives for gendered specialization of labor. If primary caretakers had security interests in marital property to protect them in the event of divorce, then caretaking would be remunerated, providing an economic incentive to engage in that activity. Becker, Cohen, and other traditionalist legal economists contend that such specialization may be biologically based, compelling women to specialize in domestic work. ${ }^{223}$ If women are biologically driven to their traditional gender roles, then they will continue to specialize in household labor under PSAs, and the law will further the goal of such efficient specialization. Thus, traditionalist legal economists should like PSAs for making family law more efficient by tailoring it to biological imperatives. ${ }^{224}$

221. See generally Richard A. EPSTEIN, Simple RUles FOR A COMPLEX WORLD 53 (1995) (arguing that voluntary exchange is one of six simple rules governing law).

222. Some legal economists would prefer a truly consensual marriage contract to the current one, in which parties are often ignorant of the contract's terms until dissolution, see Baker, Promulgating, supra note 150, at 247-49, and also support measures that would familiarize fiancées with the rules governing property division upon divorce. See, e.g., Rasmusen \& Stake, supra note 26, at 460-62 (suggesting that "premarital discussions shift away from the terms of divorce and toward the grounds of settlement or the terms of wedlock"); Stake, supra note 27, at 415-25 (supporting prenuptial agreements as a means for allowing couples to "structure the economic consequences of [their] future behaviors" in light of the potential for divorce).

223. See supra note 199.

224. Feminist legal economists, such as Brinig, Carbone, and Singer, who contest the efficiency of gendered role specialization might also appreciate PSAs if PSAs disaggregated gender and sex. For example, caretaking might be most efficiently done by patient, kind people who enjoy children, rather than those with XX chromosomes. PSAs might create incentives to specialize in homemaking and market labor, but do so in such a way that either men or women could engage in this gendered female behavior. This kind of arrangement would be gendered specialization, rather than sex-based specialization. In a couple, one spouse would be gendered male (specializing in market labor), while the other would be gendered female (specializing in homemaking). PSAs, however, in no way require that a spouse's sex match his or her gender; either men or women could specialize in homemaking. See Williams, Deconstructing, supra note 32, at 839 (supporting legal rules that are "sex-but not gender-neutral" and thus do not "reinforce the traditional assumption that adherence to gender flows "naturally' from biological sex" (emphasis in original)). Posner acknowledges that either spouse could specialize in domestic labor but suggests that wives are more likely to do so. See POSNER, ECONOMIC, supra note 16, at 157 (contending that wives should be the homemakers because sex discrimination in the workplace depresses women's wages and women's cost of household production is less). 
Third, PSAs should appeal to legal economists because PSAs have the potential to deter primary wage-earner opportunism. ${ }^{225}$ If the marriage contract included a PSA, then, upon divorce, the primary wage earner would have to pay an exit price by paying off the debt secured by the marital security interest. As a result, primary wage earners would exit marriages only when the cost of exit was smaller than the benefits. In this way, PSAs could discourage inefficient divorce by serving the economic function of imposing damages, restitution, or severance pay. ${ }^{226}$

Fourth and finally, PSAs would appeal to legal economists by encouraging marital-sharing behavior. Ellman's theory of alimony suggests that divorce law should encourage spouses to engage in behavior that enhances the net income of the marital unit and facilitates parental childcare, even if it involves one spouse's sacrifice of individual human capital. ${ }^{227}$ PSAs encourage marital-sharing behavior by remunerating the financially rational sacrifices and child care priorities, thus satisfying much of what many legal economists seek to achieve through post-divorce income sharing.

Because legal economists have good reason to support PSAs, and because law and economics is often associated with conservatism, ${ }^{228}$ progressive theorists might shrink from supporting PSAs. However, feminist and other contemporary legal economists embrace more progressive and diverse goals than those of the Chicago School. ${ }^{229}$ Even to the extent that legal economic and feminist analyses are incompatible, various strands of feminist legal thought also should appreciate much that PSAs have to offer.

225. PSAs could, paradoxically, create incentives for homemakers to behave opportunistically. See Joan M. Krauskopf, Comments on Income Sharing: Redefining the Family in Terms of Community, 31 Hous. L. REV. 417, 422-23 (1994) [hereinafter Krauskopf, Comments] (commenting on Carbone, Income, supra note 26).

226. See POSNER, ECONOMIC, supra note 16, at 164; Landes, supra note 26, at 62 (noting that alimony compensates wives for their opportunity costs of entering marriage and also compensates satisfied partners for the loss in the expected gain from marriage).

227. See supra note 212 and accompanying text.

228. See Minda, supra note 35, at 604-05. For a feminist critique of Posner's application of economic theory to intimate relations, see Jane E. Larson, The New Home Economics, 10 CONSTITUTIONAL COMMENT 443, 444 (1993) (reviewing POSNER, SEX, supra note 63).

229. See Minda, supra note 35, at 606. A number of feminists find economic methodology helpful, see, e.g., Brinig \& Carbone, Reliance, supra note 26, at 856 (using the reliance interest as a model for alimony); Brinig \& Crafton, supra note 196, at 871 (arguing that "the terms of the marriage contract are . . the expectations of the parties as to the allowable parameters of marital behavior"); Carbone, Income, supra note 26, at 372-92 (using economic theory to scrutinize various income sharing proposals); Carbone \& Brinig, Rethinking, supra note 26, at 955-56 (arguing that "the financial consequences of divorce" should be tied to "the performance of relatively traditional roles"), or at least not a lost cause. See Estin, Efficient, supra note 26, at 13-15 (examining the divergence in goals and analysis between feminists and traditionalist economists given their common policy goals); Estin, Problem, supra note 26, at 519 (worrying that the economics approach narrowly views marital interests as property rights); Silbaugh, Commodification, supra note 171, at 82 (urging the feasibility of legal economic tools to influence the discourse on commodifying homemaking labor); Singer, Alimony, supra note 4, at 2434-37 (using an economic rationale to justify alimony). 


\section{B. Liberal Feminist Approaches}

The various feminist approaches can be described as falling into three categories: liberal, cultural, and radical. While these camps overlap and any description of such varied groups is inevitably reductionist, this Article indulges the fiction of mutual exclusivity to explore how each strand of feminism might respond to PSAs. ${ }^{230}$ The inevitable lack of depth in this overview should be balanced by the breadth of the exploration, as its main purpose is to conduct an initial survey of how a wide range of feminists might respond to PSAs. As discussed below, PSAs offer something to proponents of each strand of feminism. In short, one size may well fit all.

1. Liberal Feminist Analysis of Marriage and Alimony.--Herma Hill Kay is among the prominent proponents of liberal feminist approaches to the problems of displaced homemakers and the devaluation of female labor generally. ${ }^{231}$ Liberal feminists, sometimes called formal equality or sameness feminists, contend that gender equality is best served when the law does not encourage traditional gender roles, such as female economic dependence. ${ }^{232}$ In the divorce law context, for example, strong alimony

230. Analyzing PSAs under various strands of feminist theory is in no way intended to suggest that one school or another is somehow superior or inferior to the others. Rather than participate in gender wars among women, this Article invokes strands of feminist thought in order to identify common ground among various approaches.

231. See, e.g., Kay, Appraisal, supra note 26, at 313 ("It would be a step backward now to propose that the wife, by her investment in the husband's education, should acquire a literal property right in his future labor."); Kay, Equality, supra note 26, at 80 (arguing that women should not be encouraged to make economically disabling choices in marriage that would perpetuate traditional financial dependence on men); see also Perry, Alimony, supra note 13, at 2519 ("A feminist theory of alimony must address the economic and psychological dependency of women on men and must confront, head-on, the implications of patriarchy."); J. Thomas Oldham, Putting Asunder in the 1990s, 80 CAL. L. REV. 1091, 1102-03 (1992) (reviewing STEPHEN D. SUGARMAN \& HERMA Hill KAY, DIVORCE REFORM AT THE CROSSROADS (1990)) [hereinafter Oldman, Asunder] ("I do not believe that family law should create incentives within families that encourage women to leave the workforce.... Instead of encouraging women to choose a path that leads to economic dependence, the law should encourage precisely the opposite."). Barbara Stark advocates for the elimination of enhanced earning capacity judgments:

because they are fundamentally unfair, not only to the spouse whose earning capacity has been enhanced during the marriage, but also to the spouse who has been encouraged by such awards to settle for vicarious achievement. Such awards are unfair because they tend to perpetuate or exacerbate the impact of the existing division of labor, thus curtailing the autonomy of both parties.

Barbara Stark, Burning Down the House: Toward a Theory of More Equitable Distribution, 40 RUTGERS L. REV. '1173, 1207 (1988). Jane Schacter has voiced this concern in her comment to my essay exploring PSAs' relevance to queer legal theory. See Jane S. Schacter, Taking the Intersexional Imperative Seriously: Sexual Orientation and Marriage Reform, 75 DENV. U. L. REV. (forthcoming 1998) (commenting on Martha E. Ertman, Reconstructing Marriage: An InterSEXional Approach, 75 DENV. U. L. REV. (forthcoming 1998) [hereinafter Ertman, Reconstructing]).

232. See, e.g., Carbone \& Brinig, Rethinking, supra note 26, at 993 (analyzing the argument that women will achieve substantive equality only with financial independence). 
provisions would encourage women to be economically dependent upon men. ${ }^{233}$ Liberal feminism justifies this formal equality approach on the ground that protecting women who make traditional choices perpetuates traditional gender roles by creating incentives to play those roles. ${ }^{234}$ While Kay has since modified her position, supporting post-divorce income sharing to compensate for one spouse's sacrifices that benefit the family, ${ }^{235}$ liberal feminist concerns about alimony continue to raise important issues for many feminists. ${ }^{236}$ Given the above discussion about how PSAs could encourage gendered specialization of labor, ${ }^{237}$ it might be hard to see how a liberal feminist could tolerate, let alone embrace, PSAs. Nevertheless, many liberal feminists might find something to appreciate in them.

2. Liberal Feminist Support for Premarital Security Agreements.-The mantra of liberal feminism is that equal participation in the wage labor force will generate equality between women and men. ${ }^{238}$ Accordingly, women's market participation will lead men to become more involved in childcare, which could, in turn, contribute to long-term redefinition of gender roles. ${ }^{239}$ One major reason why liberal feminists should like PSAs is that they are gender neutral. Either men or women could be primary homemakers or primary wage earners. PSAs only strive to financially protect the primary homemaker (of whatever sex) by recognizing her or his entitlement to a percentage of the primary wage-earner's income. This reimbursement might mean, as argued above, that PSAs would accommodate traditional gender roles. However, PSAs could just as easily encourage men to increase their participation in domestic labor as they could encourage women to specialize in it.

Liberal feminist scholars believe in the cultural malleability of homemaking and wage-earning roles, and they tend to disagree with Becker and Cohen's sociobiological analysis that women are biologically destined to care for home and hearth. ${ }^{240}$ They have reason to support PSAs

233. See Kay, Equality, supra note 26 , at 80.

234. See id. at 89-90; Perry, Alimony, supra note 13, at 2506-07; Stark, supra note 231, at 120708; cf. Oldham, Asunder, supra note 231, at 1102 (noting that encouraging women to leave work leads to "role division" that affects women's feelings of self worth).

235. See Kay, No-Fault, supra note 19, at 34.

236. See, e.g., Perry, Alimony, supra note 13, at 2506-07 (discussing the patriarchal connection between alimony and financial dependency).

237. See supra section IV(A)(2).

238. See Kay, Equality, supra note 26, at 85 ("Women, like men, should be able to lead productive, independent lives outside the family. Female dependency should no longer be the necessary result of motherhood.").

239. See id. at 82 (citing NANCY CHODOROW, THE REPRODUCTION OF MOTHERING: PSYCHOANALYSIS AND THE SOCIOLOGY OF GENDER 205-09 (1978)).

240. See Williams, Deconstructing, supra note 32, at 838 (describing liberal feminists' objection not to gender, but to the "traditional correlation between sex and gender"). 
because PSAs are just as likely to facilitate significant change in homemaking and wage-earning roles in marriage as they are to perpetuate traditional gender roles. ${ }^{241}$ Specifically, commodification of homemaking through PSAs might result in competition between men and women to play caretaking roles. At the very least, PSAs would commodify the domestic work currently done gratis by many women so that it would become wage labor. In other words, PSAs would convert domestic work into market work, which should appeal to liberal feminists who advocate women's market labor. Finally, PSAs could create an incentive for men to dissuade women from embracing traditional roles in order to relieve themselves of the security interest encumbering their income. Thus, PSAs may well further the liberal feminist goal of encouraging both men and women to divide their labor between the home and the market. ${ }^{242}$

In sum, PSAs could convert domestic labor into wage labor, create a competitive market for such labor by remunerating it, or induce men to shoulder more domestic tasks and encourage their female mates to engage in market labor. Moreover, PSAs could protect either men or women, depending on which spouse has a lower income because of his or her focus on primary homemaking activity. Thus, the rule itself is formally equal. All of these consequences cohere with much of a liberal feminist agenda.

\section{Cultural Feminist Approaches}

1. Cultural Feminist Analysis of Marriage and Alimony.-Because the tensions between liberal and cultural feminist approaches are as old as American feminism, ${ }^{243}$ it is surprising that one justification for alimony

241. While this reasoning may leave some liberal feminists cold, others may view a $50 \%$ chance of facilitating change in gender and sex roles as worth the risk, given the seemingly intractable problems of the gendered wage gap and continued delegation of most homemaking labor to women. $C f$. CENSUS, INCOME, supra note 6 , at 26-27 tbl.7 (illustrating the significant gender wage gap in the United States); HoCHSCHILD, supra note 6, at 8 (noting that women constitute the overwhelming majority of the homemaking labor force).

242. See Kay, Equality, supra note 26, at 87 . Kay contends:

[O]ur failure as a nation to develop an adequate policy that permits women both to work and to care for their children has forced many women to give up their own advancement to meet what they see as the essential needs of their children. If fathers join mothers in giving high priority to spending time with their children, they will face the same structural constraints on their job and career development that presently hinder women.

Id. (citations omitted).

243. Eleanor Roosevelt, for example, initially opposed the Equal Rights Amendment ("ERA") because she thought it would invalidate protective legislation for female workers. Alice Paul and other National Women's Party champions of the ERA, however, firmly believed that women would not enjoy equality with men until both were governed by the same rules. See BLANCHE WISEN COOK, 1 ELEANOR ROOSEVELT 354-60 (1992); see also Siegel, Home, supra note 5, at 1154-56. However, just as some economic analysts are feminists, there is no hermetic seal between liberal, cultural, and radical feminism. This Article attempts to tease out the cultural feminist strands of various scholars' work, a process that, to some extent, is inevitably reductionist. To the extent that this process reveals 
could satisfy both. Cultural feminism, also called difference feminism or substantive equality, generally contends that subjecting women and men to the same legal rules often disadvantages women because the rules are crafted to serve men and the sexes are not similarly positioned in all situations. ${ }^{244}$ Liberal feminism criticizes difference feminism for accepting the status quo rather than creating rules facilitating new gender and sexual relations. ${ }^{245}$

In the context of family law, cultural feminist scholars seek legal recognition of the unique roles women play in families. ${ }^{246}$ More specifically, they approach the related problems of displaced homemaker indigency and devaluation of female labor by focusing on ways to value female labor. ${ }^{247}$ For example, cultural feminism might expose misconceptions that homemaking and childcare do not contribute to family wealth

common ground among the various approaches, it facilitates feminist focus on addressing material problems faced by women rather than on fighting one another. See Williams, Deconstructing, supra note 32 , at 836 .

244. See FinEMAN, IlluSiON, supra note 26 , at 11 . Fineman states:

I argue for the abdication of equality. I believe women and children will fare better under legal rules which reference their material and emotional circumstances, not grand theoretical abstractions.... [S]ociety should value and reward nurturing children, sacrifices made for others, and the future that is represented by the children who have been lost to equality.

Id.; see Williams, Coverture, supra note 6, at 2245-46 ("The image that women used to be domestic, but now are full partners in two-career marriages, is more illusion than reality." (emphasis in original)). Some commentators distinguish between cultural feminists and different voice feminists, contending that different voice feminists ground their views on Carol Gilligan's groundbreaking book In a Different Voice, which suggests that men's moral reasoning tends to turn on analytical hierarchy while women's moral reasoning tends to turn on a web of interconnected relationships. See Minda, supra note 35, at 627-28. Because of the significant overlap between cultural and different voice feminists, this Article treats them together and describes this set of positions interchangeably as cultural feminism. However, not all the scholars classified here as cultural feminists adhere to the notion that women are inherently different from men. See Williams, Deconstructing, supra note 32, at 840-41. Cultural feminist approaches also could be described as more positive while liberal feminists are normative, in that cultural feminists focus on the actual lived experiences of women and aim to propose rules that reflect this reality. Favoring rules that recognize the cultural practices that delegate homemaking to women and divest it of economic and social value does not preclude advocating for a changed understanding of market and home labor that will alter those cultural practices. For further discussion, see, for example, WILliAMS, UNBENDING, supra note 35; Williams, Coverture, supra note 6; Williams, Deconstructing, supra note 32.

245. See Perry, Alimony, supra note 13, at 2506-07, 2519 (proposing that the institution of alimony may have to be sacrificed to eliminate patriarchy and women's dependence on men).

246. See, e.g., Mary Becker, Maternal Feelings: Myth, Taboo, and Child Custody, 1 S. CAL. REV. L. \& WOMEN'S STUD. 133, 138-40 (1992) (advocating a standard of maternal deference in child custody because of women's particularly close ties to their children); Christine A. Littleton, Reconstructing Sexual Equality, 75 CAL. L. REV. 1279, 1285 (1987) (proposing a model of "equality as acceptance" that renders differences between women and men costless in order to relieve women (and "the rare man") of "the costs of culturally female behavior, such as childrearing").

247. See, e.g., Starnes, Divorce, supra note 4, at 131 (proposing an "Enhanced Earnings Model" that 'values a continuing marital enterprise by measuring the spouses' enhanced ability to generate income"). 
and then seek ways to accord social and economic value to these tasks. Once this work is commodified, then the law of property division or postdissolution income sharing could account for the homemaker's contributions to the marital enterprise. Recognizing the value of homemaking and childcare services at dissolution, according to cultural feminism, would serve the practical goal of financially protecting women and their children upon divorce and also serve the theoretical goal of commodifying women's domestic work. ${ }^{248}$

Cultural feminist scholars have proposed at least three different models for understanding marriage that justify post-divorce income sharing: (1) the primary homemaker/ideal worker dominant domestic ecology described by Joan Williams; ; ${ }^{24}$ (2) the derivative dependency of those who care for inevitably dependent children and elderly relatives, as articulated by Martha Fineman; ${ }^{250}$ and (3) the commercial partnership model of marriage

248. Commodification of family roles, however, is problematic for many feminists. See Estin, Love, supra note 26, at 1062, $1064 \mathrm{n} .321$ (discussing the opinions expressed by both commentators and courts that marriage should not be commercialized nor valued like a "business or financial venture"); Staudt, supra note 141, at 1631 (focusing on the concern expressed by other commentators that taxing housework might "impose the demeaning effects of the market upon women who would have chosen to stay out of the market"); Williams, Coverture, supra note 6, at 2275 (describing how some feminists find commercial analogies in domestic relations "jarring"). Market work, like homemaking, is a mixture of both personal and financial elements. See Silbaugh, Commodification, supra note 171, at 81-82; Williams, Coverture, supra note 6 , at 2282 . Given that homemaking has significant economic elements, and these elements often are all that is left at divorce because love and obligation are long gone, the state's job is to divide assets and liabilities (and determine any custody issues). It makes sense to divide property and debt by the highly developed regimes of asset and debt distribution provided in commercial law. A cultural feminist response to this contention might defend the symbolic value of family law. See FINEMAN, ILLUSION, supra note 26, at 12 (indicating that divorce laws which account for the interests of women and children would result in practical and symbolic restructuring of the patriarchal family).

249. See Williams, Coverture, supra note 6, at 2229 ("[T] ideal-worker husband supported by a flow of domestic services from his wife . . . that supports his ability to perform as a 'responsible' 'full-time' worker, simultaneously marginaliz[ing] her market participation by precluding her from performing as an ideal worker."). Classifying Williams's work as cultural feminist (or liberal or radical for that matter) is problematic because she so carefully positions her ideas on bridges between various approaches, and indeed proposes a new approach, which she calls reconstructive feminism, as a way to transcend the debates among feminists and get to the business of deinstitutionalizing gender. See WILlIAMS, UNBENDING, supra note 35 (manuscript at 9); Williams, Deconstructing, supra note 32 , at $837-43$. Because she focuses on reconceptualizing homemaking as valuable labor, her work can be described as cultural feminist, as that term is used in this Article. See Fineman, Masking, supra note 26, at 2205-06 (noting that "imputed income-domestic labor-is not included as income although the wage earner benefits from it"). Because her work also uses postmodern techniques of deconstruction and seeks to undermine the constructed difference in male and female practices, it is also radical and will be addressed in subpart IV(D), infra. See Fineman, Masking, supra note 26, at 2205-06 (explaining that "[t]wo interrelated meta-narratives about the American family direct current social policy and limit possible policy initiatives that would help functioning, nontraditional families").

250. Like Williams, Fineman's work bridges the division between cultural and radical feminism. While her theory of caregivers' derivative dependency is cultural feminist in its call for valuing the work that many women do without receiving respect, appreciation, or remuneration, her proposed 
forwarded by Jana Singer and Cynthia Starnes. ${ }^{251}$ While these three approaches differ in important respects, they all translate women's homemaking work into financial terms or seek to redefine it to alleviate primary homemaker indigency. Because cultural feminist and legal economic approaches have dominated the literature on reinvigorating alimony, it is particularly important that PSAs cohere with these theoretical positions.

\section{a. Primary homemaker contribution to ideal worker status.-} Williams argues that primary caretakers enable their primary wage-earning spouses to become ideal workers. ${ }^{252}$ While this ideal worker/primary homemaker arrangement varies by class and race, ${ }^{253}$ the ideal worker typically is more willing to relocate for work and less willing to spend significant time on domestic chores, such as child care and homemaking, than his caregiving spouse. ${ }^{254}$ This specialization of wage labor, along with cultural patterns that show that men are more likely to be ideal workers and women are more likely to be primary homemakers, further penalizes women who do participate in the market because these factors result in higher average incomes for men than for women. ${ }^{255}$ Cultural

redefinition of family as mothers and children can only be described as radical, in the sense that term is used in this Article. Accordingly, Fineman's work is addressed in both the cultural and radical feminist parts of this Article.

251. See Singer, Alimony, supra note 4, at 2454 ("My own alternative vision of marriage would combine the equal partnership ideal . . . with the economist's recognition of enhancements in human capital as the most valuable asset produced during most marriages."); Starnes, Divorce, supra note 4, at 71 (proposing that courts treat marriages as business partnerships under partnership law). Starnes falls within the cultural feminist, rather than the legal economist, category due to a difference in focus: she articulates the damages to human identity attendant on being a displaced homemaker, while many of the economists focus only on the monetary implications of being a homemaker. See Robin West, Love, Rage and Legal Theory, 1 YALE J.L. \& FEMINISM 101, 102 (1989) ("In contrast to legal economists, cultural feminists insist that it is the capacity for trust and sense of responsibility which will facilitate a progressive and economically just legal order, rather than a relentless self-interest which necessitates a libertarian but regressive one.").

252. As discussed previously in subsection $\operatorname{III}(\mathrm{A})(2)(a)$, ideal workers are more likely than primary caretakers to work in the market full-time, year-round and devote primary attention to continuing in and up the career ladder.

253. See Perry, Alimony, supra note 13, at 2490-91, 2488-95 (“' '[S]trict sex-role segregation, with separate male and female spheres of influence within the family, has been less commonly found in African-American families than in White middle-class ones." (quoting Patricia Hill Collins, The Meaning of Motherhood in Black Culture and Black Mother-Daughter Relationships, in DOUBLE STITCH: BLACK WOMEN WRITE ABOUT MOTHERS \& DAUGHTERS 43-44 (Patricia B. Scott et al., eds. 1991))); Williams, Coverture, supra note 6, at 2239-45 (contending that class differences push lowerclass women into choosing women's work while causing high-status women, who train for traditionally male-dominated jobs, to become marginalized after childbirth).

254. See Williams, Coverture, supra note 6, at 2236-37.

255. Sex segregation in work places and sex discrimination also are relevant. See BECKER, supra note 16, at 56, 63-64; FuCHS, supra note 6, at 2, 4, 33; Cohen, Best, supra note 26, at 285. But see FuCHS, supra note 6, at 3 (suggesting that the wage differentials between men and women are due to factors other than employer prejudice). 
feminism emphasizes that despite the construction of ideal-worker status as individually earned, ideal workers are part of a domestic system that makes their status possible. ${ }^{256}$

Some women tailor their wage labor to accommodate these caregiving responsibilities and delegate many of these tasks to other, lower-status women. ${ }^{257}$ The delegates are often poor women and/or women of color, so that the problem of undervalued female domestic labor remains a pressing feminist issue even when some women pass this undervalued work on to other women. ${ }^{258}$ Moreover, the nonremuneration for labor in the home suggests that the work done by women is not sufficiently important to compensate them for it. This social attitude may translate into gendered wage differences in the labor force, ${ }^{259}$ a pattern that harms all women regardless of whether they are married to or live with men. This pervasive devaluation of female labor helps to explain why women's economic status has remained static since 1960, even though men have improved their economic well-being during the same time period. ${ }^{260}$ The asymmetry in economic status suggests that women have subsidized men's improved economic well-being, and thus provides another justification for PSAs as a method of recognizing and quantifying this subsidy.

b. Inevitable and derivative dependency.-The second cultural feminist model that justifies post-divorce income sharing is Fineman's derivative dependency theory. Fineman provocatively contends that because heterosexual couplings are sufficiently unstable, the family should be redefined to focus on mothers and children rather than on the sexual union of husband and wife. ${ }^{261}$ However, Fineman's theory also centers

256. If an ideal worker has children, for example, someone has to feed, bathe, and clean up after them, shop for their clothes, attend school events and extracurricular activities, and pick them up from school when they are sick. These tasks are prototypical women's work, even when women also participate in the paid labor force. See FuchS, supra note 6, at 72 ("Children are still predominately women's concern"); HOCHSCHLD, supra note 6, at 8-9.

257. See Roberts, supra note 43 , at 51 (arguing that "privileged women have delegated their menial household duties to other women while retaining their roles as spiritual housekeepers and mothers"); Williams, Coverture, supra note 6, at 2237 n.40.

258. See Perry, Alimony, supra note 13, at 2509 n.104 (noting the delegation of the caregiving responsibilities phenomenon); Roberts, supra note 43 , at 51 .

259. See FUCHS, supra note 6, at 122 (suggesting a correlation between the wage gap and sex-segregated employment). It is important to note that much of the wage labor market for women, particularly poor women, involves labor such as day-care, housecleaning, food service, and caring for the elderly and ill. See Roberts, supra note 43, at 60-61. Ironically, many jobs for poor women that involve domestic labor enable higher-status women to work at higher-status jobs in the wage labor force. See id. at 55-56. This pattern reveals problems embedded in any attempt to discuss in general terms the patterns of women's relationship to the wage labor force.

260. See FuCHS, supra note 6 , at 76 .

261. See FINEMAN, NEUTERED, supra note 35 , at 6 . Because this proposal is radical, it will be addressed below. 
on the cultural feminist project of recognizing and valuing traditional female labor. While other cultural feminist scholars suggest that fathers should pay for this labor by sharing their post-divorce income, Fineman suggests that the state should do so instead. ${ }^{262}$

Fineman suggests that women are more likely than men to take care of children and elderly relatives, and that this caretaking results in derivative economic dependency. ${ }^{263}$ She defends the value of these services, contending that the essential nature of caretaking, coupled with the inevitable economic vulnerability of those who need it and the derivative dependency of those who provide it, justifies state support of women in caretaking roles. ${ }^{264}$ Similarly, Ann Estin has suggested that young women need post-divorce economic support as much as older displaced homemakers, echoing Fineman's focus on women's derivative dependency due to caring for young children. ${ }^{265}$ Cultural feminist scholars recognize that, for better or for worse, women perform the lion's share of caretaking responsibilities, and they contend that the law should recognize and value these contributions rather than dismiss them as gratuitous (or, in economic terms, financially irrational choices). ${ }^{266}$

c. Division of the return on marital partnership investments.Like other cultural feminist analysts, Starnes and Singer propose models of marriage that justify post-divorce income sharing as a way to commodify primary homemakers' contributions to primary wage earners' post-divorce stream of income. However, as already mentioned, Starnes and Singer differ from others in their explicit adoption of partnership dissolution business models to solve the family law problem of devaluation of feminine contributions to marriage. ${ }^{267}$ Starnes's proposal is more elaborate than Singer's, detailing a model for divorce income sharing based on business

262. See id. at 232. Fineman also supports post-divorce income sharing and property distribution based on an increased valuation of the woman's homemaking and childcare work. Indeed, she contends that in some circumstances women should be entitled to more than half of the marital property to accommodate their post-divorce child care responsibilities and to level the otherwise unequal playing field between men and women after divorce. See FinEMAN, ILluSION, supra note 26, at 9, 175-78.

263. See FINEMAN, NEUTERED, supra note 35, at 161-62.

264. See id. at 232-33. Fineman's approach seeks to value the homemaking of women, regardless of whether they work outside of the home in addition to their primary caretaking responsibilities. See FINEMAN, ILLUSION, supra note 26, at 47 (acknowledging that many women "must work at low-paying, often unfulfilling jobs to earn money for meeting family needs and, in addition, must perform the tasks of raising children and maintaining a home").

265. See Estin, Maintenance, supra note 26, at 743-46 (arguing that the disparate treatment of older and younger wives cannot be explained on doctrinal grounds).

266. See Carbone, Reply, supra note 58, at 1481 (criticizing Ellman for considering some homemaking services economically irrational).

267. See supra note 255. 
partnership buyout rights. ${ }^{268}$ Starnes's proposal has both legal economic and cultural feminist elements: it invokes a market model and uses human capital theory to justify the homemaker's buyout share, but it also serves the cultural feminist goal of socially and legally valuing women's work in the home. ${ }^{269}$ Like other cultural feminist proposals, the partnership model of alimony is based on restitutionary notions that the primary homemaker contributes to the primary wage earner's ideal-worker status, which also results in the homemaker's economic dependency. ${ }^{270}$ The partnership buyout thus reimburses the primary homemaker for her marital investments and prevents the primary wage earner from walking away with more than his share of marital assets.

While Williams, Fineman, Starnes, and Singer differ significantly in their approaches to valuing women's work in the home, they share two cultural feminist characteristics. First, they assume that women (or those who are gendered female) likely will continue to do most of the homemaking and tailor their proposals accordingly. ${ }^{271}$ They share this presumption of the intransigence of traditional gender roles in marriage with traditionalist legal economists, who maintain that gendered labor specialization is efficient and thus support legal regimes that reward traditional roles in marriage. However, the second key element shared by the cultural feminists differs markedly from traditionalist legal economists; unlike traditionalist legal economists, cultural feminists are determined to craft proposals that undermine patriarchal family patterns. ${ }^{272}$ Because PSAs serve both of these goals, protecting women in traditional domestic roles and having the potential to undermine misogynist family organizational structures, there is good reason to think that many cultural feminists would support them.

\section{Cultural Feminist Support for Premarital Security Agreements.-} Given the wide ideological divide between cultural feminists and traditionalist legal economists, it would be counterintuitive for both camps to embrace PSAs. Indeed, several cultural feminist commentators explicitly reject commercializing marriage through partnership and other market-

268. See Starnes, Divorce, supra note 4 , at 130-37.

269. Cf. id. at 76 (explaining that the risk of post-divorce financial exposure for many women has increased).

270. This statement may not fully capture Williams's long range plan to deconstruct gender and reconstruct wage labor so that it is no longer structured to accommodate ideal workers whose status is made possible by marginalized caregivers. For further discussion, see, for example, WiLLIAMS, UNBENDING, supra note 35; Williams, Coverture, supra note 6; Williams, Deconstructing, supra note 32.

271. See supra notes $248-50$.

272. Fineman, for example, intends "to challenge the patriarchal norm of the male-defined and male-headed family with a heterosexual union at its core." FINEMAN, ILLUSION, supra note 26, at 12. 
based models. ${ }^{273}$ However, PSAs play to the similarities in legal economic and cultural feminist approaches, and downplay the tension between them. Cultural feminists should appreciate PSAs for at least four reasons: (1) they commodify the flow of domestic services that make an ideal worker's status possible; (2) they account for the derivative dependency of women who care for children and other dependents; (3) they recognize the partnership-like elements of marriage and offer a procedural tool to implement the buyout; and (4) they generate respect for homemaking on both practical and theoretical levels.

\section{a. Recognizing homemaker contributions to ideal worker status.-} First, PSAs assign monetary value to homemaker contributions to idealworker status. Williams makes a compelling argument that homemakers contribute to primary wage earners' ideal-worker status but does not provide a procedure for implementing post-divorce income equalization. ${ }^{274}$ PSAs supply this model. They additionally make explicit the creditor-debtor relationship between homemakers and wage earners to which Wiliiams hints but does not specifically identify. ${ }^{275}$ PSAs provide a concrete way to implement collection procedures on the loans primary homemakers make to their primary wage-earning spouses. The debtor-creditor model offered by PSAs strengthens Williams's argument and provides a fully developed legal doctrine regulating the creation and enforcement of homemakers' security interest in marital property.

The inadequacy of proposals that treat primary homemakers as either victims or equals emerges as a theme in discussions regarding reinvigorating alimony. ${ }^{276}$ Traditional justifications for alimony construct primary homemakers as victims, awarding alimony because a woman is deemed incapable of supporting herself with market labor, and terminating it when

273. See supra note 248 (addressing the cultural feminist distrust for commercializing family in more detail).

274. Williams proposes equalizing the standard of living in the two households and rejects either splitting income equally between the two households or allocating a percentage of income to each person in the household. See Williams, Coverture, supra note 6, at 2258 (explaining that these methods either underestimate the costs of child care or disregard the different entitlements of children and adults when one household contains the primary caregiver).

275. See id. at 2287. Williams argues:

[I] the medical student had received a loan from the bank, he would be expected to pay it back, with interest such that he ended up paying roughly three times the size of the original loan. Instead, he received a loan from the wife, who expected to be repaid by accessing human capital through her man rather than through her job, or by being supported at a later point while she built up her own human capital. . . . [S] he should be repaid by sharing her husband's professional income for the same period for which she shared hers with him.

Id.

276. See, e.g., FINEMAN, ILLUSION, supra note 26, at 46 (arguing that proposals which focus on these "polar opposites" ignore the reality that most women fall in between these stereotypes). 
she remarries (thus transferring the duty of support from the first to the second husband). ${ }^{277}$ Contemporary formulations, in contrast, award alimony only in extraordinary circumstances and construct primary caretakers as equals to primary wage earners, totally disregarding the structural differences in economic situations that result in severe hardship for caretakers upon divorce. ${ }^{278}$ Martha Fineman suggests that the "futile attempt to reconcile" these stereotypes of equality and dependency narrows our analysis; ${ }^{279}$ PSAs offer one way out of the Catch 22 in which women have the spurious choice between two unattractive alternatives.

PSAs have the potential to transcend the victim/equal dichotomy because they combine roles from both victimhood and equality. If a primary homemaker is also a secured creditor, she unites the caretaking values of domestic labor and the economic independence (indeed, dominance) values of the marketplace. She is neither victim nor equal but adopts a new role, combining the two roles in a way that erodes the dichotomy at its foundations.

b. Accommodating derivative dependency.-The second reason PSAs should appeal to cultural feminists is that they could both recognize and alleviate the derivative dependency of childrearing. ${ }^{280}$ As a practical matter, PSAs should alleviate the economic hardships of the many displaced caregivers who stand to gain from sharing in their former spouses' incomes. On a more theoretical level, they contribute to the redefinition of both family and the value of caregiving. PSAs redefine marriage as both a commercial relationship between the parties that involves one spouse making a loan to the other spouse and an entitlement to repayment of that loan. ${ }^{281}$ This commercial model is less gendered than the current one, and thus radically redefines marriage. If legal and social understandings of marriage shift from patriarchal toward commercial models, that change might soon lead to focusing on the dependency of caregivers. While income-sharing proposals are private by nature, they also have the potential to increase the social and economic value given to homemaking. Once that

277. The ALI Principles perpetuate this rule by providing for the termination of post-divorce income sharing upon either the recipient's remarriage, see ALI, PRINCIPLES, supra note 108, § 5.08, or upon cohabitation in a marriage-like relationship (same-sex or opposite-sex). See id. $\S 5.10$, at 369$70,373$.

278. See UNIF. MARRIAGE AND DIVORCE ACT § 308, at 446 (amended 1973), 9A U.L.A. 446 (1998).

279. See FINEMAN, ILLUSION, supra note 26 , at 46 (concluding that "the futile attempt to reconcile [stereotypes] tend[s] to narrow rather than expand the definition of acceptable results").

280. See supra text accompanying notes 261-66.

281. But see FINEMAN, Illusion, supra note 26, at 42 (preferring need, and to a lesser extent, fault, to compensation or entitlement as a measure of a primary homemaker's entitlement in property distribution decisions). 
happens, perhaps Congress might become less hostile toward the kind of public entitlement for caregiver compensation that Fineman supports.

c. Building on the partnership models.-Third, PSAs have much to offer the cultural feminist commentators who embrace partnership models of marriage, most obviously in the way that PSAs and partnership models share private-law business related origins. ${ }^{282}$ As imports from business to family law, PSAs and partnership models both invoke doctrines that calculate entitlement to a return on an investment. As such, they offer an alternative to the traditional conception of homemaking as work done for love rather than money. In a similar vein, PSAs should appeal to partnership theorists because the primary homemaker's security interest is an entitlement to a share of marital property rather than a charitable payment based on homemaker need. Starnes, for example, contends that the buyout should not terminate on remarriage because it is a return on investment, making remarriage irrelevant to the amount due. ${ }^{283}$

PSAs, moreover, build on partnership models by taking into account post-divorce contributions to the primary wage earner's ideal-worker status, and intervening in the gendered power imbalance in marriage. Partnership models divide assets that exist at the time of divorce, assuming that partners cease to invest in the partnership after dissolution. ${ }^{284}$ This assumption does not hold true for many marriages, however, particularly when there are children involved. In most divorces the primary caretaker has child custody, and thus, even after divorce, continues to perform services that contribute to the primary wage earner's income. ${ }^{285}$ For example, a divorced mother might tailor market participation by, for example, working part-time, or less than all of the year, in order to perform childcare tasks such as cooking, bathing, cleaning, helping with

282. PSAs differ from partnership models in several ways. For example, partnership models assume a pre-existing relationship of relative equality, and security agreements often are executed between near strangers but create long-term obligations that inform the rest of the parties' relationship. Moreover, inherent power differentials exist between creditors and debtors that are absent from the default understanding of a partnership. For example, a creditor may participate in a debtor's business decisions in order to protect its interest in collateral, and often the creditor incorporates other terms into the security agreement that entitle it to declare default and foreclose on the collateral as soon as it deems itself at risk for not being repaid. See RAYMOND T. NIMMER \& INGRID MICHAELSON HILlinger, COMMERCIAL TRANSACTIONS: SECURED FINANCING 27 (1992). However, if a creditor interferes too much with a debtor's business, the creditor might be liable for consequences of that interference. See id. at 28-32 (explaining that creditors may face equitable and tort liabilities for various types of overreaching conduct).

283. See Stames, Divorce, supra note 4, at 138 (suggesting that "[i]t would be ludicrous to contend that a commercial partner should receive a reduced buyout because she is financially secure").

284. See id. at 123 (explaining that this model "underscores the clean-break notion of no-fault divorce statutes").

285. See Williams, Coverture, supra note 6, at 2259-61. 
schoolwork and other projects, and transporting children to and from school and extracurricular activities. Even after the child reaches majority, the primary caretaker is likely to be asked for "loans" or to allow the child to reside with her. ${ }^{286}$ Because the primary caretaker performs all of these tasks (and many more), the primary wage earner remains free to maintain his full-time (or more), year-round participation in the wage labor force.

PSAs also build on partnership models by intervening in the gender inequalities of marriage in a way that partnership models do not. The appeal of partnership models is their very equality: They recognize contributions to family wealth made by both market and nonmarket labor. ${ }^{287}$ However, this egalitarianism may prevent partnership models from implementing fundamental changes in marriage. PSAs, in contrast, counteract the gendered hierarchy of marriage with the commercial hierarchy of creditor over debtor and thus have the potential to neutralize the gendered hierarchy by granting disproportionate power to primary homemakers. Say, for example, that men in marriage enjoy two units of power for every one unit that women enjoy. ${ }^{288}$ Partnerships allocate power equally between the parties by adding one unit of power to each spouse, so that a partnership model superimposed on marriage would leave men with three units of power and women with only two units. Partnership thus fails to intervene in pre-existing gendered power differentials in marriage. PSAs, however, might allocate power differently. Under a PSA, the secured creditor/homemaker has two units of power for every one unit of power enjoyed by the debtor/primary wage earner. Therefore, superimposing the PSA onto pre-existing gendered power differentials in marriage results in both spouses enjoying three units of power. PSAs intervene in gendered power structures of marriage only because they, like marriage, are hierarchical. By giving primary homemakers the powerful role that secured creditors enjoy in the marketplace (and making primary wage earners debtors), PSAs have the potential to balance the hierarchy of marriage.

Finally, even if partnership model theorists reject PSAs, PSAs could provide a procedure for implementing the primary homemaker's entitlement to a buyout of the marital partnership. ${ }^{289}$ For these reasons feminist

286. See FINEMAN, ILLUSION, supra note 26 , at 44 (suggesting that children's continued economic dependence, in turn, extends women's economic dependency).

287. See Starnes, Divorce, supra note 4, at 110 (suggesting that an expanded restitution model of protecting contractual interests accounts for nonmarket contributions associated with caretaking in divorce settlements).

288. See Krauskopf, Recompense, supra note 26, at 399 (discussing how factors such as education differentials play out as future-eaming power differentials in marriage); see also CENSUS, INCOME, supra note 6, at 26-27 tbl.7 (documenting higher median incomes for men than women).

289. See infra Part VI. 
commentators who support partnership models as justifying post-divorce income sharing should also support PSAs.

d. Generating respect for homemaking.-Fourth and finally, PSAs should appeal to many cultural feminist scholars because PSAs have the potential to change the social meaning of homemaking and femininity. PSAs do this in both practical and symbolic ways.

(1) Practical effects.-As a practical matter, PSAs justify more post-divorce income sharing than currently occurs. Alimony is awarded in only about fifteen percent of divorces. ${ }^{290}$ Certainly more than fifteen percent of marriages conform to the dominant family ecology. ${ }^{291}$ If states enacted PSAs, primary homemakers (many of whom would not receive alimony under the current doctrine $)^{292}$ would receive annual payments equal to thirty percent of the difference between their income and their primary wage-earning spouse's income as reimbursement for their continuing childcare and other domestic efforts. Moreover, these primary homemakers would enjoy self-help remedies which obviate the need for expensive attorney involvement.

PSAs also offer a practical solution to some of the economic problems faced by low-income women. To the extent that PSAs are a means of justifying and implementing post-divorce income sharing, they do little for a homemaker whose spouse has insufficient income to be garnished. In these situations, PSAs could be treated as marital debt assessed against the nonhomemaking spouse. Thus, as a practical matter, PSAs could diminish the marital debt allocated to primary homemakers, which would be particularly welcomed by those spouses whose continued homemaking efforts hamper their ability to shoulder an equal share of marital debt at dissolution. In sum, PSAs have practical benefits for a wide variety of displaced homemakers.

(2) Theoretical effects. - In addition to protecting typical women, cultural feminism also aims to change social understandings of gender in order to increase the valuation of female labor. ${ }^{293}$ PSAs have the

290. See Singer, Divorce, supra note 26 , at $1106-07$ (reporting an alimony rate of $16.5 \%$ in California after the adoption of no-fault divorce); Sugarman, supra note 26, at 133; Marigold S. Melli, Alimony Trends: Which Way the Wind Blows Has an Impact on How You Handle These Cases, FAM. ADVOC., Fall 1996, at 21, 22 (reporting the alimony rate in the late nineteenth century at $9.3 \%$, and contemporary rates of $14.3 \%$ in 1978 , and $15 \%$ in 1990).

291. See FUCHS, supra note 6, at 4.

292. See UNIF. MARRIAGE AND DIVORCE ACT § 308, at 446 (amended 1973), 9A U.L.A. 446 (1998) (providing for an award of spousal maintenance only when the spouse seeking maintenance cannot provide for himself).

293. See Marion G. Crain, Feminizing Unions: Challenging the Gendered Structure of Wage Labor, 89 MiCH. L. REV. 1155, 1187-88 (1991). 
potential to effect this powerful symbolic change. PSAs designate primary homemakers and wage-earning spouses as creditors and debtors in relation to each other. Attributing creditor status to a homemaker has tremendous impact on the social meaning of domestic work by associating it with entitlement, economic and social power, and the benef icial role of facilitating economic relations in the greater society. Cultural feminists should appreciate these theoretical effects because they further the cultural feminist goal of valuing everyday homemaking labor, rather than asking women to act like men as a precondition to economically (and socially) valuing their work.

In sum, cultural feminist scholars might have good reason to support PSAs because PSAs recognize and remunerate primary homemaker contributions to ideal-worker status, address the dependency of caregivers, and build on partnership models justifying post-divorce income sharing. Cultural feminist and traditionalist legal economic support for PSAs is particularly important because these ideological approaches have dominated the discussion about reinvigorating alimony. While cultural feminist and traditionalist legal economic approaches share a respect for the status quo of gender relations, they differ considerably in their understanding of the causes of this status quo and whether it is normatively appealing. ${ }^{294}$ If PSAs can serve both normative ends-supporting patriarchy as efficient or eroding it as oppressive-then they can serve the goals of both traditionalist legal economics and cultural feminism.

It is hard to see how PSAs could also encompass the interests of radical feminists who reject both the economic goal of efficiency and the cultural feminist goal of valuing traditional femininity. However, even radical feminism, with its focus on completely redefining our understanding of gender by undermining binary understandings of sex and gender, may find something to appreciate in PSAs.

\section{Radical Feminist Approaches}

Radical feminism is the third and final strand of feminist analysis addressed in this Article. The term radical embraces a wide variety of feminist approaches; its present incarnation could be described as radically redefining sex and gender to destabilize the hierarchy of men over women. ${ }^{295}$ Because liberal feminism contends that women will cease to

294. See e.g., Cohen, Rhetoric, supra note 53, at 2290, 2284-94 (expressing hostility toward Fineman's article, Masking Dependency, supra note 26 , and defending traditional marriage as "marvelous").

295. Radical feminism could be described as whatever discourse markedly changes the way we think about gender. Catharine MacKinnon was associated with radical feminism in the 1980s, but poststructural feminists such as Judith Butler are more closely associated with radical feminism in the 1990s. Perhaps the radical feminists in the nineteenth century were the ones who most pushed the boundaries of contemporary understandings of women's entitlements to wealth through family labor or 
be subordinated to men when they enjoy equal treatment, and cultural feminism argues that equality is a rigged game most women are predestined to lose, the former focuses on male entitlements and the latter on female experiences. A radical feminist analysis rejects these polar preferences, instead asking what would happen if we did not have to choose between being men and being women because gender (masculine/feminine) and sex (male/female) were no longer constructed as a dyad of complementary opposites. ${ }^{296}$

A radical feminist approach to the alimony problem might suggest revising legal treatment of the homemaker/ideal wage-earner dichotomy, perhaps inverting it, perhaps parodying each role. The radical feminist analysis would aim to undermine the current duality of femininity and masculinity by creating something else, perhaps a hybrid of the two extremes. In short, a radical feminist approach to alimony would subvert the hierarchy of men over women by blurring the boundaries between their roles.

As discussed above, elements of Williams and Fineman's work propose a radical restructuring of the family and workplace (and thus of gender). ${ }^{297}$ Before describing these radical elements and suggesting how they might cohere with PSAs, a brief review of Judith Butler's formidable analysis of the social construction of gender is useful.

1. Radical Feminist Analysis of Marriage and Alimony.-A radical feminist analysis of marriage seeks to undermine the legal regulations that make marriage the only or best option for women. ${ }^{298}$ Because PSAs depend on the dominant domestic ecology in which women marry men, a radical feminist scholar might initially reject PSAs as engines of compulsory heterosexuality. ${ }^{299}$

market labor. For a discussion of various stages of nineteenth century feminist activism regarding the value of women's work in the home, see generally Siegel, Home, supra note 5.

296. See BUTLER, GENDER, supra note 35, at 6-7 (explaining the radical split between gender and sex as permitting multiple gender roles and interchangeable gender labels that may be applied to either sex).

297. See supra notes 249-50.

298. See, e.g., Adrienne Rich, Compulsory Heterosexuality and Lesbian Existence, in THE LESBIAN AND GAY STUDIES READER 227, 233-34 (Henry Abelove et al. eds., 1993) (hereinafter Rich, Compulsory] (describing eight characteristics of male power, many of which are associated with marriage, including: "child marriage; arranged marriage . . . marriage and motherhood as unpaid production; . . . genital mutilation or [foot binding] to fit [women] for marriage[;] . . prescriptions for 'full-time' mothering at home; enforced economic dependence of wives[;] . . . [and] restriction of female self-fulfillment to marriage and motherhood" (emphasis added)).

299. See id. at 232 (" $[\mathrm{H}]$ eterosexuality, like motherhood, needs to be recognized and studied as a political institution." (emphasis in original)). Rich also notes that "[t]he lie of compulsory female heterosexuality ... creates, specifically, a profound falseness, hypocrisy, and hysteria in the heterosexual dialogue, for every heterosexual relationship is lived in the queasy strobe light of that lie." 
Compulsory heterosexuality depends on an understanding that men and women are fundamentally different and complementary; Butler counters this premise by arguing that gender is neither fixed nor natural, but rather performative, a collection of acts representing a mythical ideal. ${ }^{300}$ With the important qualifications that not all gender parodies subversively serve a feminist agenda, ${ }^{301}$ and that one does not freely choose a gender each day in the way one chooses a sweater or jacket, ${ }^{302}$ Butler offers a recipe for women to exercise some measure of control over the continual construction of gender identity.

Within the dominant family ecology, ${ }^{303}$ the primary wage earner is gendered male and the primary homemaker is gendered female. Traditionalist legal economists contend that these roles are based on sex, so that women's ability to gestate determines their role as primary caretakers of home, hearth, and heirs. ${ }^{304}$ Butler would contest this explanation of gender roles, suggesting instead that the very designation of sex, let alone gender, as natural is a cultural artifact that serves to obscure the fact that sex and gender are culturally created. ${ }^{305}$

Id. at 244. Judith Butler substitutes the phrase "heterosexual imperative" for compulsory heterosexuality. BUTLER, BODIES, supra note 35 , at 2 . Either approach requires that feminists carefully interrogate proposals which support or compel marriage (or heterosexuality for that matter) to see if they limit women's potential by pigeonholing them into traditional gender roles. Adrienne Rich's groundbreaking essay, Compulsory Heterosexuality and Lesbian Existence, see supra note 298, at 227, articulates this compelling radical feminist skepticism toward marriage, and Judith Butler, see BUTLER, GENDER, supra note 35 , at 2, expands Rich's analysis by interrogating compulsory heterosexuality using post-structural theory.

300. See BUTLER, GENDER, supra note 35 , at 25 . Butler maintains:

[G]ender proves to be performative-that is, constituting the identity it is purported to be. In this sense, gender is always a doing, though not a doing by a subject who might be said to preexist the deed. ... There is no gender identity behind the expressions of gender; that identity is performatively constituted by the very "expressions" that are said to be its results.

Id.

301. See id. at 139 ("Parody itself is not subversive.").

302. See BUTLER, BODIES, supra note 35 , at $\mathrm{x}$.

303. See Williams, Coverture, supra note 6, at 2229.

304. See supra subsection $\operatorname{IV}(\mathrm{A})(1)(\mathrm{b})$. Under this reasoning, men's natural drive to maximize their gene pool destines them to market labor (or, in preindustrial cultures, to hunt for animals), while women's natural instinct to protect their young leads them to specialize in childcare and other domestic tasks. Richard Posner is a recent proponent of this reasoning in legal scholarship. See POSNER, SEX, supra note 61, at 89-91 (arguing that biological sex differences facilitate task specification and social roles defined by gender). Posner further accepts sociobiological arguments that men are naturally promiscuous to maximize the chance that their genes will be replicated in a maximum number of offspring, so that a maximum number, in turn, will survive to adulthood in order to continue the man's gene line. Id. at 90-95 (discussing promiscuity and natural selection). The picture painted thus shows men hunting both women and animals, toward the ultimate end of accomplishing a conquest over other men for control over the gene pool. See Martha Ertman, Denying the Secret of Joy: A Critique of Posner's Theory of Sexuality, 45 STAN. L. REV. 1485, 1493-97 (1993).

305. For Butler, gender and sex are both socially constructed, and nothing is real, prediscursive, or inevitable. See BUTLER, GENDER, supra note 35, at 7. Gender Trouble focuses on the malleability of gender, explaining that performativity reveals the lack of an essential gender identity: 
Butler illustrates her theory of gender performativity by describing how drag shows demonstrate that gender is a social construction, a performance. When a male drag queen impersonates or parodies an idealized femininity, the performance itself suggests that in less explicitly dramatic contexts women and men perform their gender. Thus, gender is shown to be a cultural artifact, not a natural extension of biological sex. The theory's subversive potential lies in its flexibility: even conduct that seems to support the status quo might, in fact, undermine existing power relationships, at least in part. ${ }^{306}$

These subversions, understood as gender performativity, offer an opportunity to reshape sex, gender, and sexual orientation. ${ }^{307}$ Perhaps the homemaker, like the drag queen, plays a role that similarly has the potential to reshape gender. Unlike the drag queen, of course, the homemaker does not perform for money or entertainment, and her costume and performance are probably drab in comparison to the drag queen's. However, drag queen and homemaker are both representations of idealized femininity. As such, radical feminists should appreciate a homemaker's potentially subversive performance of femininity as much as a drag queen's. ${ }^{308}$

Few have plumbed the radical feminist potential of alimony, perhaps because valuing women's traditional domestic work seems inconsistent with radical feminist visions of intimate relations far different than the dominant domestic ecology. ${ }^{309}$ As discussed below, PSAs are consistent with the

If gender attributes and acts . . . are performative, then there is no preexisting identity by which an act or attribute might be measured; there would be no true or false, real or distorted acts of gender, and the postulation of a true gender identity would be revealed as a regulatory fiction.

Id. at 141.

306. Butler's description of the subversive potential of butch-femme roles in lesbian culture illustrates this point. She contends that butch-femme identities do not imitate heterosexual coupling, but rather challenge the naturalness of heterosexual roles. In other words, a butch lesbian crafting her own version of masculinity challenges the notion that gender flows from sex (i.e., women are feminine and men are masculine), and in doing so destabilizes the categories woman and masculine. Id. at 123.

307. See id. at 124 (stating that "parodic contest . . . robs compulsory heterosexuality of its claims to naturalness and originality").

308. Butler's theory of gender performativity and queer theory generally have been criticized for positing women, feminists, and lesbians as repressive or boring "Others." See Suzanna Danuta Walters, From Here to Queer: Radical Feminism, Postmodernism, and the Lesbian Menace (Or, Why Can't a Woman Be More Like a Fag?), 21 SIGNS 830, 830 (1996). If poststructural feminist theory accepts the subversive potential of men impersonating women, it logically should apply to women impersonating women (or men), as well. If not, queer theory unintentionally supports the very sexism and homophobia it purports to oppose by "eras[ing] lesbian specificity and the enormous difference that gender makes." Id. at 843.

309. See Williams, UNBENDING, supra note 35 (manuscript at 24) (suggesting that feminists "approach domesticity as Butler approaches feminine gender performance, not with a peremptory demand for its immediate abandonment, but with the goal of focusing attention on the contingent and stitched-together quality of our performances. Suppleness and a sense of open-ended play are important 
key tenets of radical feminism: (1) they reveal the social construction of gender; (2) they destabilize constructions of female homemaking as natural; and (3) they destabilize gender by attributing the powerful market role of a secured creditor to the relatively weak role of primary homemaker. In Butler's terms, PSAs have the potential to make gender trouble. ${ }^{310}$

2. Radical Feminist Support for Premarital Security Agreements.Radical feminists should appreciate PSAs' ability to reveal the social construction of gender roles in marriage. PSAs undertake the "critical task" for radical feminism "to locate strategies of subversive repetition enabled by those [constructed identities], to affirm the local possibilities of intervention through participating in precisely those practices of repetition that constitute identity and, therefore, present the imminent possibility of contesting them." ${ }^{111}$ In other words, radical feminists identify opportunities for subversive repetition of identity constructions, repeat those identity constructions, and in doing so reveal their status as socially constructed rather than natural. Under PSAs, the relevant identity is that of a married woman in a traditionally female gender role as primary homemaker. The repetition is her continued performance of that role, but with the twist of commodifying her domestic labors through a PSA. By playing the feminine domestic role with the (masculine) market accoutrements of a secured creditor, the homemaker reveals that her role is constructed rather than natural. Like a drag queen, she "juxtapos[es] gender norms and gender deviance to destabilize the whole structure." 312 By simultaneously playing the traditionally female (domestic) and the traditionally male (market) roles, the primary homemaker/creditor thus destabilizes two hierarchical dichotomies: male/female and market/family.

weapons if the goal is domesticity as drag."). A Comment applies Butler's gender performativity theory to divorce reform, rejecting liberal and cultural feminist approaches because they "reify contemporary notions of masculinity and femininity." Comment, Patriarchy, supra note 35, at 2003

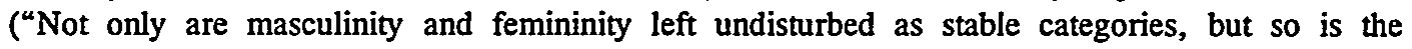
market/family distinction that makes gender roles seem natural rather than social."). Asserting that "the best proposals will make gender trouble," the authors suggest:

feminist strategies for addressing women's economic distress upon divorce should denaturalize gender and thereby make manifest that no answers follow from mere maleness or femaleness, but only from the values we bring to the debate. . . . A good proposal will deploy gender categories much as the drag queen does, juxtaposing gender norms and gender deviance to destabilize the whole structure.

Id. at 2004. The Comment further finds market metaphors (such as contract and partnership theories of marriage and divorce) useful because they emphasize economic aspects of marriage, and also destabilize the market/family dichotomy. Id. at 2005. Using market metaphors is "strategically promising," according to the authors, revealing marriage as at least partly an economic exchange, and "denaturaliz[ing] marriage by uncovering its roots in deeply market-oriented concerns." Id.

310. See BUTLER, GENDER, supra note 35.

311. Id. at 147.

312. Comment, Patriarchy, supra note 35, at 2004. 
In doing so, she serves two radical feminist ends. First, she contributes to a radical redefinition of masculinity and femininity. Second, by undermining the distinction between market and family which is central to the masculine/feminine dichotomy, she demonstrates that there is nothing essentially natural, prediscursive, or inevitable about either role.

In addition to revealing the constructed nature of domestic femininity, PSAs could create incentives for men to behave in ways that might appeal to radical feminists. As previously discussed, more men might engage in primary homemaking activities if homemaking came with the security and status of a PSA. ${ }^{313}$ Furthermore, radical feminists might endorse PSAs if the latter contribute to the erosion of gender hierarchy by reshaping the terms of the marriage contract that assign household tasks disproportionately to wives and simultaneously devalue them. ${ }^{314}$ Marriage continues to retain much of the patriarchal influence that it has historically symbolized: ${ }^{315}$ many married women do not participate in the wage labor force, marriage increases men's market potential while decreasing women's, and women do the majority of housework even when they work outside the home. ${ }^{316}$ If PSAs made men more likely to be primary homemakers, then they could significantly advance the radical feminist goal of changing the related hierarchies of men over women and the market over the family.

313. See supra section IV(B)(2).

314. While this Article defines radical feminism within the context of recent theoretical developments in postmodem feminism, 1980s radical feminism, grounded in Catharine MacKinnon's dominance approach to gender inequality, would also be served by the way that PSAs redistribute powerful market tools to primary homemakers. This dominance approach has been described as typical of radical feminist approaches to legal scholarship. See Minda, supra note 35, at 628-29 (describing MacKinnon as "see[ing] gender hierarchy and sexual domination in legal and social relations . . . that are taken as unobjectionable, natural, and even as 'intrinsic' to traditional gender roles"); see also MACKINNON, FEMINIST THEORY, supra note 8, at 80 (calling for wages for housework to counteract the minimization of the value of women's work and the subsequent exclusion from socially powerful activity).

315. These inequalities in marriage are deeply rooted. Claude Levi-Strauss described marriage as the exchange of women, a process in which women are gifts men give to one another to solidify male-male alliances. See Gail Rubin, The Traffic in Women: Notes on the Political Economy of Sex, in TOWARD AN ANTHROPOLOGY OF WOMEN 157, 173 (Rayna R. Reiter ed., 1975) ("[M]arriages are a most basic form of gift exchange[,] in which it is women who are the most precious of gifts."). Under this analysis of marriage rituals, women are conduits to relationships between men, rather than participants in the transaction, oijects rather than subjects. Id. at 174 ("If it is women who are being transacted, then it is the men who give and take them who are linked, the woman being a conduit of a relationship rather than a partner to it."). While Levi-Strauss builds his argument that all kinship is based on men exchanging women from data gathered on nonindustrial societies, remnants of the exchange model persist in contemporary America. See infra note 319.

316. See FUCHS, supra note 6, at 72-73; HocHSCHILD, supra note 6, at 7-8; Williams, Coverture, supra note 6, at 2245 ("[M]arriage enhances men's market potential, while eroding women's: married men make more than single men, whereas married women earn less than single women."). 
The PSAs' focus on marriage may repel many radical feminists who target marriage as the key to women's subordination to men. ${ }^{317}$ Despite legal and social formal equality rhetoric, they argue, artifacts of women's subordination in marriage persist. ${ }^{318}$ For example, fathers typically give away their daughters in weddings, many women take their husbands' names, and most children have their fathers' last name. ${ }^{319}$ Additionally, radical feminist analysis would likely suggest that the hierarchy of men over women in marriage is a key factor contributing to nonremuneration of female domestic labor in their homes, lower wages for women in the market, and domestic violence. ${ }^{320}$ For these reasons, radical feminists see marriage as central to a misogynist regime in which women and children are systematically subordinated to men. ${ }^{321}$ Rather than supporting these oppressive aspects of marriage, PSAs could address them by remunerating primary homemakers' work in the home by making them creditors in relation to their primary wage-earning spouses. An additional bonus for radical feminists is that making primary homemakers secured creditors also has symbolic significance.

Secured creditors are among the most powerful legal players in American law. They can repossess debtors' property, including cars,

317. See, e.g., Rich, Compulsory, supra note 298, at 233 (citing the institution of marriage as characteristic of the power of men tc command or exploit the labor of women as unpaid production).

318. See Siegel, Protection, supra note 5, at 1113 (describing the process whereby legal and social hierarchies are maintained through a process she dubs "preservation-through-transformation"); Williams, Coverture, supra note 6, at 2281 (asserting that the disparity in market power between husbands and wives gives husbands a dominant role in the marriage).

319. See Rubin, supra note 315 , at 176 (referring to "the curious custom by which a father gives away the bride"); see also BUTLER, GENDER, supra note 35, at 74 (referring to Rubin's call for a "revolution in kinship" as a way to eradicate "the exchange of women, the traces of which are evident not only in the contemporary institution of heterosexuality, but in the residual psychic norms . . . which sanction and construct sexuality and gender identity in heterosexual terms"). A recent newspaper article articulates puzzlement about the simultaneous presence of equality and tradition in marriage:

Weddings have shown themselves to be very resistant to change in a country eagerly promoting gender equality and informality. The ceremony continues to cast the bride in anachronistic, if not demeaning roles: unapproachable princess in a spectacular, impractical gown. Sacrificial virgin in white. Currency handed off from the old patriarch to a budding one.

Constance C.R. White, The Price a Woman Pays to Say 'I Do,' N.Y. TIMES, June 29, 1997, at E5.

320. See Comment, Patriarchy, supra note 35, at 1994-95 ("Women's full participation in the labor force, which could empower married women, is discouraged by the state's refusal to address the problem of women's being paid less than men for comparable work, to provide effective remedies for sexual harassment and . . . discrimination, or to subsidize child care alternatives for working mothers." (citations omitted)).

321. Debra Michaels, a women's studies professor at New York University, recently described the gendered formality of weddings: "Marriage is the big institution that maintains the status quo of the social order. It does it by tricking women, making them feel adored. From the time we're little girls, we're taught that our wedding day is going to be the biggest event of our lives." White, supra note 319. 
business equipment, intangible property, and other items essential to business and personal survival..$^{322}$ They can, moreover, do so without judicial intervention as long as they do not breach the peace. ${ }^{323}$ Secured creditors possess the additional clout of threatening to repossess in order to induce debtors to make decisions that serve the creditors' interests. These wide-ranging powers enjoyed by secured creditors exist largely because creditors have something that debtors want and presumably value: money, goods, and credit. In order to get these desired things, the debtor must be on his best behavior. If primary homemakers became secured creditors, the institutional change might inspire primary wage earners to treat their homemaking spouses with the same deference and respect with which debtors treat their creditors (at least to their faces) ${ }^{324}$ As a result, a husband might be more reluctant to hit or berate his wife if he understood the economic value of her contributions to family wealth..$^{325}$ On a more subtle level, perhaps both husbands and wives would more readily value primary homemaking if it had a liquidated value. ${ }^{326}$

These goals could be frustrated if spouses rejected the primary homemaker/primary wage earner paradigm. Spouses could opt out by participating equally in wage labor and homemaking. ${ }^{327}$ However, spouses who reject traditional roles to avoid commercializing their marriage could make as much headway toward dismantling patriarchy as PSAs would if fully enforced. If both spouses participate equally in wage labor and homemaking, then each spouse can support herself or himself, and thus has the power to leave the relationship at will. Such a fundamental

322. Article 9 does limit commercial creditors' rights in relation to consumer goods. Consumer goods are goods purchased primarily for personal, family, or household use. See U.C.C. § 9-109(1) (1995). A creditor, for example, cannot strictly foreclose on collateral that is consumer goods for which the consumer has paid $60 \%$ or more unless the consumer consents to the strict foreclosure. See id. § 9-505.

323. See id. § 9-503.

324. Some commentators might disagree, contending that importing market metaphors to the family disadvantages homemakers by marginalizing them even on their own turf. See Regan, supra note 26 , at $2310,2383-84$ (criticizing the disregard for the importance of traditional family norms created by the current market conceptualization of the relationship between former spouses after divorce). While Regan recognizes that "market considerations should play some role in determining what ex-spouses owe to each other," he resists it becoming "the predominant spirit of the marriage." Id. at 2387.

325. See Brinig \& Crafton, supra note 196 , at 894.

326. Tangible gendered power differentials exist in marriage based on differences in, for example, income, employment, and education and affect property division negotiations at the time of divorce. See Krauskopf \& Seiling, Pilot, supra note 58, at 183.

327. As in section III(A)(2), supra, a secured creditor must give value for the collateral in order for a security interest to attach. If neither spouse is primarily responsible for either homemaking or wage eaming, the security interest cannot exist, because both spouses would enjoy market role enhancement due to the other's homemaking and neither would suffer lost opportunity costs as a result of specializing in domestic labor. 
restructuring of both work and domestic labor would go a considerable distance toward the goals of many radical feminist scholars. ${ }^{328}$

Clearly, PSAs might not solve everything, but they are not worthless, either. ${ }^{329}$ Given the immensity of problems associated with gender inequality in marriage, PSAs seem worth a try. They offer some primary homemakers more security than they have now and may even make a dent in gender hierarchy.

The unprecedented confluence of diverse ideologies in support of PSAs may seem facile, particularly if one believes that traditionalist legal economics, and liberal, cultural, and radical feminism are separated by an unbridgeable ideological territory. However, the flexibility of PSAs draws on the unresolved empirical issues that are subject to differing assumptions under each ideological approach. For example, traditionalist legal economists believe that gendered specialization is biologically mandated, while liberal feminists perceive it as an artifact of female exclusion from the public realm. Moreover, cultural feminists may see specialization as culturally, but not biologically mandated, while radical feminists interpret the division of family and market as a way to construct specialization as natural. There is no way to anticipate precisely how PSAs might affect behavior. If traditionalist legal economic assumptions are correct, women would likely continue to specialize in homemaking. If liberal feminist assumptions are right, men and women would tend to divide homemaking and wage labor more equally. If cultural feminist assumptions prove correct, PSAs could effect some change in the dominant domestic ecology by affecting cultural forces that socialize women to specialize in homemaking. Finally, if radical feminist assumptions are correct, PSAs could be the hallmark of a new stage of state regulation of intimate relationships, based on economic considerations rather than reified gender roles. This diversity of likely outcomes under PSAs reflects the wide range of assumptions underlying different ideological approaches. PSAs' crossover potential lies in their ability to accommodate all of these assumptions; only by implementing PSAs could one determine which assumption would show itself to be most reflected in behavior. ${ }^{330}$

328. See, e.g., Williams, Coverture, supra note 6, at 2289-90 (articulating her goal of restructuring work and family life "to allow all workers, regardless of sex to be responsible workers and responsible adults simultaneously").

329. See MACKINNON, FEMINISM, supra note 30, at 116 ("Law is not everything in this respect, but it is not nothing either.").

330. Given the immensity of these assumptions and the nonessential nature of gender, women and men of different classes, races, and sexual orientations, for example, might respond differently to the incentives created by PSAs. Indeed, given the tremendous variety of identities other than gender that might impact the consequences of PSAs, it is likely that some or all of the alternative possibilities could come to pass. 
In sum, PSAs have much to offer to legal economic scholars and all strands of feminist scholars. Their versatility suggests that PSAs might provide the crossover appeal that no other proposal enjoys, although some critics would counter that items advertised as one-size-fits-all might more accurately be described as one-size-fits-no-one. Accordingly, the next Part addresses objections that legal economists and various feminists might raise regarding PSAs.

\section{One Size Might Fit No One}

\section{A. Legal Economic Skepticism}

While there are plenty of reasons for legal economists to support PSAs, they also might object to them on two grounds: (1) PSAs might create incentives for female opportunism; and (2) PSAs could conflict with biological imperatives to specialize on the basis of sex by encouraging specialization based on preference and skill, instead. Neither of these potential objections to PSAs, however, is sufficiently strong to outweigh the reasons for legal economic support for PSAs.

The first objection legal economists might have to PSAs turns on opportunism, a concept that examines the potential for primary homemaker, rather than wage earner, rent-seeking. This concern suggests that PSAs will give the primary homemaker an incentive to play her traditional role just long enough to have a child and then divorce her husband and live off thirty percent of the difference in their incomes until the child reaches majority (which could be as long as eighteen years). Moreover, these critics suggest that for couples without children, the wife could log enough years and then mooch off of the husband until the expiration of the one-year-of-support-for-every-two-years-of-marriage period of support for a childless marriage. ${ }^{331}$ Traditionalist legal economists would minimize this risk of homemaker opportunism given the way it conflicts with their view that women are biologically or culturally driven to specialize in domestic labor. These legal economists would assume that few women would invest their time in homemaking only for the percentage of the spouses' post-divorce income that the investment would yield. ${ }^{332}$ The dangers of homemaker opportunism diminish further when one considers

331. This criticism is a common response to income-sharing proposals. See, e.g., Krauskopf, Comments, supra note 225 , at $422-23$.

332. Reasonable economists likely would differ on this point. Some have suggested that marriage rates decrease when divorce laws do not protect women's traditional roles, which, in turn, suggests that female specialization in domestic labor may be more culturally than biologically driven. $C f$. Cohen, Rhetoric, supra note 53, at 2284 ("Whether for biological reasons, as I believe, or cultural reasons as many feminists believe, most women need no urging to nurture their children."). But see Silbaugh, Marriage, supra note 12 (manuscript at 91-93) (exploring the possibility that post-divorce income sharing could either encourage or discourage marriage). 
that in a marriage with children, the homemaker is unlikely to enjoy a free ride after divorce since she is still supporting the primary wage earner's status as an ideal worker by performing childcare tasks (and thus allowing him to be both a parent and an ideal worker at the expense of her own human capital). This analysis suggests that the dangers of homemaker opportunism under PSAs are minimal when the marriage has produced children. However, there may be more serious dangers of homemaker opportunism in a childless marriage.

The greatest level of opportunism would occur if a childless primary homemaker divorced to maximize her self-interest by being with another person or to leave homemaking for market labor. PSAs entitle her to thirty percent of the difference between her income and her primary wageearning spouse's income, but the total debt is limited by the years she invested. If she initiates divorce after five years (the typical time of divorce), ${ }^{333}$ she will get thirty percent of the difference between their incomes for two and one-half years. Moreover, childless marriages in which both spouses are employed are unlikely to generate tremendous payments. If, for example, a couple divorced after 6 years and made $\$ 50,000$ and $\$ 37,500$ respectively, ${ }^{334}$ then the lower-earning spouse will be entitled to $\$ 3750$ a year for 3 years, or a total debt of $\$ 11,250$. Assuming that the lower-paid spouse both did more than one-half of the housework and sacrificed her own human capital to accommodate the higher-paid spouse, this amount hardly seems exorbitant.

Even if the lower-paid spouse behaved badly toward the end of the marriage (through infidelity, for example), the fact remains that the primary wage earner probably benefitted from the primary homemaker's efforts during the marriage and thus should pay even if the circumstances of the divorce indicate that such payment seems unfair. ${ }^{335}$ If the primary

333. See BECKER, supra note 16 , at $327-28$ (noting that "about 40 percent of all divorces ... occur prior to the fifth year of marriage").

334. This figure is consistent with the average wage gap between men and women employed fulltime. See Lewin, supra note 6 (noting that the "median weekly earnings of full-time working women are just under 75 percent of the men's median" weekly wages).

335. Jurisdictions are split on the issue of whether to consider fault in making alimony determinations. See Timothy B. Walker \& Linda D. Elrod, Family Law in the Fifty States: An Overview, 26 FAM. L.Q. 319, 366-67 (1993). Those scholars who defend divorce law with moralitybased arguments may disagree with an approach that disregards marital misconduct. See, e.g., Carl E. Schneider, Moral Discourse and the Transformation of American Family Law, 83 MICH. L. REV. $1803,1809-11$ (1985). If this result jars some legal economists, they could argue that PSAs should be enforced under the rule of those states that take fault (especially adultery) into account in determining alimony and property division. See Ellman, Place, supra note 61, at 776-77 (stating that a number of states account for fault in property division or alimony); Karzenis, supra note 61, at 1121-24, 1129-35 (summarizing the law of fault-based support and property division). If both spouses are sufficiently independent from one another-if, for example, they married when they were both professionals employed full-time and contracted out their homemaking - then these two ideal workers could contractually waive their PSA rights and obligations. If their incomes were close enough, contracting around 
wage earner did not benefit from the efforts and sacrifices of his lower-paid spouse-if, for example, the higher-paid spouse did virtually all the housework and was the one sacrificing job opportunities to accommodate the other-then he could rebut the presumption that lower-paid spouses contribute to family wealth by shouldering a disproportionate share of homemaking responsibilities. Thus, PSAs present only limited risks of homemaker opportunism, which pale in comparison to the incentives for wage-earner opportunism under the current rules governing alimony.

The second objection that some legal economists might pose to PSAs stresses PSAs' potential to discourage gendered specialization of labor, which countermands the dictates of nature or culture. As already noted, traditionalist legal economists posit that such gendered specialization is biologically or culturally determined and efficient. ${ }^{336}$ Although PSAs might encourage women to specialize in domestic labor, they could also encourage men to specialize, or at least increase their participation, in homemaking. ${ }^{337}$ Accordingly, PSAs could encourage labor specialization based on personal preferences rather than sex. ${ }^{338}$ Over time, socialization patterns could change if PSAs induced men to increase the attention they devote to domestic work. ${ }^{339}$ If traditionalist legal economists are correct in asserting that gendered specialization of labor is biologically or socially compelled, then PSAs seem efficient in that they reward individuals for pursuing the path of least resistance. If, in the alternative, specialization is culturally malleable, then PSAs could encourage it or the basis of personal preferences and abilities rather than on sex. Either way, PSAs would promote efficiency. One spouse likely will still specialize in homemaking, but that person could be either male or female. ${ }^{340}$

In sum, even though some legal economists may have concerns about PSAs, a good number of economists would likely support the broader

the PSA would not be necessary because the debt due would be minimal given the near equality of their incomes.

336. See BECKER, supra note 16, at 39 (attributing gender specialization of labor to biological influences); Cohen, Best, supra note 26, at 2286, 2290 (attributing specialization to biology, or to culture); Ellman, Theory, supra note 11, at 47-49 (arguing that couples realize more satisfaction and wealth in traditional marriages).

337. See supra section IV(B)(2).

338. For example, some people might be better suited to specialize in domestic labor because they are patient with children, dislike working for wages, or otherwise prefer the domestic to the market sphere. It seems unlikely that these individuals would all be women, though certainly socialization could result in a majority of the people holding these preferences being female. See FucHS, supra note 6 , at $40-42$.

339. Nancy Chodorow suggests that gender patterns are based on the sex of primary childcare providers and implies that these patterns might change if men assumed more responsibilities for childcare. See CHODOROW, supra note 239, at 205-09.

340. See POSNER, ECONOMIC, supra note 16, at 156 (suggesting that in order for couples to maximize total household real income, one spouse should specialize in market-based employment and the other should focus on household production). 
proposition that commercializing marriage would deter opportunism. On the other hand, liberal, cultural, and radical feminists might oppose PSAs. However, as discussed in the next section, despite good reasons to scrutinize PSAs, feminist objections do not outweigh the benefits of PSAs.

\section{B. Liberal Feminist Skepticism}

Liberal feminism emphasizes both the importance of female participation in the wage labor force on the same terms as men and the equal treatment of men and women in almost all areas of law. ${ }^{341}$ Thus, liberal feminist scholars' primary objections to PSAs would likely emphasize that they are tailored to protect women who take traditional domestic roles, redirecting women away from full-time participation in the wage labor force.

It is true that PSAs would encourage some women to specialize in homemaking who might otherwise devote their primary attention to the work force. Moreover, PSAs could even encourage women to have more children, secure in the knowledge that upon divorce, the children will be provided for through the security interest. Given the inverse relationship between female fertility and participation in the wage labor force, ${ }^{342}$ PSAs' potential tendency to increase childbearing could squelch any equality feminist support it might have enjoyed otherwise. However, the premarital security interest may not offer enough financial support to change many women's preferences for market and domestic labor. As set out in Part III above, the primary homemaker's security interest secures a debt equal to thirty percent of the difference between the spouses' incomes, paid over a period equal to one-half the duration of the marriage plus the amount of time until the youngest minor child reaches majority. ${ }^{343}$ In 1996, the average high school educated man working full-time, year-round earned $\$ 30,709$ a year. ${ }^{344}$ On average, a high school educated woman working full-time, year-round earned $\$ 21,175 .{ }^{345}$ The wage gap is $\$ 9534$, and $30 \%$ of the difference between these amounts is $\$ 2860$. If this same primary homemaker did not work at all in the wage labor force, then she would be entitled to $30 \%$ of $\$ 30,709$, or $\$ 9212$, considerably less than she could earn through minimum wage labor. ${ }^{346}$ While this may encourage women with no market options to specialize in domestic labor, it is

341. See supra subpart IV(B).

342. See SHELTON, supra note 6 , at 55 (reporting that every child results in 1.24 fewer hours of paid labor per day to the mother).

343. See supra subsection II(A)(2)(a).

344. See CENSUS, INCOME, supra note 6, at 28 tbl.7.

345. See id. at 29.

346. The minimum wage is $\$ 5.15$. See 29 U.S.C. $\$ 206$ (a) (Supp. II 1996). For full-time, yearround work, a minimum wage worker grosses approximately $\$ 10,300$. MURPHY \& AZOFF, WAGE GUIDE, supra note 120 , at 29. 
unlikely to dissuade marketable women from entering and staying active in the wage labor force.

Liberal feminist analysts should also appreciate that men benefit and women bear the cost of the current system, which penalizes women and rewards men for taking traditional roles. The PSA, in contrast, imposes the cost of traditional gender roles upon men, which many liberal feminists would applaud considering that men currently benefit from traditional gender roles more than women. Moreover, imposing the cost of traditional roles upon men gives them the incentive to stray from traditional roles. Liberal feminism assumes that women have an incentive to resist traditional gender roles because the roles are subordinating and deprive them of choices. ${ }^{347}$ Men, however, need an incentive to resist traditional gender roles because giving up their traditional roles entails losing social privileges and economic advantages.

PSAs have the potential, paradoxically, to serve both of these ends of liberal feminism. By remunerating female domestic labor, PSAs make homemaking more like market labor, and thus decrease the prevalence of situations in which women's nonmarket activities contribute to the general devaluation of their work and personhood. Second, PSAs have the potential to encourage men to devote more attention to homemaking, which would contribute to the valuation of traditionally feminine labor and female participation in the wage labor force. Given that the demands of the workplace will not change until men, too, need significant time at home, PSAs have the potential to achieve the balance liberal feminism has long sought between the work men and women do in and out of the home. Therefore, it follows that liberal feminist scholars should appreciate PSAs despite PSAs' apparent support of traditional gender roles in marriage.

\section{Cultural Feminist Skepticism}

Cultural feminists seek to increase the social and economic value accorded to work traditionally done by women, such as homemaking. Because the bulk of the discussion regarding post-divorce income sharing can be characterized as either cultural feminist or legal economic, it is particularly important to understand and address any cultural feminist objections to PSAs. Specifically, PSAs might conflict with cultural feminist concerns in at least four ways: (1) PSAs might overshadow important noncommodifiable functions of family; (2) PSAs might not help the poorest displaced homemakers in that their former spouses are likely to be equally indigent; (3) PSAs might create incentives for men not to marry in order to evade the security interest; and (4) PSAs might push women into the 
workforce who prefer to specialize in domestic labor. This subpart addresses each of these objections, in turn.

1. Commodification Anxiety.-There are important cultural feminist objections to reducing family life to emotionless commercialized concepts of investment in marital enterprises and human capital. Ann Estin, for example, expresses a strong "concern not to commercialize marriage," 348 and Nancy Staudt worries that taxing housework to entitle women to government benefits might impose the "demeaning effects of the market" on women who specialized in homemaking in order to evade the market and its tendency to reduce people to "abstract fungible unit[s]."349 Regan similarly cautions that market rhetoric applied to the family capitalizes on the hierarchy of market over family activity, and that it will further marginalize caregivers through its norms of autonomy, obligation, and economic inequality. ${ }^{350}$ Joan Williams labels this fear "of a world in which all human relations assume a market model of commercialized selfseeking" as "commodification anxiety." ShI She contests "a reflexive anticommodification posture" on the grounds that much market labor involves interpersonal elements just as homemaking labor includes economic elements, and that feminist commodification anxiety paradoxically tends to ratify existing gender hierarchy:

Once we acknowledge the nonmarket aspects of market transactions and the role of the market in intimate behavior, family relations can be seen as giving rise to economic entitlements without awakening the fear that all intimacy and caring will be replaced by instrumental behavior. . . . The commodification debate must evolve away from a reflexive anticommodification posture, to an understanding of the way commodification anxiety polices traditional gendered allocations and maintains the dichotomy between the market and the family. ${ }^{352}$

Katharine Silbaugh persuasively contends in the same vein that feminists miss crucial opportunities to value the work women do for their families when they reject economic methodologies for valuing that

348. Estin, Love, supra note 26, at 1062. Estin seems concerned that commercializing marriage will somehow jeopardize the personhood of family members in its eagerness to transform "the messy, flesh and blood reality of marriage and family life" into "cleaner, simpler, more manageable forms." Id. at 1065; see also Margaret Jane Radin, Market Inalienability, 100 HARV. L. REV. 1849, 1885 (1987) [hereinafter Radin, Market] (arguing that "universal market rhetoric does violence to our conception of human flourishing"); Williams, Coverture, supra note 6, at 2275 (noting that "commercial analogies ... seem jarring and out of place when applied to family relations").

349. Staudt, supra note 141, at 1631 (quoting Radin, Market, supra note 348, at 1885).

350. See Regan, supra note 26 , at 2309-10.

351. Williams, Coverture, supra note 6, at 2277. For further discussion of feminist discomfort with commodification, see Silbaugh, Commodification, supra note 171, at 84-86, 90-95.

352. Williams, Coverture, supra note 6, at 2282. 
work. ${ }^{353}$ Commercializing marriage through PSAs accepts Silbaugh's and Williams's invitations to transcend commodification anxiety to intervene in current allocations of gendered power in marriage. Any cultural feminist commodification anxiety elicited by the fact that PSAs are explicitly modeled on commercial security agreements might be alleviated by an understanding that the very effort to remunerate homemaking is necessarily an economic, financial enterprise. The primary homemaker may initially be motivated by love when she extends credit to her spouse in order to facilitate the spouse's attainment of ideal worker status; her experience of intimacy is informed by an expectation that the intimacy will last long enough for the homemaker to get a return for her efforts and sacrifices. However, when the marriage ends, the love evaporates, leaving only economic issues to reconcile. ${ }^{354}$ In short, any model which remunerates homemaking labor will run into commodification problems. If objections to commodification prevail, then the pervasive problem of displaced homemaker indigency (and its underlying gender inequities) will remain unaddressed.

Cultural feminist concerns with the commodification inherent in commercializing marriage through PSAs might be allayed by recognizing that PSAs merely reveal the commercial aspects of marriage that masquerade as being only about love. The PSA would constitute just one aspect of a varied and complex marital relationship. ${ }^{355}$ Margaret Radin points out "both commodification and noncommodification may be harmful" to women, and she suggests a pragmatic approach that asks which one is better for women in a particular circumstance. ${ }^{356}$ Most people do not think that their marriage will dissolve, so they never learn the details of divorce law. ${ }^{357}$ Thus, the love, obligation, dependency, and sacrifice central to a cultural feminist understanding of family would not be tainted by commercializing marriage through PSAs because they only affect one

353. See Silbaugh, Commodification, supra note 171 , at 83-84, 99-109, 120-21.

354. Indeed, with the notable exceptions of child custody arrangements and domestic violence issues, perhaps the state is only capable of addressing financial issues.

355. There is little reason to anticipate that PSAs would change the empty-head-full-heart state in which most people get married; even if they knew about and understood PSAs, spouses likely would either think that they would never have to worry about them because their marriage would last, or that post-divorce alimony is typical. See Baker \& Emery, supra note 145, at 442-43 (reporting that people applying for marriage licenses are aware of divorce rates but believe they will not get divorced, and that they overestimate the likelihood of alimony awards). Moreover, there is little reason to think that commodifying one aspect of marriage would contaminate every other noneconomic aspect. See Silbaugh, Commodification, supra note 171, at 99 (arguing that "the emotional account of human labor does not disappear in the face of the economic account").

356. Margaret Jane Radin, The Pragmatist and the Feminist, 63 S. CAL. L. REv. 1699, 1700 (1990).

357. See Baker \& Emery, supra note 145 , at $442-43$. 
part of marriage, the financial aspects, and may not even affect many of the spouses' interactions during the marriage. ${ }^{358}$

2. Applicability to Poor Homemakers.-Another potential cultural feminist objection to PSAs is that they fail to remedy the most extreme cases of displaced homemaker indigency and primarily benefit middle- and upper-middle-class women. ${ }^{359}$ Given race-based differences in wealth, ${ }^{360}$ this bias would have race and class implications. This critique hinges on three assumptions underlying PSAs: (1) the dominant domestic ecology is composed of a primary wage earner and a primary homemaker; (2) the primary wage earner is an ideal worker with a sufficiently high income that a percentage of it would be of use to his former spouse; and (3) even when both spouses work, there is a large gap between the wages of men and women. ${ }^{361}$

Contrary to these assumptions, the dominant domestic ecology, which serves as the basis for PSAs, does not adequately describe many marriages of low-income spouses who do not have the option to drop out of the wage labor market to devote primary attention to homemaking. ${ }^{362}$ Nor does it describe many marriages involving people of color, as there is a smaller gap between the wages of men and women of color than between white men and women. ${ }^{363}$ Finally, many poor women marry men who are also poor, ${ }^{364}$ calling into question the relevance of income sharing when there is almost no income to share. This disconnection between theories of alimony and the concerns of women of color is particularly troubling because these women receive alimony awards even less often than white women. ${ }^{365}$ For these reasons, critics could accuse PSAs of catering only

358. See Silbaugh, Commodification, supra note 169, at 99. But see supra Part IV (suggesting the various ways that PSAs might influence marital conduct).

359. See Perry, Alimony, supra note 13, at 57 \& n.17.

360. See Regina Austin, Nest Eggs and Stormy Weather:Law, Culture, and Black Women's Lack of Wealth, 65 U. CIN. L. REv. 767, 769-70 (1997) (explaining that in 1993, white households had a median net worth of $\$ 45,740$, while the figure dropped to $\$ 4418$ for black households).

361. See supra subpart III(A).

362. See CENSUS, INCOME, supra note 6 , at 27 tbl.7.

363. See FuCHS, supra note 6, at 50 (describing how in 1980 black and white women earned roughly the same amount of money, and the adjusted differential between black and white men was less than half the difference between white men and white women); see also CENSUS, INCOME, supra note 6 , at $26-27$ tbl.7 (reporting that the income gap between white men and women is $\$ 21,780$, while it is only $\$ 4719$ between black men and women); Brown, supra note 13, at 793 (describing a 1990 study indicating that married African-Amercian women contribute about $40 \%$ of family income).

364. See Diane K. McLaughlin \& Daniel T. Lichter, Poverty and the Marital Behavior of Young Women, 59 J. MARRIAGE \& FAM. 582, 584 (1997) (suggesting that poor women are less likely to marry economically attractive men because of trends in increasing homogamy by education and employment, and poor women's isolation in poor communities).

365. See Perry, Alimony, supra note 13, at 2483 (describing 1987 Census Bureau statistics demonstrating that $18 \%$ of white women were awarded alimony, compared to less than $8 \%$ of AfricanAmerican women). 
to privileged women, or worse, of ratifying the privilege of those women over poor women and many women of color. ${ }^{366}$ Many cultural feminists suggest that these flaws in theories justifying post-divorce income sharing make state support of homemaking preferable. ${ }^{367}$ This powerful argument requires serious attention.

Some of these concerns cannot be rectified by any proposal that justifies post-divorce income sharing. By definition, post-divorce income sharing involves redistributing wealth between two private parties and determines the value of homemaking based on the homemaker's relationship to a primary wage earner. ${ }^{368}$ It is not surprising, therefore, that Fineman focuses on public assistance, because this is the major alternative to redistribution between spouses. However, Fineman's proposal has pragmatic problems given the current climate of extraordinary hostility toward public assistance. ${ }^{369}$ It could be that most or all post-divorce incomesharing paradigms will benefit white, middle- and upper-middle-class women more than poor women and many women of color. In spite of this generalization, PSAs, like other modern justifications for alimony, would also benefit many middle-class women of color, and could also make a difference in the post-divorce finances of working-class primary homemakers.

In addition, PSAs could benefit many low-income women if the debt secured by PSAs were treated as a marital debt. If, for example, there were more debts than assets in a divorce, the debt secured by the PSA could be a setoff, resulting in the primary homemaker bearing less of the debt liability than her spouse. ${ }^{370}$ Moreover, PSAs could benefit many low-income women who earn their living through domestic work in other people's homes if the economic and social valuation of homemaking resulted in a general increase in the wages for domestic work. ${ }^{371}$

366. See id. at 2484 (suggesting that theories of alimony based on a paradigmatic white middleor upper-middle-class marriage "reinforce the subordination and marginalization of Black women . . . by reinforcing privilege . . . and second, by reinforcing a hierarchy among women in which their value is determined by the presence or absence of legal ties to men, particularly affluent men"); Roberts, supra note 43, at 51-52, 80 (describing a divide between spiritual and menial housework that disadvantages poor women and many women of color, concluding that "[o]ur future struggles for an equitable approach to housework must center on the fight for economic justice and social support for the women who have been labeled fit for menial but not spiritual work").

367. See, e.g., FINEMAN, NEUTERED, supra note 35, at 232-33.

368. See supra subpart III(A).

369. See supra note 43 and accompanying text.

370. Nancy Staudt makes a similar suggestion in her proposal to tax housework and create a household income tax credit. See Staudt, supra note 141, at 1631.

371. See Roberts, supra note 43, at 51-52 (contending that the dichotomy of spiritual and menial housework contributes to a devaluation of the latter and attendant low wages for the women who perform it). 
3. Male Marriage Resistance.-The third cultural feminist objection to PSAs stems from the possibility that some men could rebel against the financial obligations PSAs impose by refusing to marry. ${ }^{372}$ If they did, women in relationships with those men would be even more financially vulnerable than they are now, as they would not enjoy the considerable benefits that come with marriage, such as social security payments and other government programs that require marriage as a precondition to participation. ${ }^{373}$

Four considerations prevent the risk of male marriage resistance from being a serious concern. First, as previously discussed, many men may still marry despite the PSA, either because they think that they will stay married and it will not apply to them, or because the PSA is just one factor in a much bigger decision of whether to marry. ${ }^{374}$ Second, marriage rates are decreasing anyway (some would say because current marriage laws do not sufficiently protect women). ${ }^{375}$ Third, even if PSAs did result in male marriage resistance, cultural feminists should appreciate the way in which this pattern could result in an increased focus on the value of mothering and decreased focus on the marital relationship. ${ }^{376}$ The fourth, and perhaps strongest, response is that this argument could be raised against any marriage rules protecting women, just as opponents of antidiscrimination employment laws argued that those laws would deter employers from hiring people of color or white women. ${ }^{377}$ In sum, the

372. Katharine Silbaugh anticipates and refutes this objection to her proposal that courts not enforce premarital contracts that limit alimony or property division. See Silbaugh, Marriage, supra note 12 (manuscript at 91-93) (countering this critique by contesting its factual basis and questioning its importance).

373. See Cynthia Grant Bowman, A Feminist Proposal to Bring Back Common Law Marriage, 75 OR. L. REV. 709, 711 (1996) (providing anecdotal evidence of women in long-term relationships unable to utilize laws protecting widows (citing GLENDON, supra note 68, at 5)). Bowman argues for reinstating common-law marriage to protect women who are vulnerable to both poverty and abuse from their intimate partners. See id. at 779-80. This proposal goes a long way toward remedying any concerns of women's increased vulnerability caused by male marriage resistance. However, the fact that only twelve jurisdictions currently recognize common-law marriage, $i d$. at 715 , indicates that, for the time being, formalized marriage is a more likely source of economic protection for many women.

374. See supra section $\mathrm{V}(\mathrm{C})(1)$.

375. See FinEMAN, IlluSiON, supra note 26, at 89-91; Silbaugh, Marriage, supra note 12 (manuscript at 92) (arguing that the inability to enforce nonmonetary premarital agreements may have discouraged marriages). Marriage rates could also be decreasing as the gay rights movement continues to lead many gay people to come out earlier than they would have in the past, thereby increasing the population of never-heterosexually-married people. See Kris Franklin, 'A Family Like Any Other Family': Alternative Methods of Defining Family Law, 18 N.Y.U. REV. L. \& SOC. CHANGE 1027, 1043 (1990-91) (correlating the gay rights movement with increased divorce rates). If, however, PSAs did result in male marriage resistance, this effect might be exacerbated by already-falling marriage rates.

376. See, e.g., FINEMAN, NEUTERED, supra note 35, at 228-33.

377. See Jerome McCristal Culp, Jr., Neutrality, the Race Question, and the 1991 Civil Rights Act: The "Impossibility" of Permanent Reform, 45 RUTGERS L. REV. 965, 985 (1993) (criticizing the argument that civil rights protections deter employers from hiring people of color). 
cultural feminist concern regarding male marriage resistance is unwarranted. ${ }^{378}$

4. Forced Labor.--The fourth and final cultural feminist objection to PSAs suggests that PSAs might frustrate the desires of many married women who want to be primary homemakers. ${ }^{379}$ PSAs could cause their husbands to push them into the labor market, making them work the infamous second shift. ${ }^{380}$ This effect would be particularly burdensome for those women of color who may view primary homemaking and mothering as opportunities to resist oppression by serving their own families rather than others and to prepare their children to survive in a racially hostile world. ${ }^{381}$ There are several responses to these contentions.

First, the stark choice between wage and homemaking labor is a false one; being a full-time homemaker is a luxury that most women cannot afford. ${ }^{382}$ Second, both full- and part-time homemakers would desire remuneration for their work in the home. Third, many women may be willing to increase their market labor in return for increased male participation in domestic work. ${ }^{383}$ Accordingly, PSAs would not necessarily push women to do work for wages more than they want to, and may

378. This Article focuses only on marriage as the simplest way to implement the security agreement and thus to value a primary homemaker's contribution to her primary wage-earning spouse's income. It could, however, easily be adapted to nonmarital relationships, heterosexual or gay. Such an application likely would be similar to that associated with common-law marriages, or a domestic partnership set of criteria (such as cohabitation, shared finances, and intent to remain in the relationship). It could, of course, also be introduced via contract into either marital or nonmarital relationships. For further discussion of PSAs as applied to gay men and lesbians, see Martha $M$. Ertman, Reconstructing, supra note 231 (manuscript at 46-50).

379. As West noted:

[N]either liberal nor radical feminist legal critics have committed themselves to the task of determining the measure of women's happiness or suffering .... The cost to women of feminist legal theorists' endorsement of the anti-phenomenological methodology and anti-hedonic norms of the models they endorse is very high. It renders liberal and radical feminist legal theorists peculiarly uncritical-as feminists-of the visions of the human and thus of the normative assumptions of the models for legal criticism which they have respectively embraced.

Robin West, The Difference in Women's Hedonic Lives: A Phenomenolog:cal Critique of Feminist Legal Theory, 3 WIS. WOMEN's L.J. 81, 87-89 (1987).

380. See generally HocHSCHILD, supra note 6, at 6-10.

381. See Perry, Alimony, supra note 13, at 2490-92 (discussing some differences in the attitudes of African-American and white women regarding full-time homemaking).

382. See FinEMAN, ILLUSION, supra note 26, at 47 ("F]ull-time housewives are an economically elite group.").

383. Contrary to some scholars' contention that women seek financial resources in a mate while men seek physical attractiveness, a recent study indicates that women value altruism, agreeableness, and kindness as much as social dominance. See Lauri A. Jensen-Campbell et al., Dominance Prosocial Orientation, and Female Preferences: Do Nice Guys Really Finish Last?, 68 J. PERSONALITY \& SOC. PsYCHOL. 427, 437-39 (1995); see also Malcolm Ritter, Money Really Can't Buy Love, RoCKY MOUNTAIN NEWS, Aug. 12, 1996, at 21A. 
well encourage a balance of wage and homemaking work that many women might prefer to the dominant domestic ecology.

In sum, cultural feminist concerns about PSAs accompany any postdivorce income-sharing proposal and are not as serious as they initially appear. Therefore, cultural feminist opposition should not prevent adoption of PSAs across ideological spectrums.

\section{Radical Feminist Skepticism}

The final ideological position that might challenge PSAs is radical feminism. Because it advocates the complete restructuring of gender roles, radical feminist opposition to PSAs would likely focus on the way that PSAs depend on and support marriage. ${ }^{384}$ As such, PSAs arguably are instruments of compulsory heterosexuality ${ }^{385}$ because they might encourage women to maintain their traditional roles, commodify the homemaking of only married women, and value it based on the man's income. In short, a radical feminist response to PSAs could condemn them as part and parcel of "the heterosexual imperative." 386 Even if PSAs increased male participation in childrearing (and female participation in the wage labor force), radical feminists might still contest them as unsuited for dismantling patriarchal power structures, as childcare might then become valued and women's work remain uncommodified. ${ }^{387}$ While these are compelling arguments, other strategic possibilities inherent in PSAs could outweigh them. Radical feminist opposition to PSAs depends upon the analysis of the diverse effects PSAs could have on the dominant domestic ecology.

First, PSAs might undermine the dominant domestic ecology by causing men to increase their contributions to domestic work and women to increase their participation in the paid labor force. Altering gender within marriage could then change gender beyond marriage. Commercializing marriage through PSAs could, for example, lead to state recognition of any intimate relationship involving the mingling of assets and liabilities (e.g., gay and lesbian relationships). Radical feminist commentators might appreciate any measure that could contribute to lifting the ban on gay marriage because the ban is based on a highly gendered construction of marriage. $^{388}$ If, moreover, PSAs encouraged spouses to specialize in

384. See, e.g., Rich, Compulsory, supra note 298, at 228 (asserting that traditional institutions of "compulsory heterosexuality," such as heterosexual marriage, are instruments of control that undermine the political power of women).

385. See id. at 232.

386. BUTLER, BODIES, supra note 35 , at 2 .

387. See Rich, Compulsory, supra note 298, at 232 ("I believe large numbers of men could, in fact, undertake child care on a large scale without radically altering the balance of male power in a male-identified society.").

388. See supra subpart II(A) for a discussion of how an understanding of marriage as highly gendered informed the Defense of Marriage Act. 
domestic or market labor based on ability or preference rather than sex, gender would be associated less strongly with biological sex. They thus add credence to Butler's theory of gender performativity by separating gender from sex.

In the alternative, radical feminists could appreciate PSAs even if they caused women to remain primary homemakers in most marriages. In these cases, PSAs would still remunerate caregiving upon divorce. Additionally, once PSAs were in effect long enough to generate commentary in mainstream discussions, they might contribute to equalizing the balance of power during marriage. This application of market roles to women in a domestic setting nicely harnesses the commodification of power in women's favor. A radical feminist would likely at least smile appreciatively at the notion of a market of people armed to repossess equipment and inventory, and able to facilitate garnishment of accounts receivable or income for their homemaker clients. This inversion-from powerless homemaker to powerful secured creditor, from domestic victim to commercial profit maximizer-is enough to win the support of many radical feminists.

Third, radical feminists would support PSAs because they need not be restricted to married parties. It would be easiest to implement PSAs in marriage, as the lack of solemnization or state registration in most other heterosexual (or gay) relationships would make it difficult to determine the time at which the PSA arose. However, other formalizations of relationships, such as domestic partnership registries, might fill part of this gap. ${ }^{389}$ Domestic partnership registration could be publicly recorded to provide subsequent creditors with notice, and thus they could create a domestic security interest under which the primary homemaking partner would have a security interest in the other partner's post-separation stream of income. While radical feminists could critique the way that domestic partner registries mimic heterosexual marriage (requiring, for example, that the partners be not married or partnered already, or consanguineous), ${ }^{390}$ radical feminist theory could also support domestic partnership registration as an alternative to marriage and thus a vehicle for cleansing the legal regulation of intimate relations of misogynist roots. ${ }^{391}$

389. A number of states and municipalities extend some form of benefits to domestic partners. See LAMBDA LEGAL DEFENSE AND EDUC. FuND, INC., DOMESTIC PARTNERSHIP RECOGNITION AND BENEFITS: A NATIONAL OVERVIEW 3 (1997).

390. Hawaii's recently enacted partnership legislation is a remarkable departure from this general pattern. That legislation allows any two people not able to legally marry (including blood relatives) to designate each other as reciprocal beneficiaries and thus share the significant benefits associated with insurance, inheritance, and other areas traditionally limited to legal spouses. See HAW. REV. STAT. ANN. § 572C (Michie Supp. 1997).

391. See Paula L. Ettlebrick, Legal Marriage Is Not the Answer, HARV. GAY \& LESBIAN REV., Fall 1997, at 34, 34 (criticizing the push for same-sex marriage as robbing "ourselves of an important opportunity to challenge heterocentric sexual and family hierarchies"). 
In sum, commercializing marriage through PSAs does not resolve every possible concern and may help some women more than others. However, no single criticism outweighs their potential to serve the interests of a wide variety of ideological approaches in addressing the twin problems of displaced homemaker indigency and the devaluation of women's work. Despite valid concerns that could be raised by legal economists, as well as liberal, cultural, and radical feminists, PSAs have the unique potential to achieve consensus among a myriad of divorce reform proposals.

\section{The Procedural Potential of Premarital Security Agreements}

This Article has argued that PSAs have the potential to achieve the crossover appeal that no other contemporary justification for alimony has achieved. Yet, as previously discussed, various ideological difficulties might pose a barrier to embracing PSAs. Ultimately, even if the PSA fails to win universal support as a substantive tool for implementing and justifying alimony, it still has significant value as a procedural device to implement another proposal for valuing homemaking labor.

Both Starnes's partnership model and Ellman's financially rational sacrifices proposal could use PSAs as a method to implement their substantive proposals. Under Starnes's partnership model, the primary homemaker would have a buyout right that PSAs could protect. ${ }^{392}$ PSAs could also provide primary homemakers with a self-help remedy to collect the primary wage earner's buyout payment. Similarly, Ellman's remuneration for human capital losses due to marital-sharing behavior could be enforced through PSAs. PSAs could, furthermore, be one of the statutory options that Stake proposes spouses could select from the menu of rules governing dissolution, alimony, and property distribution. ${ }^{393}$ In this manner, PSAs could go some distance toward equalizing the parties' relative financial health after divorce and also import a highly developed doctrinal scheme to value homemaking into family law.

A second alternative to full statutory adoption of PSAs is to incorporate them into pre- or post-marital contracts, or relationship contracts of couples who do not or cannot marry. ${ }^{394}$ Contractually creating the PSA would provide a means for couples to choose to remunerate homemaking labor (and attendant sacrifices) ${ }^{395}$ and might also pave the way for statutory adoption if spouses and attorneys found that they worked well. ${ }^{396}$

392. See supra subsection IV(C)(1)(c).

393. See Rasmusen \& Stake, supra note 27, at 495-96.

394. See Ertman, Reconstructing, supra note 231 (manuscript at 49-50); Stake, supra note 27, at 453-54 (providing a sample premarital agreement form).

395. Courts might, however, shy away from enforcing contractual PSAs. See Silbaugh, Marriage, supra note 12 (manuscript at 6).

396. Cf. Martha M. Ertman, Contractual Purgatory for Sexual Marginorities: Not Heaven, But Not Hell Either, 73 DENV. U. L. REV. 1107, 1137-39, 1167 (1996). 
Whether the commercialization of marriage is substantive or procedural, statutory or contractual, PSAs significantly contribute to addressing the problems of displaced homemaker indigency and the general devaluation of women's work.

\section{Conclusion}

Commercializing marriage through premarital security agreements has the potential to address two seemingly intractable problems of family law and feminism by commodifying primary homemakers' contributions to family wealth and increasing the value of women's work generally. PSAs make sense because they import a solution from one private realm (the market) and apply it to another private realm (the family) in order to solve an essentially financial problem. Modeled on commercial security agreements, PSAs recognize the debtor-creditor elements of the spousal relationship in a traditional marriage, and accordingly grant primary homemakers a security interest in fifty percent of all marital property (including the primary wage earners' post-divorce income). The homemaker extends credit to her primary wage-earning spouse in the form of unremunerated homemaking services and lost opportunity costs that enable the primary wage earner to participate fully as an ideal worker in the labor market. The debt is calculated based on the difference between the spouses' incomes at divorce, the length of the marriage, and the age of any children. PSAs build on other proposals justifying post-divorce income sharing and have the unique potential to win support from diverse ideological approaches.

In particular, PSAs satisfy many concerns of legal economic as well as liberal, cultural, and radical feminist approaches. PSAs serve the legal economic goals of efficiency and deterring opportunism in marriage, and they also serve the cultural feminist goal of increasing the social and economic value of caretaking work. While liberal feminist concerns are likely to arise because of PSAs' potential to create incentives for women to adopt traditional gender roles in marriage, liberal feminists should appreciate PSAs' parallel potential to create incentives for more equal distribution of homemaking and wage-labor in marriage. Despite the anticipated resistance of radical feminists to PSAs' apparent support for traditional gender roles in marriage, PSAs serve radical feminist interests by transforming the cultural category of economically vulnerable housewife into a powerful market player, the secured creditor. In sum, PSAs may have crossover analytical appeal as a solution to the problems of displaced homemaker indigency and the general devaluation of women's work.

Although no single proposal may satisfy every ideological approach, the objections of each of these approaches can be addressed and largely overcome. Furthermore, even if one or more ideological approach rejects 
PSAs, PSAs could still serve as a procedural tool for implementing other proposals for post-divorce income sharing, or be included in marital or relationship contracts.

Overall, PSAs have both practical and theoretical benefits. On a practical level, commercializing marriage could significantly diminish the economic hardship of divorce on displaced homemakers and their children. On a theoretical level, PSAs may contribute to the evolving social redefinition of gender, and, in doing so, may alter the current low valuation of women's work. If PSAs achieve these lofty goals, they could change the way society thinks about caretaking work and women's labor in general. Commercializing marriage through PSAs has the potential to alleviate the seemingly intractable problems of displaced homemaker indigency and the devaluation of women's work by importing often-overlooked models from the market to address financial inequities in family law. 